Nevada

Environmental

Restoration

Project

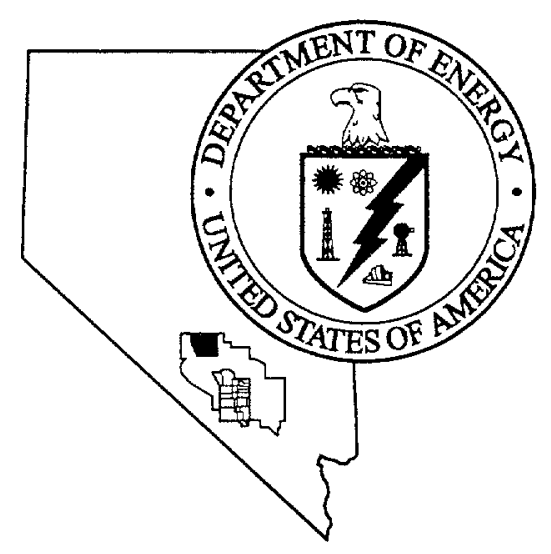

Corrective Action Plan for Corrective Action Unit 407: Roller Coaster RADSAFE Area, Tonopah Test Range, Nevada

Controlled Copy No.

Revision: 0

May 2000

Environmental Restoration

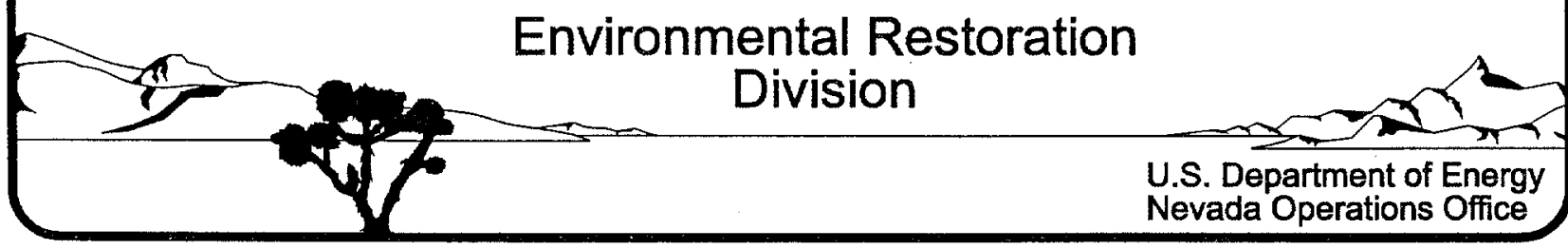




\section{DISCLAIMER STATEMENT}

Reference herein to any specific commercial product, process, or service by trade name, trademark, manufacturer, or otherwise, does not necessarily constitute or imply its endorsement, recommendation, or favoring by the U.S. Government or any agency thereof or its contractors or subcontractors.

\section{AVAILABILITY STATEMENT}

Available for sale to the public from:

U.S. Department of Commerce

National Technical Information Service

5285 Port Royal Road

Springfield, VA 22161-0002

Telephone: 800-553-6847 or 703-605-6000

Fax: 703-605-6900

E-mail: orders@ntis.fedworld.gov

Online ordering: http://www.ntis.gov/ordering.htm

Available electronically at http://www.doe.gov/bridge

Available for a processing fee to U.S. Department of Energy and its contractors, in paper, from:

U.S. Department of Energy

Office of Scientific and Technical Information

P.O. Box 62

Oak Ridge, TN 37831-0062

Telephone: $865-576-8401$

Fax: 865-576-5728

E-mail: reports@adonis.osti.gov 


\title{
CORRECTIVE ACTION PLAN FOR CORRECTIVE ACTION UNIT 407: ROLLER COASTER RADSAFE AREA, TONOPAH TEST RANGE, NEVADA
}

\author{
Prepared for \\ U. S. Department of Energy \\ Nevada Operations Office \\ Work Performed Under Contract No. \\ DE-AC08-96NV11718
}

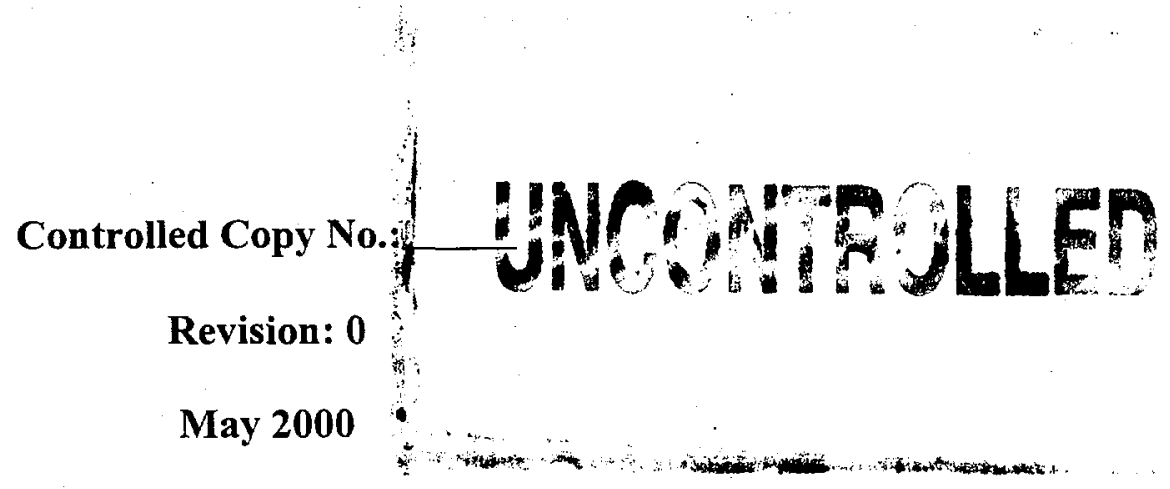




\section{THIS PAGE INTENTIONALLY LEFT BLANK}

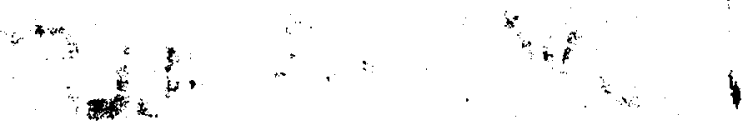

$+$ 


\section{CORRECTIVE ACTION PLAN FOR CORRECTIVE ACTION UNIT 407: ROLLER COASTER RADSAFE AREA, TONOPAH TEST RANGE, NEVADA}
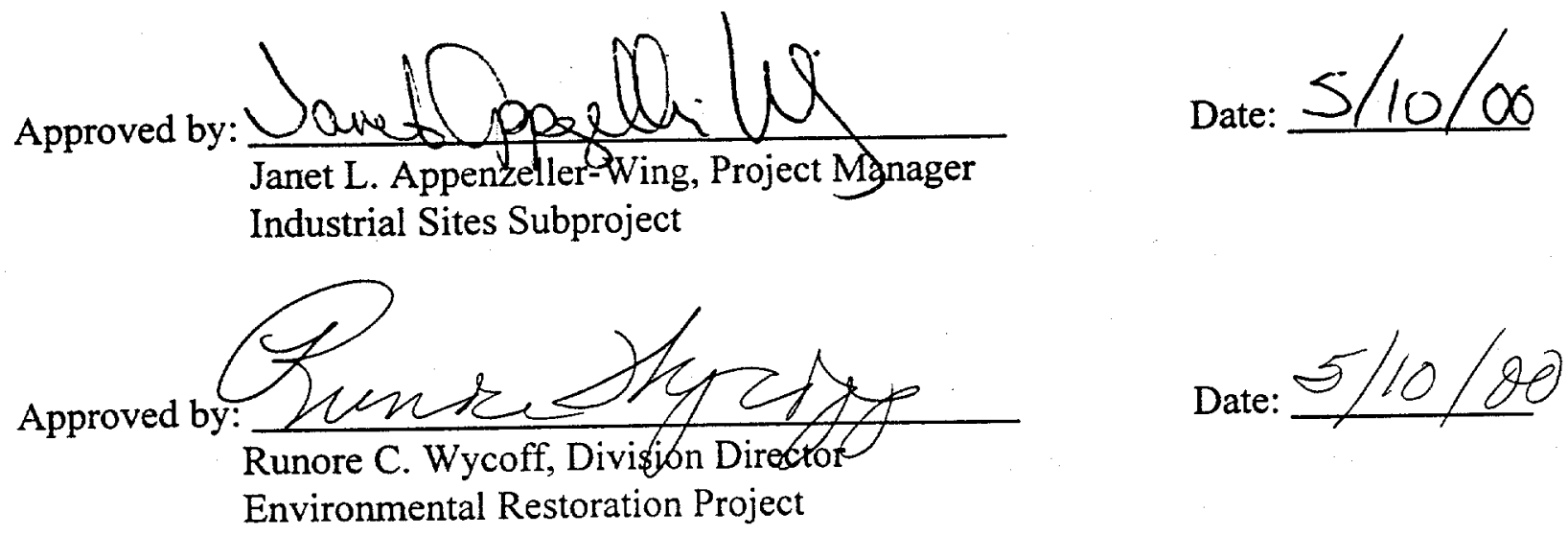

iii 


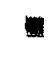

$\mathbf{a}$

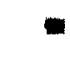

THIS PAGE INTENTIONALLY LEFT BLANK

. 


\section{TABLE OF CONTENTS}

ACRONYMS AND ABBREVIATIONS $\ldots \ldots \ldots \ldots \ldots \ldots \ldots \ldots \ldots \ldots \ldots \ldots \ldots \ldots$ vii

EXECUTIVE SUMMARY $\ldots \ldots \ldots \ldots \ldots \ldots \ldots \ldots \ldots \ldots \ldots \ldots \ldots \ldots \ldots \ldots \ldots$ viii

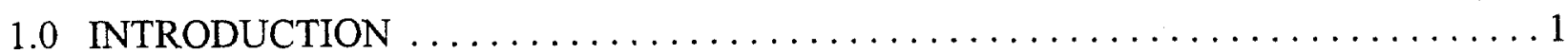

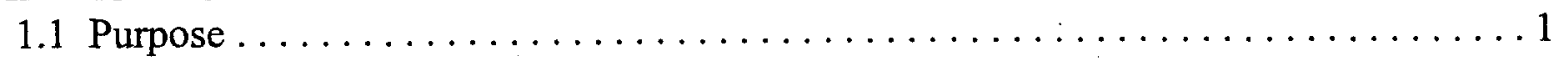

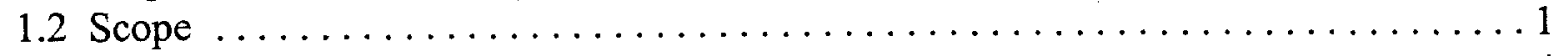

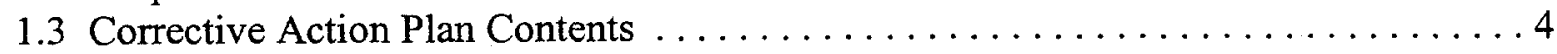

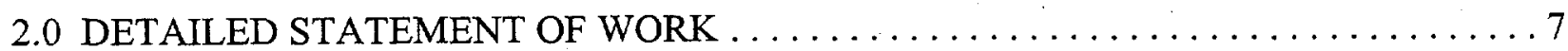

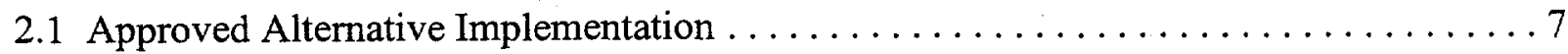

2.1.1 Preplanning and Site Preparation . . . . . . . . . . . . . . . . . . . . 7

2.1.1.1 Site-Specific Health and Safety Plan/Hazard Analysis $\ldots \ldots \ldots \ldots \ldots \ldots 7$

2.1.1.2 Field Management Plan . . . . . . . . . . . . . . . . . . . . . . 7

2.1.1.3 National Environmental Policy Act Documentation $\ldots \ldots \ldots \ldots \ldots \ldots 8$

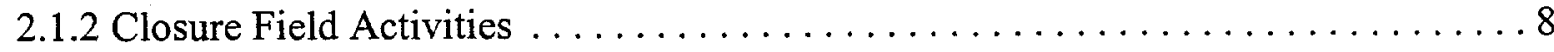

2.1.2.1 Removal of Surface Impacted Soils $\ldots \ldots \ldots \ldots \ldots \ldots \ldots \ldots \ldots \ldots \ldots$

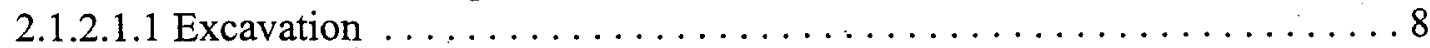

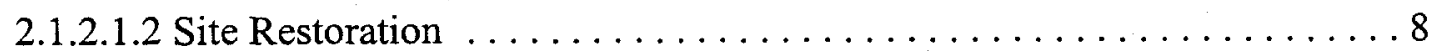

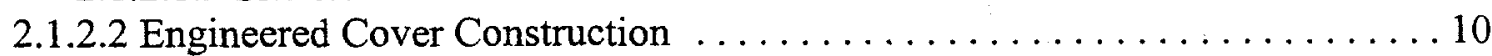

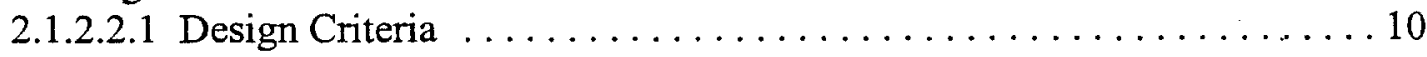

2.1.2.2.1.1 Run-on/Runoff ............................. 10

2.1.2.2.1.2 Consolidation $\ldots \ldots \ldots \ldots \ldots \ldots \ldots \ldots \ldots \ldots \ldots \ldots \ldots \ldots \ldots$

2.1.2.2.1.3 Maintenance and Repair ........................ 11

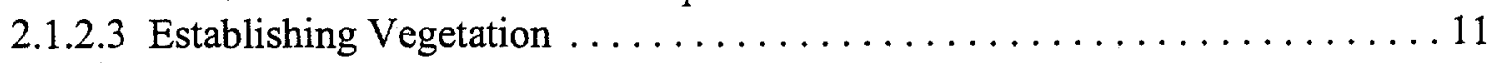

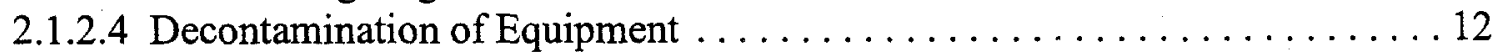

2.2 Construction Quality Assurance/Quality Control $\ldots \ldots \ldots \ldots \ldots \ldots \ldots \ldots \ldots \ldots \ldots$

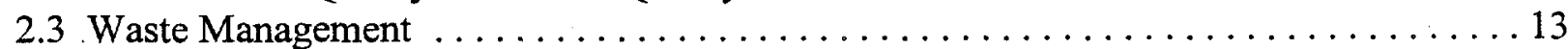

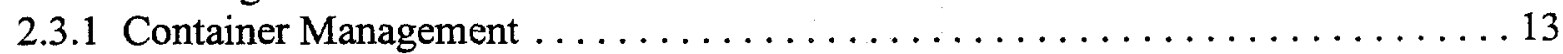

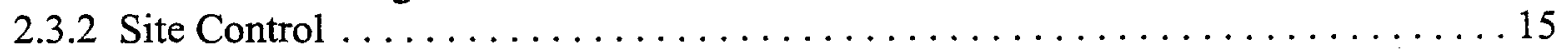

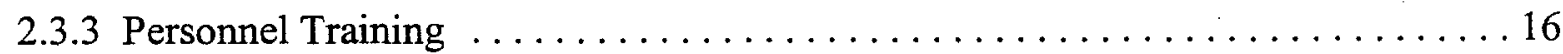

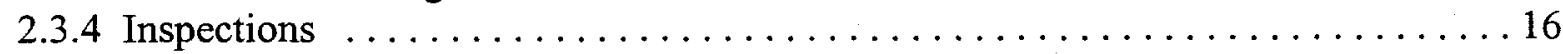

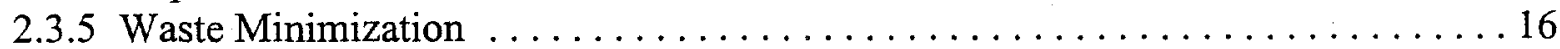

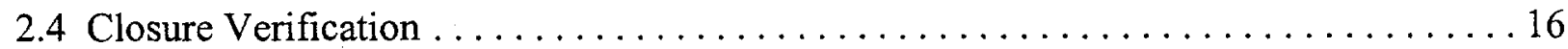

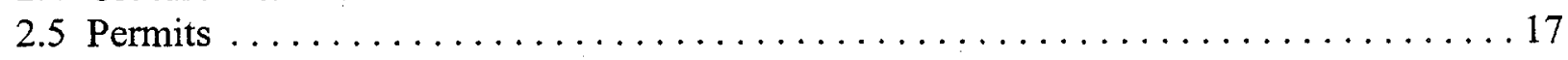

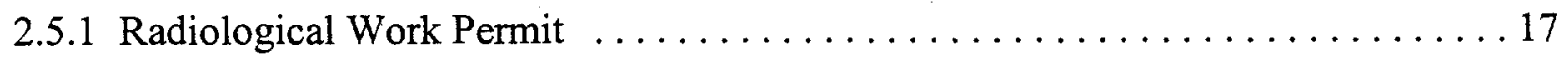

2.5.2 Excavation and Penetration Permit ............................. 17

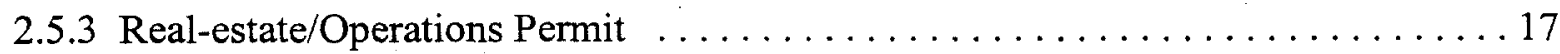

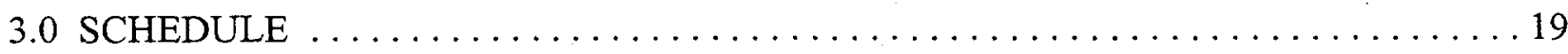

4.0 POST-CLOSURE MONITORING PLAN $\ldots \ldots \ldots \ldots \ldots \ldots \ldots \ldots \ldots \ldots \ldots \ldots \ldots \ldots \ldots$ 


\section{TABLE OF CONTENTS (continued)}

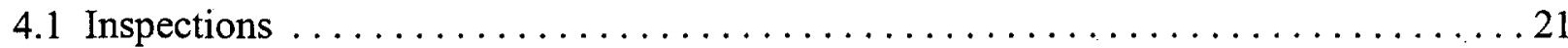

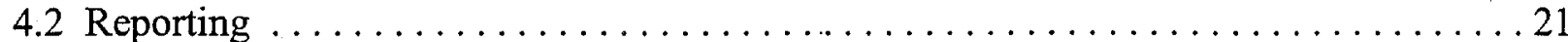

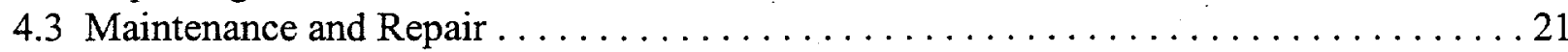

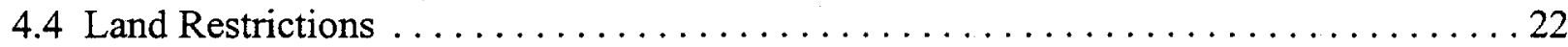

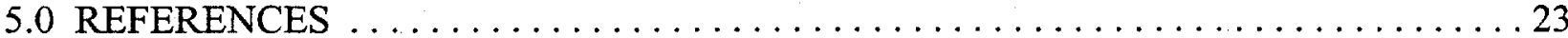

\section{FIGURES}

FIGURE 1 - CAU 407 Location Map $\ldots \ldots \ldots \ldots \ldots \ldots \ldots \ldots \ldots \ldots \ldots \ldots \ldots \ldots \ldots \ldots \ldots \ldots$

FIGURE 2 - CAU 407 Vicinity Map $\ldots \ldots \ldots \ldots \ldots \ldots \ldots \ldots \ldots \ldots \ldots \ldots \ldots \ldots \ldots \ldots$

FIGURE 3 - Locations of Surface Soils Identified as Over Three Times Bacground for Low Energy Gamma at the CAU 407 RCRSA $\ldots \ldots \ldots \ldots \ldots \ldots \ldots$

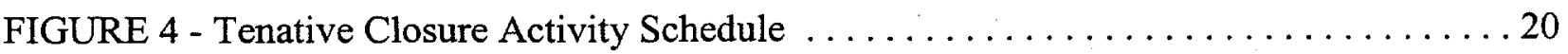

\section{TABLES}

TABLE 1 - Management of Various Waste Types to be Produced at RCRSA Closure 14

\section{APPENDICES}

APPENDIX A-1 Engineering Drawings Sampling, Inspection, Testing, and Acceptance Plan

APPENDIX A-2 Project Organization

APPENDIX B Flood Study

APPENDIX C NDEP Closure Plan Comment Response

DISTRIBUTION LIST 


\section{ACRONYMS AND ABBREVIATIONS}

\begin{tabular}{|c|c|c|}
\hline $\mathrm{BN}$ & & Bechtel Nevada \\
\hline CADD & & Corrective Action Decision Document \\
\hline CAP & & Corrective Action Plan \\
\hline CAU & & Corrective Action Unit \\
\hline $\mathrm{COCs}$ & & Constituent(s) of Concern \\
\hline $\mathrm{CR}$ & & Closure Report \\
\hline $\mathrm{DOE} / \mathrm{NV}$ & . & U.S. Department of Energy, Nevada Operations Office \\
\hline FFACO & & Federal Facility Agreement and Consent Order \\
\hline FIDLER & & Field Instrument for the Detection of Low Energy Radiation \\
\hline FMP & & Field Management Plan \\
\hline $\mathrm{ft}$ & & foot (feet) \\
\hline gal & & gallon \\
\hline $\mathrm{g} / \mathrm{cm}^{3}$ & & grams per cubic centimeter \\
\hline $\mathrm{km}$ & & kilometer(s) \\
\hline $\mathrm{km}^{2}$ & & square kilometer(s) \\
\hline $\mathrm{L}$ & & liter \\
\hline $\mathrm{m}$ & . & meter \\
\hline $\mathrm{mi}$ & & $\operatorname{mile}(s)$ \\
\hline NDEP & & Nevada Division of Environmental Protection \\
\hline NTS & & Nevada Test Site \\
\hline PPE & & Personal Protective equipment \\
\hline SITA & & Sampling, Inspection, Testing, and Acceptance Plan \\
\hline SSHASP & & Site-Specific Health and Safety Plan \\
\hline RCRSA & & Roller Coaster RADSAFE Area \\
\hline REOP & & Real-Estate/Operations Permit \\
\hline RWP & & Radiological Work Permit \\
\hline TTR & & Tonopah Test Range \\
\hline
\end{tabular}




\section{EXECUTIVE SUMMARY}

This Corrective Action Plan (CAP) has been prepared for the Roller Coaster RADSAFE Area Corrective Action Unit 407 in accordance with the Federal Facility and Consent Order (Nevada Division of Environmental Protection [NDEP] et al., 1996). This CAP provides the methodology for implementing the approved Corrective Action Alternative as listed in the Corrective Action Decision Document (U.S. Department of Energy, Nevada Operations Office, 1999).

The RCRSA was used during May and June of 1963 to decontaminate vehicles, equipment, and personnel from the Clean Slate tests. The Constituents of Concern (COCs) identified during the site characterization include plutonium, uranium, and americium. No other COCs were identified

The following closure actions will be implemented under this plan:

- Remove and dispose of surface soils which are over three times background for the area. Soils identified for removal will be disposed of at an approved disposal facility. Excavated areas will be backfilled with clean borrow soil from a nearby location.

- An engineered cover will be constructed over the waste disposal pit area where subsurface COCs will remain.

- Upon completion of the closure and approval of the Closure Report by NDEP, administrative controls, use restrictions, and site postings will be used to prevent intrusive activities at the site. Barbed wire fencing will be installed along the perimeter of this unit.

Post closure monitoring will consist of site inspections to determine the condition of the engineered cover. Any identified maintenance and repair requirements will be remedied within 90 working days of discovery and documented in writing at the time of repair. Results of all inspections/repairs for a given year will be addressed in a single report submitted annually to the NDEP. 


\subsection{INTRODUCTION}

This Corrective Action Plan (CAP) has been prepared for the Roller Coaster RADSAFE Area (RCRSA) Corrective Action Unit (CAU) 407 in accordance with the Federal Facility and Consent Order (FFACO) (Nevada Division of Environmental Protection [NDEP] et al., 1996). This CAP provides the methodology for implementing the approved Corrective Action Alternative as listed in the Corrective Action Decision Document (CADD) (U.S. Department of Energy, Nevada Operations Office [DOE/NV], 1999).

CAU 407 is located at the Tonopah Test Range (TTR), Nevada. The TTR is approximately 225 kilometers $(\mathrm{km})$ (140 miles [mi]) northwest of Las Vegas, Nevada (Figure 1). The RCRSA is located on the northeast corner of the intersection of Main Road and Browne's Lake Road, which is approximately $8 \mathrm{~km}(5 \mathrm{mi})$ south of Area 3 (Figure 1). The RCRSA was used during May and June of 1963 to decontaminate vehicles, equipment, and personnel from the Clean Slate tests.

Investigation of RCRSA was conducted from June through November of 1998. Gamma spectrometry, isotopic plutonium, and isotopic uranium analytical results above the preliminary action levels were reported for both surface and subsurface soils at the site (DOE/NV, 1999). The Constituents of Concern (COCs) include plutonium, uranium, and americium. No other COCs were identified.

\subsection{PURPOSE}

The purpose of this CAP is to provide the methodology for closing CAU 407, RCRSA as proposed in the CADD (DOE/NV, 1999).

\subsection{SCOPE}

Detailed information of the site history and results of the investigation activities can be found in the Corrective Action Investigation Plan (DOE/NV, 1998). The following closure actions will be implemented under this plan:

- $\quad$ Remove and dispose of surface soils which are over three times background for the area. Soils identified for removal will be disposed at an approved disposal facility. Excavated areas will be backfilled with clean borrow soil located near the site.

- An engineered cover will be constructed over the waste disposal pit area where subsurface COCs will remain (Figure 2). 


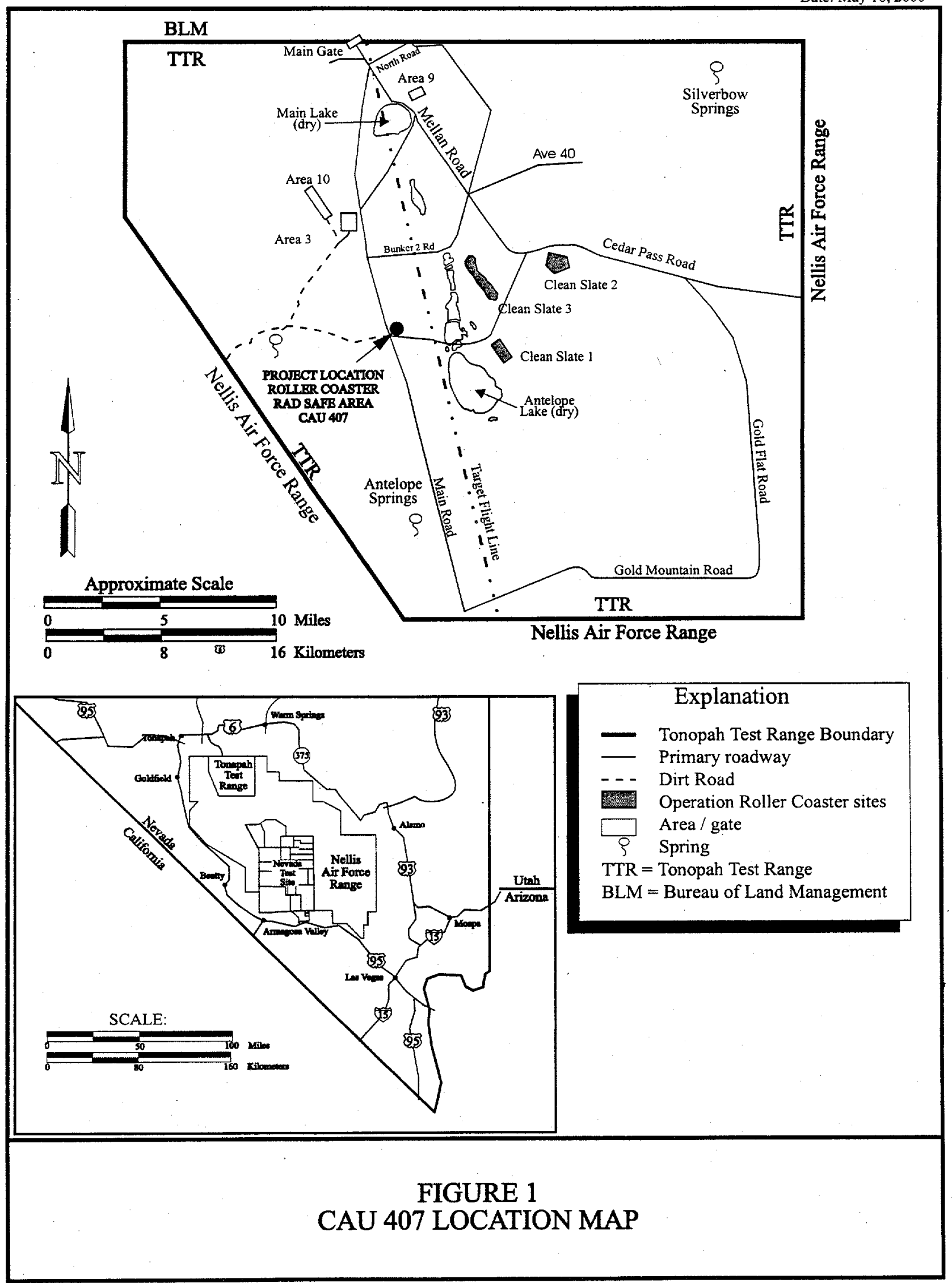




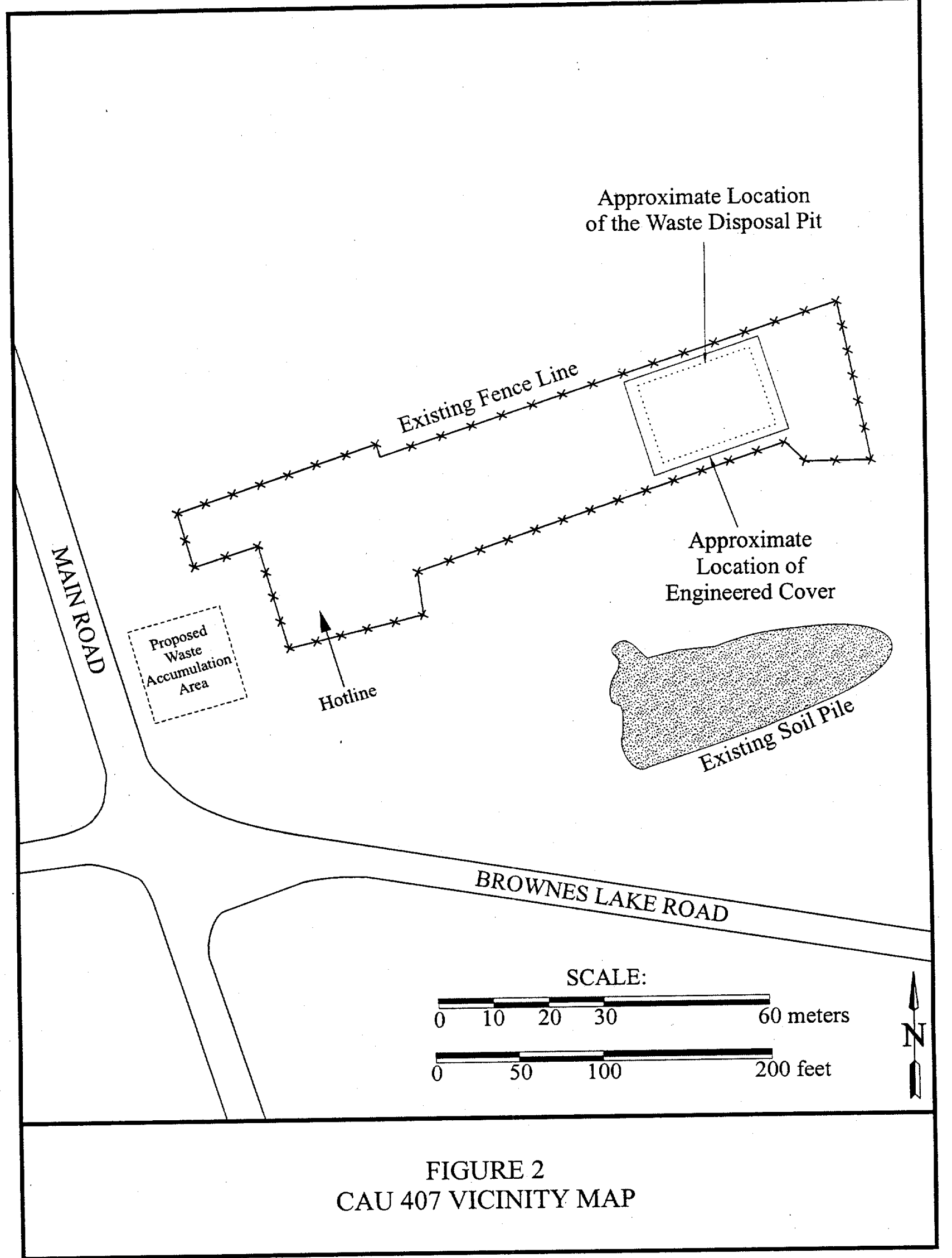


- Upon completion of the engineered cover and approval of the CAP and Closure Report (CR) by NDEP, administrative controls, use restrictions, and site postings will be used to prevent intrusive activities at the site. Barbed wire fencing will be installed along the perimeter of this unit.

\subsection{CORRECTIVE ACTION PLAN CONTENTS}

This CAP is divided into the following sections in accordance with the approved FFACO Corrective Action Plan outline:

Section 1.0 - Introduction

Section 2.0 - Detailed Statement of Work

Section 3.0 - Schedule

Section 4.0 - Post-Closure Monitoring Plan

Section 5.0 - References

The appendices of this document have been modified from the approved FFACO outlined. The following FFACO outline appendices have not been included or revised as indicated below:

- $\quad$ APPENDIX A-1 Engineering Specifications and Drawings This appendix is identified as Appendix A-1 Engineering Drawings and Sampling, Inspection, Testing, and Acceptance Plan.

- APPENDIX A-2 Sampling and Analysis Plan This appendix is not included because no physical samples will be collected for analysis. Clean-up verification will be accomplished using field screening instrumentation which is discussed in Section 2.4.

- APPENDIX A-3 Project Organization

This appendix is identified as Appendix A-2.

The appendices included in this document are provided as follows:

- APPENDIX A-1 Engineering Drawings and Sampling, Inspection, Testing, and Acceptance Plan

- APPENDIX A-2 Project Organization

- $\quad$ APPENDIX B Flood Study 
- APPENDIX C NDEP Closure Plan Comment Response

This plan was developed using information and guidance provided from the following documents:

Bechtel Nevada, 1999, Radioactive Waste Tracking, Handling, and Management at the NTS, OP-2151.304, Las Vegas, NV.

Bechtel Nevada, 1998, General Radiological Control Technician Field Instructions L-A14.107.H, Revision 1, Las Vegas, NV.

Fayer, M. J. and T. L. Jones, 1990, UNSAT-H Version 2.0: Unsaturated Soil Water and Heat Elow Model, Pacific Northwest Laboratory, Richland, WA. PNL-6779 UC-702.

Levitt, D. G., Sully, M. J., Dozer, B. L., and Lohrstorfer, C. F., 1999. Determining the Performance of an Arid Zone Radioactive Waste Site Through Site Characterization, Modeling and Monitoring, Proceedings of Waste Management ' 99 Conference, Tucson, Arizona.

Nevada Division of Environmental Protection, U.S. Department of Energy, and U.S. Department of Defense, 1996, Federal Facility Agreement and Consent Order (FFACO) of 1996.

U.S. Department of Energy, Nevada Operations Office, 1998. Corrective Action Investigation. Plan for the Roller Coaster RADSAFE Area, Corrective Action Unit 407: Nevada Test Site, Nevada Rev.0, DOE/NV--503. Las Vegas, NV.

U.S. Department of Energy, Nevada Operations Office, 1999. Corrective Action Decision Document for Corrective Action Unit 407: Nevada Test Site, Nevada Rev.0, DOE/NV--567. Las Vegas, NV.

U.S. Environmental Protection Agency, 1999, Title 29 Code of Federal Regulations 1910.120, Hazardous Waste Operations and Emergency Response, Washington, D.C. 
THIS PAGE INTENTIONALLY LEFT BLANK 


\subsection{DETAILED STATEMENT OF WORK}

\subsection{APPROVED ALTERNATIVE IMPLEMENTATION}

Based on the site characterization results (DOE/NV, 1999), the CADD recommends removal of the impacted surface soils and construction of an engineered cover over the portion of the site identified as the waste disposal pit. A detailed discussion of the closure strategy follows.

\subsubsection{Preplanning and Site Preparation}

The closure of RCRSA will include preplanning and site preparation before closure activities begin:

- $\quad$ Preparation of planning documents such as the Site-Specific Health and Safety Plan (SSHASP), and the Field Management Plan (FMP).

- Site preparation including utility clearance, work permits, and the verification of the surface hot spots.

- Identification and approval of a water source for dust suppression and other construction activities.

- Scheduling and coordination of work with Construction and Waste Management.

\subsubsection{Site-Specific Health and Safety Plan/Hazard Analysis}

A SSHASP and Hazard Assessment will be prepared. A task kick-off meeting will be held to discuss the scope of work and prepare the preliminary hazard analysis. A copy of the SSHASP will be kept on-file in the Bechtel Nevada (BN) Environmental Restoration and the BN Environmental, Safety, and Health Division Offices in Mercury, Nevada. The original document will be kept by the site supervisor at the work site. The SSHASP will be available on-site for review and signature by all workers prior to the beginning work at the site. The SSHASP will provide a detailed, job-specific plan covering protection against accidents or exposure of workers to contamination.

\subsubsection{Field Management Plan}

A FMP will be prepared for the closure activities. The plan will outline how the work will be accomplished and provide a detailed schedule for the project. In addition, it will identify the responsible parties for each aspect of the project and determine how decisions will be made. A 
copy of the FMP will be placed on file at the BN Environmental Restoration offices in Mercury, Nevada, and a copy will also be available at the project field site.

\subsubsection{National Environmental Policy Act Documentation}

A National Environmental Policy Act Checklist will be completed. Information from a biologic survey will be used to report on the condition of existing trees, shrubs, grassed area, and wildlife immediately adjacent to the area which may be affected by construction activities, equipment and material storage areas, and access routes.

\subsubsection{Closure Field Activities}

\subsubsection{Removal of Surface Impacted Soils}

Based on the surface radiation surveys for gross radiological activity, 16 surface locations were identified with activity readings which exceeded three times background as determined by the Field Instrument for the Detection of Low Energy Radiation (FIDLER) for the area (DOE/NV, 1999) (Figure 3). These soils will be removed. Excavated soil will be managed as low level radioactive waste. Impacted soil will be placed into either 55-gallon (gal) drums or B-25 containers following BN Procedure OP-2151.304, Radioactive Waste Tracking, Handling, and Management at the NTS, (BN, 1999) and stored temporarily in a waste management area (Figure 2) to await disposal following Section 2.3 of this CAP.

\subsection{Excavation}

The surface impacted soils will be excavated to a depth of 0.15 meters $(\mathrm{m})[0.5$ feet $(\mathrm{ft})]$ over an area of approximately 0.18 square meters ( 2 square feet). Verification screening will be performed after this soil has been removed. Screening will be conducted following Section 2.4 of this CAP. If field screening shows that surface readings remain greater than three times background, more soil will be excavated until the hot spot has been removed to a point were surface readings are below three times background.

\subsection{Site Restoration}

Once the hot spots have been removed as previously described, the excavated areas will be refilled with clean fill material to return the site to its original grade. Disturbances in the cleanclosed areas, will be revegetated using direct seeding of plants native to the area. Straw will be applied as a mulch after broadcast seeding. 

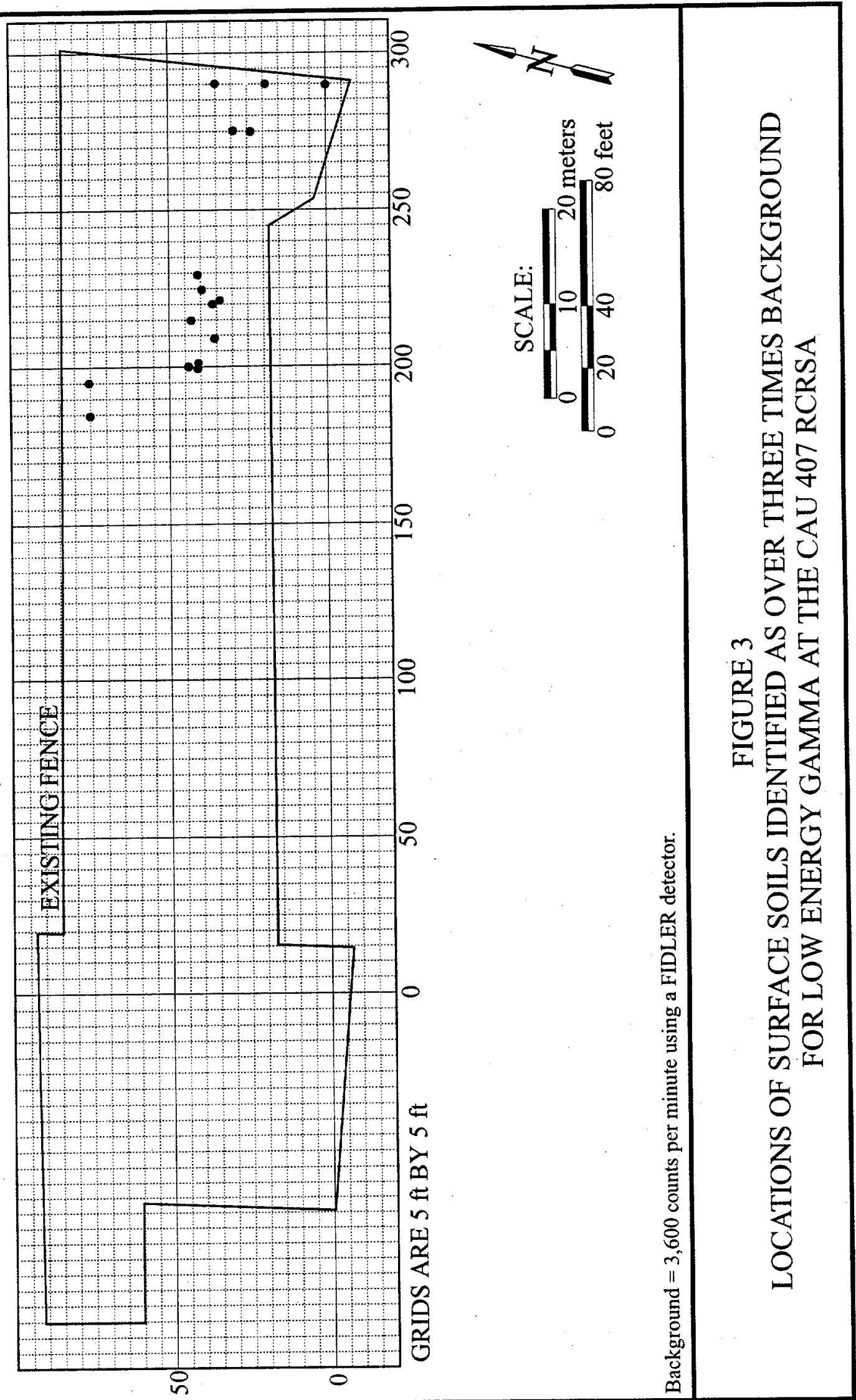


\subsubsection{Engineered Cover Construction}

The engineered cover design is a $0.6 \mathrm{~m}(2 \mathrm{ft})$ thick mono-layer of clean fill which will cover the historic waste pit (Figure 2). The main purpose of this layer is to provide an additional level of protection to the hypothetical future land user from subsurface radionuclides which will remain. Although the dose assessment presented in the CAU 407 CADD (DOE/NV, 1999) indicates that surface hot spots do not require removal if a cover is constructed, the radioactive soils will be removed, as discussed in section 2.1.2.1, prior to building the cover.

The transport of COCs from the site is not considered a viable pathway according to the Nevada Administrative Code 445A.227 (2) (a-k) criteria as presented in the CAU 407 CADD (DOE/NV, 1999). Therefore, this cover design is not meant to inhibit natural infiltration. The cover, will however, be revegetated with local native plants to help restore it to natural conditions. Once established, plants will aid in recycling infiltrated precipitation through transpiration although this is not their intended purpose. Appendix A provides the detailed engineering plan for the vegetated cover design.

\subsection{Design Criteria}

Although Resource Conservation and Recovery Act landfill closure regulations are not applicable for CAU 407, the cover design will be protective of the underlying material and environment. The design criteria are based on: the precipitation run-on and runoff, consolidation, and maintenance and repair.

\subsection{Run-on/Run-off}

Effects from run-on can be mitigated by grading the site to facilitate drainage. Based on a flood analysis to evaluate the flood hazard from the 25 -year 6-hour storm, the installation of diversion structures such as berms and/or channels to direct run-on away from the cover is not necessary. Effects from precipitation runoff will be mitigated with slope, and compaction (Appendix A).

Based on the site conditions discussed above, the necessary design criteria for minimizing precipitation run-on and runoff is to maintain a minimum slope of 2.0 percent on the cover surface. 


\subsection{Consolidation}

The waste pit at the RCRSA has been filled in since 1963 (DOE/NV, 1999). No evidence of settlement or consolidation has appeared at the surface to date. The average dry bulk density of cores extracted from the backfilled areas at the RCRSA is 1.61 grams per cubic centimeter $\left(\mathrm{g} / \mathrm{cm}^{3}\right)$. Values of dry bulk density typically range from 1.1 to $1.6 \mathrm{~g} / \mathrm{cm}^{3}$ (Jury et al., 1991). Given that the dry bulk density is on the high end of the range of bulk density for soils there is no reason to believe that further consolidation will occur.

The proposed cover will not be built to a compaction specification. The thickness of the

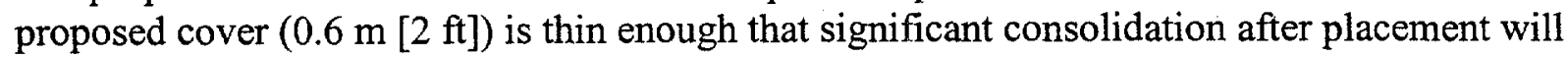
not be an issue.

\subsection{Maintenance and Repair}

Maintenance and repair were considered in the design since a cover should be designed to minimize maintenance/repair activities. Erosion and intrusive activities can impact the cover performance and influence the need for maintenance or repairs. Erosion is controlled by the presence of established vegetation, the slope, and gradation of the cover material. Intrusive activities from animals will be discouraged by the installation of fencing. Intrusion into the cover from human activities will be discouraged by the installation of a fence and signs. Therefore, the design criteria will require the following:

- The perimeter of the cover area will be fenced to minimize damage to the cover by humans and large animals.

- The perimeter of the cover area will have signs posted indicating the site conditions and prohibited activities.

- Periodic inspection of the cover will be conducted and repair/maintenance performed as required. The details of the cover inspection plan can be found in Section 4.0.

For details regarding the design criteria for the covers, see the Sampling, Inspection, Testing, and Acceptance (SITA) Plan (Appendix A).

\subsubsection{Establishing Vegetation}

The objective of revegetation is to provide for the long-term stabilization of the RCRSA cover and other areas disturbed during the construction of the cover. Vegetation on the cover will aid 
in reducing surface erosion although the primary purpose is to restore the site back to the natural surrounding conditions.

Vegetation will be established on the cover using direct seeding of local native vegetation. Prior to seeding, the cover surface will be ripped, plowed, and/or disced to a depth of approximately $0.4 \mathrm{~m}(1.3 \mathrm{ft})$. Straw will be applied to the area as a mulch after broadcast-seeding. A seed mixture of native plant species will be applied at a rate of 16.8 kilograms per hectare (15 pounds per acre) of pure live seed. A seed mixture using seed from native, shallow-rooted plant species will be applied between early October and late November. The seed planting time allows for dormancy breaking requirements to be met, and that the seed would be in the ground prior to the winter precipitation. Species in the seed mixture will include a combination of the following:

- $\quad$ Budsagebrush (Artemisia spinescens)

- Fourwing Saltbush (Atriplex canescens)

- Shadscale (Atriplex confertifolia)

- Winterfat (Krascheninnikovia lanata)

- Fluff Grass (Erioneuron pulchellum)

- Desert Globemallow (Sphaeralcea ambigua)

- Indian Ricegrass (Achnatherum hymenoides)

The objective for revegetation on the cover will be to establish vegetation similar to native undisturbed areas as quickly as possible. The goal is to establish a population of plant species equal to 25-50 percent of the native undisturbed areas.

Disturbances, other than the cover, e.g. the clean-closed areas, will be revegetated the same as the cover.

\subsubsection{DECONTAMINATION OF EQUIPMENT}

All equipment and materials used on-site will be surveyed for radiological constituents using hand-held Electras and swipe samples prior to release from the site. The decontamination rinsate that is collected will be placed in a 208-liter (L) (55-gallon [gal]) drum. Any equipment that becomes contaminated during the excavation or engineered cover grading process will be decontaminated on-site. For larger pieces of equipment that cannot be decontaminated over a 
208-L (55-gal) drum, a decontamination pad will be established by lining a bermed area large enough to hold a piece of heavy equipment. The equipment will be driven onto the pad and steam cleaned. Hand-held equipment will be cleaned with a solution of Alconox ${ }^{\mathrm{TM}}$ and water, and rinsed with clean water. Rinsate will be held in the bermed area and allowed to evaporate unless it is in excess of what the bermed area can hold. Excess rinsate will be pumped into drums. Any remaining rinsate at the time of final site housekeeping will be placed in containers and disposed of following Section 2.3 of this Closure Plan. The plastic liner will be placed in containers as compactable waste and disposed of in accordance with Section 2.3.

\subsection{CONSTRUCTION QUALITY ASSURANCE / QUALITY CONTROL}

A SITA Plan has been prepared to identify responsibilities, acceptance and approval, and documentation and records so that the result of the construction activities are according to the design. The SITA Plan and engineering drawings can be found in Appendix A.

\subsection{WASTE MANAGEMENT}

Activities will generate sanitary waste and low-level radioactive waste. No hazardous wastes are anticipated to be generated since site investigation activities indicate that the only COCs are radioactive isotopes of plutonium, uranium, and americium.

Sanitary waste will include construction debris, uncontaminated personal protective equipment (PPE), and trash generated by personnel on the site. These wastes will be transported to an approved sanitary landfill at the TT R or Nevada Test Site. These wastes may be containerized in drums if the size/quantity of materials permit. Drums used at the site for waste storage/disposal will be labeled as sanitary waste. Site personnel will adhere to the principles of the BN Waste Minimization and Pollution Prevention Program. Table 1 outlines the management of various waste types that could be generated by this closure activity.

\subsubsection{CONTAINER MANAGEMENT}

All containers will be handled in accordance with BN Organization Proceedure OP-2151.304 which covers the use and management of containers. All containers must be in good condition. If the container begins to leak, the contents must be transferred to a container that is in good condition. The containers must always be closed while stored unless waste is being added or removed. They must be handled in such a manner that will not jeopardize the integrity of the container. 
TABLE 1 - MANAGEMENT OF VARIOUS WASTE TYPES TO BE PRODUCED AT RCRSA CLOSURE

\begin{tabular}{|c|c|c|}
\hline MEDIA & WASTE TYPE & DECISION \\
\hline \multirow[t]{2}{*}{$\begin{array}{l}\text { Impacted Soil } \\
\text { and Surface } \\
\text { Debris }\end{array}$} & Low-Level Radioactive Waste & $\begin{array}{l}\text { Low-level waste will be managed in accordance with the BN Procedure OP-2151.304, } \\
\text { Radioactive Waste Tracking, Handling, and Management at the NTS (BN, 1999). Waste will be } \\
\text { placed into containers, labeled, and placed in the designated waste management area. If } \\
\text { necessary, absorbent will be added. Appropriate paperwork (Package Inventory, Waste Traveler, } \\
\text { Packaging Certification, Radioactive Material Shipping Exception Record or Radioactive } \\
\text { Material Shipping Record, Waste Shipment Checklist, and Certification Statement) will be } \\
\text { completed prior to shipment for disposal. }\end{array}$ \\
\hline & $\begin{array}{l}\text { Levels Less Than Regulated } \\
\text { Limits }\end{array}$ & The soil will be returned to excavation and used as backfill material. \\
\hline \multirow[t]{2}{*}{$\begin{array}{l}\text { Decontamination } \\
\text { Rinsate and } \\
\text { Liner }\end{array}$} & Low-Level Radioactive Waste & $\begin{array}{l}\text { Waste will be managed in accordance with the BN Procedure OP-2151.304, Radioactive Waste } \\
\text { Tracking. Handling, and Management at the NTS (BN, 1999). Waste will be solidified using } \\
\text { Aqua-Set }{ }^{2} \text { or an equivalent approved solidification agent, placed into containers, labeled, and } \\
\text { placed in the designated waste management area. Appropriate paperwork (Package Inventory, } \\
\text { Waste Traveler, Packaging Certification, Radioactive Material Shipping Exception Record or } \\
\text { Radioactive Material Shipping Record, Waste Shipment Checklist, and Certification Statement) } \\
\text { will be completed prior to shipment for disposal. }\end{array}$ \\
\hline & $\begin{array}{l}\text { Levels Less Than Regulated } \\
\text { Limits }\end{array}$ & $\begin{array}{l}\text { Waste will be allowed to evaporate or solidified, if necessary, and subsequently transported to the } \\
\text { Area 9, U10C Landfill for disposal. }\end{array}$ \\
\hline \multirow[t]{2}{*}{$\begin{array}{l}\text { PPE and } \\
\text { Sampling } \\
\text { Equipment }\end{array}$} & $\begin{array}{l}\text { Low-Level Radioactive Waste } \\
\text { (Based on Field-Screening } \\
\text { Background Levels) }\end{array}$ & $\begin{array}{l}\text { Waste will be managed in accordance with the BN STET OP-2151.304, Radioactive Waste } \\
\text { Tracking. Handling, and Management at the NTS (BN, 1999). PPE generated in association with } \\
\text { a hotline will also be managed in accordance with BN Local Implementation Document L- } \\
\text { A14.107.H, General Radiological Control Technician Field Instructions (BN, 1998). PPE will be } \\
\text { placed in the containers of soil to occupy any void space in the container. }\end{array}$ \\
\hline & $\begin{array}{l}\text { Levels Less Than Field-Screening } \\
\text { Background_Levels. }\end{array}$ & $\begin{array}{l}\text { Waste will be managed as sanitary waste and transported to the Area 9, U10C Landfill for } \\
\text { disposal or alternately to the TTR sanitary landfill }\end{array}$ \\
\hline
\end{tabular}


Some combination of B-25 boxes or 55-gal drums will be used during this project. Containers will not be filled above their specified weight capacity. Compactable waste will then be placed in 208-L (55-gal) drums. After a container has been filled, the container will be locked. If a container is not completely filled to capacity at the end of a work day, it will be locked and tamper-resistant tape will be placed over the container's hinge. Additional precautions include not filling 208-L (55-gal) drums more than 7/8 full and not mixing waste types.

The majority of waste produced is anticipated to be soil and debris. Secondary containment will not be required. If, however, free liquids are placed in containers, such as decontamination water, the containers will be placed on spill containment pallets.

Appropriate labels and relevant information will be marked on each container with an indelible marker and must be legible and clearly visible for inspections. Pertinent data may be written on duct tape or a blank adhesive label that is applied to the side of the container. The following information will be included:

- Waste-Tracking Label.

- Type of waste in the container (i.e., it must be marked "Radioactive Waste").

- Location waste was derived from.

- Date accumulation begins/ends.

- If sampling is required "Awaiting Analysis" sticker after sampling has been completed.

\subsubsection{Site Control}

A fenced waste storage area will be established outside of the work area to store material that could potentially be low-level radioactive waste. This will consist primarily of the B-25 containers and/or 208-L (55-gal) drums. Figure 2 shows the planned location for the waste management area. This location may change as field conditions dictate.

The site is currently fenced. This fencing will be maintained during site remediation activities. A hotline will be set up (Figure 2) and only properly trained personnel wearing appropriate PPE will be allowed access to the exclusion zone. All equipment and materials will be surveyed for radiation prior to removal from the exclusion zone. 


\subsubsection{Personnel Training}

All personnel responsible for packing low-level or mixed radioactive waste will be required to read and understand BN Procedure OP-2151.304, Radioactive Waste Tracking, Handling, and Management at the NTS (BN, 1999).

Title 29 Code of Federal Regulations $\S 1910.120$ (U.S. Environmental Protection Adgency [EPA], 1999) details the occupational safety and health requirements that will be followed for personnel supporting excavation activities. All personnel will be required to read and understand the SSHASP prior to working at the site. A tailgate safety briefing will be conducted every morning and as needed as activities or circumstances change. In addition, all personnel will require 40-hour Occupational Safety and Health Administration and Radiation Worker II training.

\subsubsection{Inspections}

The waste containers will be visually inspected prior to demobilizing from the site and at the time of un loading at the Area 6 Decontamination Facility or designated waste facility. An inspection of the areas in which the containers are stored will be conducted at least weekly if the waste containers remain on the site for more than a week. The purpose is to identify leaking or deteriorating containers due to corrosion or other factors. Unusual circumstances must be reported immediately so that corrective measures can be taken. Completed inspection forms will be maintained in the project file.

\subsubsection{Waste Minimization}

For the duration of the project, site workers will adhere to the principles of the BN Waste Minimization and Pollution Prevention Program. Care will be taken to segregate waste from non-waste materials if at all possible and avoid cross contamination

\subsection{CLOSURE VERIFICATION}

Prior to the excavation of the "hot spots," background readings will be established for the field screening instrumentation. These instruments will be used to determine if the surface hot spots have been removed such that readings are no longer above three times the established background. 


\subsection{PERMITS}

Required permits for this project include a Radiological Work Permit (RWP), Excavation and Trenching Permit, and Real-Estate/Operations Permit (REOP).

\subsubsection{RWP}

An RWP has been prepared and approved to inform workers of the specific PPE necessary to protect them while performing their tasks. The workers will be required to read the permit and acknowledge their understanding of the requirements before entry into the exclusion zone. The RWP will be maintained by the radiological control personnel at the access station. All site workers will be required to be Radiation Worker II-certified while the RWP is in effect.

\subsubsection{Excavating and Penetration Permit}

An approved Excavating and Trenching Permit will be obtained prior to any excavation. The permit contains a justification for the trenching operation and a checklist of pertinent organizations which must inspect the site so that the trenching will not impact utilities or harm workers. A copy of this permit will be kept at the project site by the site supervisor.

\subsubsection{REOP}

A REOP will be obtained prior to beginning field closure activities. This permit will establish DOE/NV authorization and control to accomplish the following:

- Establish one organization as being responsible for safety.

- Identify hazards and controls associated with field operations pertinent to the site.

- Identify the hazardous material inventory, if any, located at the site for emergency response purposes.

- Ensure DOENV has reviewed and approved all work conducted in association with the site.

- Identify DOE/NV's responsibility to plan and schedule activities.

- Provide a mechanism to recover applicable infrastructure support costs. 
THIS PAGE LEFT INTENTIONALLY BLANK

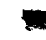




\subsection{SCHEDULE}

The CAU 407 RCRSA closure schedule is outlined in Appendix III of the FFACO. The FFACO schedule requires that this plan be submitted for NDEP approval by May 26,2000, and that the CR be submitted for NDEP approval by April 27, 2001.

The project schedule for the closure can be found in Figure 4. Flexibility has been placed in the project schedule to account for minor difficulties (weather, equipment breakdowns, etc.).

DOE/NV will keep the NDEP appraised of any condition that may impact the project schedule. In the event that the project schedule requires modification, the DOE $\mathrm{NV}$ will consult with NDEP personnel prior to making any changes. 


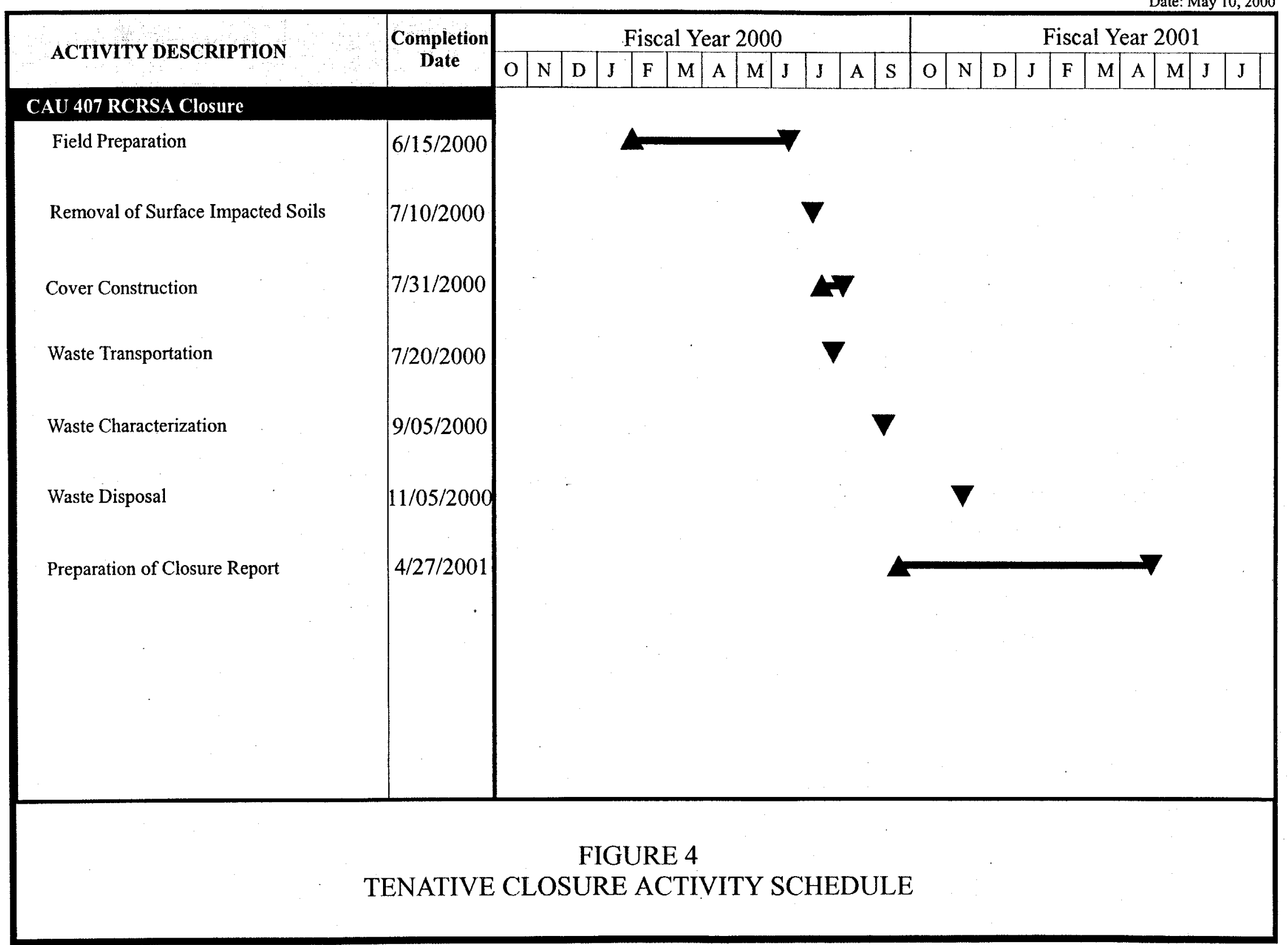




\subsection{POST-CLOSURE MONITORING PLAN}

Post-closure monitoring will consist of site inspections to determine the condition of the engineered cover.

\subsection{INSPECTIONS}

Inspections consist of visually inspecting the cover for signs of erosion, animal burrows, cracks, water ponding, vegetation, and inspecting the fencing and postings. Inspections will be performed twice during the first six months after construction of the cover has been completed. After completion of the quarterly inspections, the cover systems will be inspected and monitored semiannually (twice per year) for the next two years. The frequency after the second year will be determined by NDEP, based on the results of the previous inspections. Any identified maintenance and repair requirements will be remedied within 90 working days of discovery and documented in writing at the time of repair.

\subsection{REPORTING}

Results of all inspections in a given year will be addressed in a single annual report. The annual report will include the following information:

- Discussion of observations.

- Inspection checklist and maintenance record.

- Conclusions and recommendations.

A copy of each annual report will be submitted to the NDEP. A copy of the inspection checklist will be provided in the final CAP.

\subsection{MAINTENANCE AND REPAIR}

Following the a field inspection, cover maintenance/repair will be performed if necessary. Maintenance/repair activities will be included in the annual report submitted to the NDEP. 


\subsection{LAND RESTRICTIONS}

The future use of any land related to the RCRSA is restricted from any activity that may alter or modify the containment control as approved by the state and identified in the RCRSA CR unless appropriate concurrence is obtained in advance.

The CAU Land Use Restriction form will be completed. This form includes the CAU number and site description, post-closure monitoring requirements, and survey coordinates of the unit boundaries. The information on the completed form will be added to the DOE/NV Facility Information Management System and the Central Data Repository. The original CAU Land Use Restriction from is then filed within the CAU 407 project file. 


\subsection{REFERENCES}

BN, see Bechtel Nevada.

Bechtel Nevada, 1999. Radioactive Waste Tracking, Handling, and Management at the NTS, OP-2151.304, Las Vegas, NV.

Bechtel Nevada, 1998. General Radiological Control Technician Field Instructions L-A14.107.H, Revision 1, Las Vegas, NV.

DOE/NV, see U.S. Department of Energy, Nevada Operations Office

EPA, see U.S. Environmental Protection Agency

Fayer, M. J. and T. L. Jones, 1990. UNSAT-H Version 2.0: Unsaturated Soil Water and Heat Elow Model. Pacific Northwest Laboratory, Richland, WA. PNL-6779 UC-702.

Jury, W. A., W. R. Gardner, W. A., 1991. Soil Physics fifth edition. John Wiley \& Sons, Inc. New York.

Levitt, D. G., Sully, M. J., Dozer, B. L., and Lohrstorfer, C.F., 1999. Determining the Performance of an Arid Zone Radioactive Waste Site Through Site Characterization, Modeling and Monitoring. Proceedings of Waste Management ' 99 Conference, Tucson, AZ.

NDEP, see Nevada Division of Environmental Protection

Nevada Administrative Code, 1998. NAC 445A, Water Controls. Carson City, NV.

Nevada Division of Environmental Protection, U.S. Department of Energy, and U.S. Department of Defense. 1996. Federal Facility Agreement and Consent Order (FFACQ) of 1996.

U.S. Department of Energy, Nevada Operations Office, 1998. Corrective Action Investigation. Plan for the Roller Coaster RADSAFE Area, Corrective Action Unit 407: Nevada Test Site, Nevada Rev.0, DOE/NV--503. Las Vegas, NV.

U.S. Department of Energy, Nevada Operations Office, 1999. Corrective Action Decision Document for Corrective Action Unit 407: Nevada Test Site, Nevada Rev.0, DOE/NV--567. Las Vegas, NV. 


\subsection{REFERENCES (Continued)}

U.S. Environmental Protection Agency, 1999. Title 29 Code of Federal Regulations 1910.120, "Hazardous Waste Operations and Emergency Response," Washington, D.C. 


\section{APPENDIX A-1 \\ ENGINEERING DRAWINGS AND \\ SAMPLING, INSPECTION, TESTING, AND ACCEPTANCE PLAN}





\section{Bechtel Nevada}

Page 1 of 1

ENGINEERING TRANSMITTAL NO.: DDD2170D-00-414

M/S NLV085

DOCUMENT DRAWING DISTRIBUTION

DATE:

$05 / 09 / 00$

SUBJECT TTR CAU 407 REMEDIATION, ROLLER COASTER RADSAFE AREA

PROJECT NO: 00022.A54 ID NO.: C7CO13BB

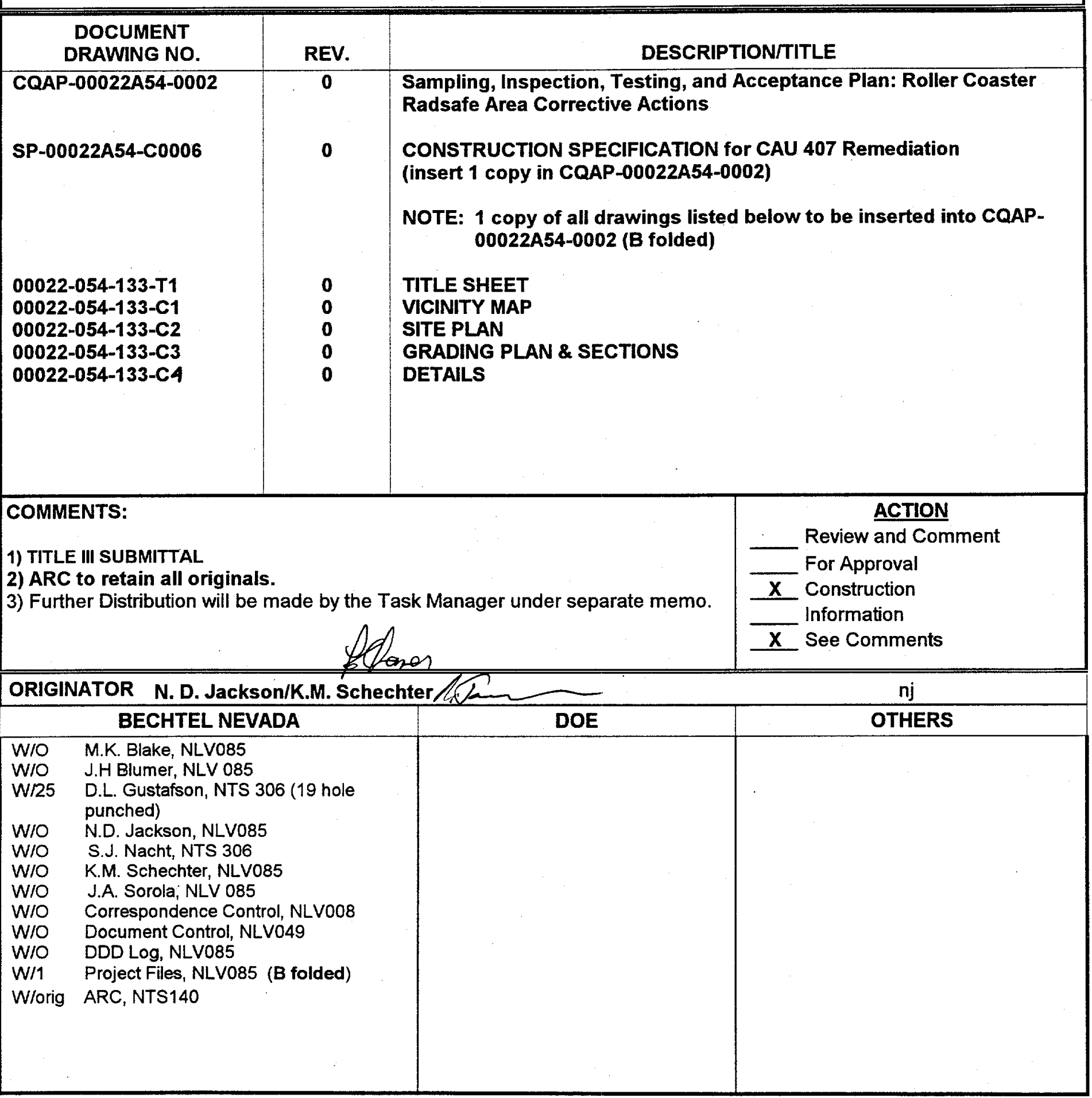




\section{Bechtel Nevada}

\section{CORRECTIVE ACTION UNIT 407 \\ TONOPAH TEST RANGE, NEVADA}

SAMPLING, INSPECTION, TESTING, AND ACCEPTANCE PLAN:

\section{ROLLER COASTER RADSAFE AREA CORRECTIVE ACTIONS}

Document No: CQAP-00022A54-0002, Rev 0

MAY 2000

U.S. Department of Energy

Nevada Operations Office

Prepared by Bechtel Nevada 
CORRECTIVE ACTION UNIT 407

TONOPAH TEST RANGE, NEVADA

SAMPLING, INSPECTION, TESTING, AND ACCEPTANCE PLAN:

ROLLER COASTER RADSAFE AREA

CORRECTIVE ACTIONS

\section{BECHTEL NEVADA}

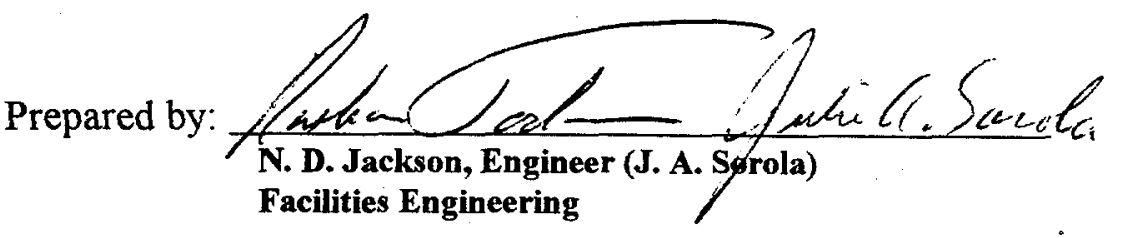

Date: $5 / 8 / 00$

Approved by:

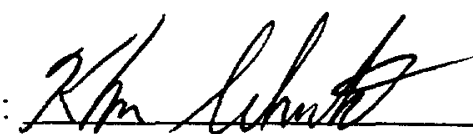

K.M.Schechter, Manager

Design Engineering

Approved by: Allulal Whottor

for S. J. Nacht, Project Engineer

Environmental Restoration

Date: $5 / 9 / 00$

Date: $5-9-00$

Approved by: Hluhal Nestors

for W. F. Johnson, Project Manager

Environmental Restoration

Date: $5-9-00$ 


\section{TABLE OF CONTENTS}

SECTION I - Plan Narrative

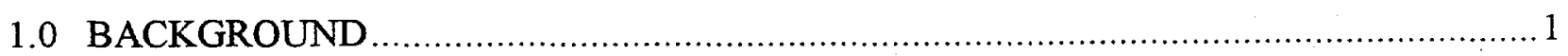

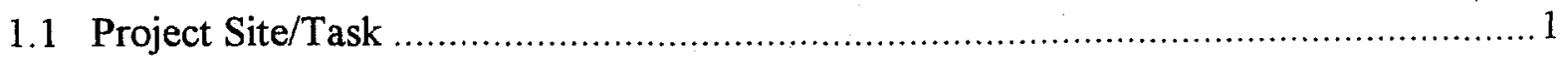

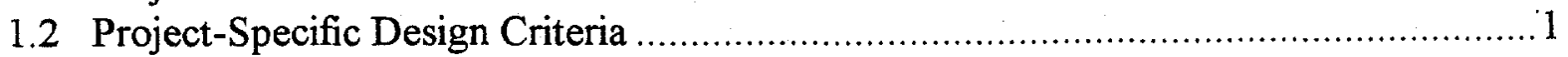

1.3 Sampling, Inspection, Testing, and Acceptance (SITA) Plan Outline ........................ 1

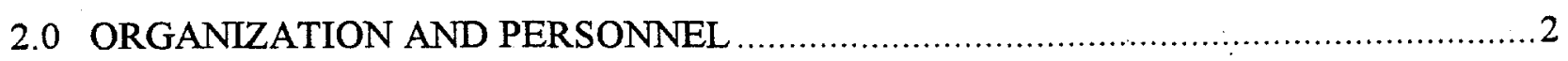

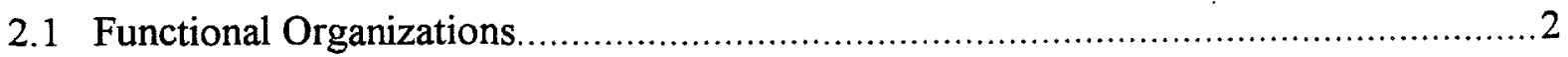

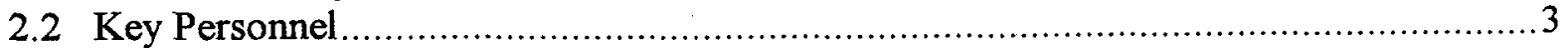

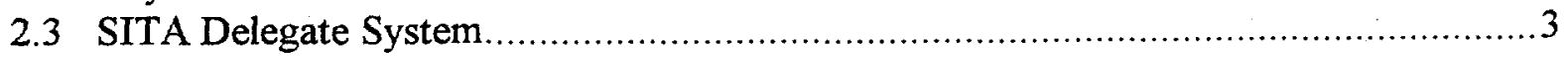

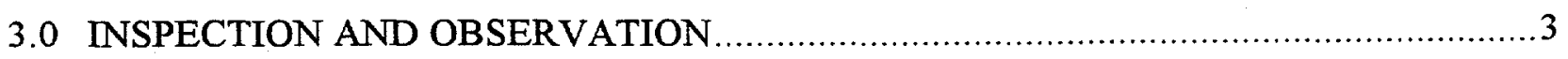

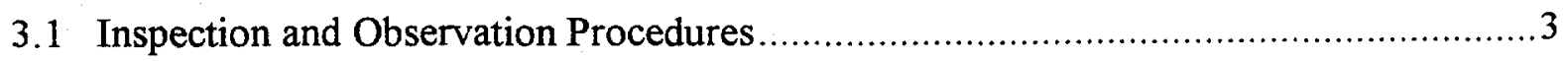

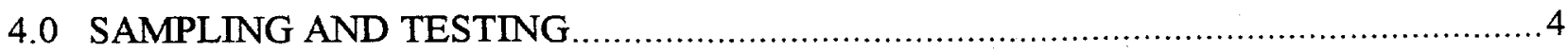

4.1 Sampling and Testing Procedures - Not Applicable ............................................... 4

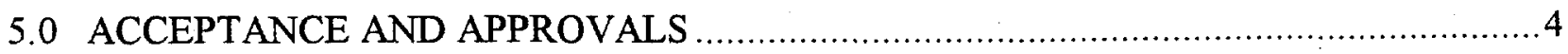

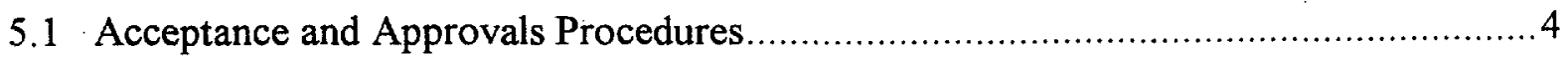

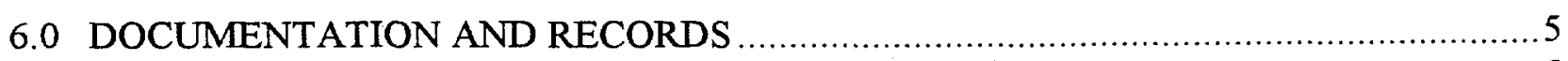

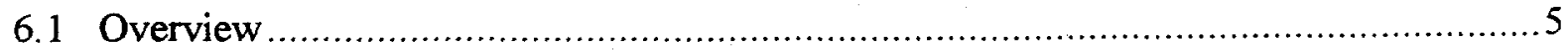

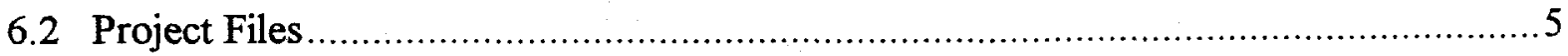

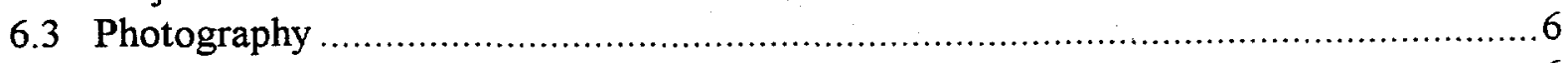

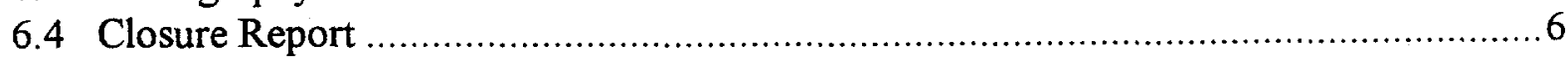

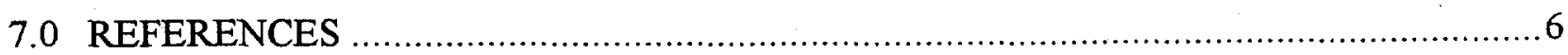

SECTION II - SITA Plan Tables and Guides

SECTION III - Engineering Drawings

SECTION IV - Construction Specifications 


\section{SECTION I}

\section{PLAN NARRATIVE}




\section{SECTION I \\ Plan Narrative}

\subsection{BACKGROUND}

\section{$1.1 \quad$ Project Site/Task}

The Corrective Action Unit (CAU) 407, Tonopah Test Range, Nevada has a singular Corrective Action Site (CAS) TA-23-001-TARC. Work associated with the remediation of this CAU and its associated $\mathrm{CAS}$ is as follows:

- Thirteen (13) surface locations determined to have elevated levels of radioactive constituents will be partially excavated and covered. (contaminated soils removed);

- The existing Waste Disposal Pit (covered) will be permanently closed, fenced and posted.

\subsection{Project-Specific Design Criteria}

The project-specific design criteria have been summarized in the Engineering Plan for $C A U 407$ TTR, Nevada. The four basic closure cap performance/technical objectives criteria are to:

- Function with minimum maintenance

- $\quad$ Promote drainage and minimize erosion or abrasion of the cover

\subsection{Sampling, Inspection, Testing, and Acceptance (SITA) Plan Outline}

This SITA Plan was developed in accordance with the Environmental Protection Agency (EPA) Technical Guidance Document, Quality Assurance and Quality Control for Waste Containment Facilities." Application of the guidelines are listed below and are addressed in detail later in this project document.
- Organization and Personnel
- Inspection and Observation
- Sampling and Testing
- Acceptance and Approvals
- Documentation and Records
- References 


\subsection{ORGANIZATION AND PERSONNEL}

\subsection{Functional Organizations}

The organizations actively involved in regulating, designing, and constructing functions during the CAU 407 TTR, Roller Coaster Radsafe Area remediation project are listed below:

$\begin{array}{lll}\text { U.S. Department of Energy (DOE) } & \text { Owner } \\ \text { State of Nevada (NDEP) } & \begin{array}{l}\text { Regulating agency (Nevada Division of } \\ \text { Environmental Protection) }\end{array} \\ & \text { Bechtel Nevada (BN) } & \begin{array}{l}\text { Environmental Restoration, Engineering, } \\ \text { Construction, and Support Services }\end{array} \\ & \text { Other (Subcontract[s]) } & \text { Material Testing Laboratory (MTL) services }\end{array}$

The relationships, roles, and responsibilities of the principal organizations are depicted in the Project Functional Organization Chart (Figure 2.1).

CAU 407 ROLLER COASTER RADSAFE AREA -- Project Functional Organization Chart



Figure 2.1 


\subsection{Key Personnel}

Key personnel for this project are listed below; however, personnel are subject to change and it is suggested that the BN/ER Project Manager be contacted for further information.

$\begin{array}{ll}\text { ER Project Manager } & \text { W. F. Johnson } \\ \text { Project Engineer } & \text { S. J. Nacht* } \\ \text { Task Manager } & \text { D. L. Gustafson* } \\ \text { Senior Engineer } & \text { J. A. Sorola* } \\ \text { Engineer } & \text { N. D. Jackson* } \\ \text { Senior Engineer Assistant } & \text { G. G. Hudak* } \\ \text { Geotechnical Engineer } & \text { E. A. Strassburger* } \\ \text { Technical Lead } & \text { T.M. Fitzmaurice* } \\ \text { ER Construction Manager } & \text { J.G. Nelson* } \\ \text { Field Coordinator } & \text { P.F. Brown } \\ \text { Construction Superintendent } & \text { J. S. Pennington* } \\ \text { Construction Engineer } & \text { J. A. Joines*. } \\ \text { Survey Supervisor } & \text { S. J. Ellison* } \\ \text { Materials Testing Supervisor } & \text { C. D. Herrington } \\ \text { * SITA Delegates (see below) } & \end{array}$

\subsection{SITA Delegate System}

To ensure optimum productivity during construction, the SITA delegate system was developed. The SITA delegate selection and assignments are delegated by the Project Manager. Using this method permits numerous construction tasks to be achieved with a minimum number of personnel required to be on site at any given time.

\subsection{INSPECTION AND OBSERVATION}

\subsection{Inspection and Observation Procedures}

The itemized SITA Plan Tables and Guides section contains specific guidance for inspection and acceptance operations for this project (see Section II). A completed copy of the SITA Plan Tables will become a part of the closure report at project completion.

Inspection and observation personnel (SITA delegates) will be responsible for Title III (construction) acceptance functions, and shall provide acceptance/rejection and inspection/ observation activities in conjunction with procedures shown in the SITA Plan Tables and Guides. Acceptance shall be in accordance with current design requirements specified in the technical documents (design drawings/specifications) contained herein (see Sections III and IV).

The SITA delegate's observations will be used to verify that the materials, equipment, and methods of construction meet all design criteria and plans, and are documented, as a minimum, in the project daily log book and daily report(s). 
The SITA Tables contain a column listing mandatory construction task HPs. These task HPs must be addressed and the task approved by the responsible SITA delegate(s) prior to continuing with the construction sequence.

\subsection{SAMPLING AND TESTING}

\subsection{Sampling and Testing Procedures - Not Applicable}

\subsection{ACCEPTANCE AND APPROVALS}

\subsection{Acceptance and Approvals Procedures}

The procedure(s) for acceptance and/or approvals for various construction tasks, as specified in the SITA Plan Tables, drawings, and specifications, have been addressed in Section 3.0 above.

5.1.1 The ultimate BN authorization authority is the authorized representative (AR) for the project. This assignment is filled by the Project Manager (with guidance by other key personnel).

5.1.2 The AR is supported by a team of technically qualified environmental personnel, as specified in Part 2.2, Key Personnel. This team of key personnel is identified as the SITA Delegates, and either individually or collectively, will perform acceptance and/or approvals, as the requirement arises. The titles Project Manager Delegate and SITA Delegate are synonymous.

5.1.3 As previously discussed, the construction tasks requiring acceptance and/or approvals include, but are not limited to, the following:

- Material test results

- Adherence to specifications

- Compliance with drawings

- Deviations to plans/procedures

- Survey field data

- Alterations for performance improvements

- SITA Plan Tables task HPs

5.1.4 Acceptance and/or approvals of construction tasks controlled by HPs, or proposed alteration of any task specified in the engineering technical documents contained within this SITA Plan, must have the concurrence of an Engineering SITA delegate. Refer to Part 2.2, Key Personnel list, for names of engineering delegates.

5.1.5 Acceptance and/or approvals of construction and non-construction tasks controlled by a "Check Point" (CP) only requires verification by a SITA Delegate, followed by notification to other delegates when convenient, with no work stoppage or other delays. 


\subsection{DOCUMENTATION AND RECORDS}

\subsection{Overview}

The document types which will be generated or referenced as part of this SITA Plan by the various organizations involved in this project include:

- Project Corrective Action Plan (CAP) and Closure Report (CR)

- Conference reports

- $\quad$ Project schedule(s)

- Materials field sampling/testing tables and guides (Section II)

- Design drawings and their revisions (Section III)

- Construction specifications and their revisions (Section IV)

- Design calculations and material test data (Section V)

- Project-specific daily log book (maintained by the Technical Lead)

- Project-specific Construction Work Plan*

- Project-specific inspection plan*

- Daily construction/site activity summary reports/memos (maintained by the Technical Lead)

- Inspection or observation document(s) (provided by SITA delegates)

- Material/test data sheets (sampling and testing)

- In-field survey data sheets

- Design interim change (Design Change Notice, Field Change Notice)

- Deficiency documents (correctable deficiency log/nonconformance reports)

- Final inspection/survey as-built drawings

* Supervisory personnel review/concurrence with this SITA Plan prior to start of construction/inspection activities will waive the requirement for separate documents. SITA delegates will also have reviewed and understand their responsibilities before performing any Title III construction tasks.

In addition, other miscellaneous documents, i.e., memos, sketches, audits, etc., will become a part of the project records file.

\subsection{Project Files}

The project files will be located at the job site and will include a controlled copy of each of the following:

- Approved SITA Plan

- Project drawings and specifications_- "as-builts"

- Inspection/observations

- $\quad$ Project-specific daily log

- Survey data

The project files will be maintained by the Field Coordinator and/or Technical Lead. After construction, the project files will be located in the BN/ER project files. Original as-built 
drawings will be retained at the Archives Records Center (ARC) in Mercury, NTS. Any copies required in the future can be provided by the $\mathrm{ARC}$ in hard copy or electronic form.

\subsection{Photography}

Preparing and maintaining a photographic log of all note-worthy construction activities, including sampling/testing activities, is the responsibility of the Technical Lead. Photographs will be clearly marked as to photographer identity, date, time, and brief description of each activity, and will be kept in a separate log as part of the central file.

\subsection{Closure Report}

A final construction/project CR will be prepared and will contain or reference the following:

- Copy of the signed-off (approved) SITA Plan Tables

- Summary documentation of design and construction activities

- Daily logs, intermediate reports, and other related documentation to support in-situ (as constructed) conditions

- Copies of as-built drawings and sketches

- Photographs of the completed project site (if requested/required by DOE/NDEP)

\subsection{REFERENCES}

American Society for Testing and Materials (ASTM), Annual Book of ASTM Standards. 1999.

B-A20/96.01, Bechtel Nevada Performance Assurance Management Plan. April 24, 1997.

Engineering Plan for Corrective Action Unit 407 TONOPAH TEST RANGE, Nevada. Revision 2. November 1999. BN.

Environmental Protection Agency Technical Guidance Document, Quality Assurance and Quality Control for Waste Containment Facilities. EPA/600/R-93/182. September 1993.

U.S. Department of Energy, Corrective Action Plan for CAU 407 RCRSA

U.S. Department of Energy Order 451.1A, National Environmental Policy Act Compliance Program, DOE 1997.

U.S. Department of Energy Order 430.1, Life-Cycle Asset Management. 1999.

U.S. Department of Energy Order 5700.6C; Quality Assurance. 1991. 


\section{SECTION II}

\section{SITA PLAN \\ TABLES AND GUIDE}




\section{SITA PLAN TABLES AND GUIDES INDEX}

\section{TABLES}

I Roller Coaster Radsafe Area -- Preclosure Tasks

II Roller Coaster Radsafe Area, Waste Disposal Pit -- Closure Tasks

\section{GUIDES - Not Applicable}




\section{SECTION II}

SITA Plan Table I

Site: Roller Coaster Radsafe Area -- Preclosure Tasks
REVISION : $\quad 0$

DATE: $\underline{05 / 09 / 00}$

General instructions for using the SITA Plan Tables and guides:

1. For sampling/testing activities specified herein, use the appropriate SITA Guide Sheet.

2. All sampling/testing locations will be random and shown on the appropriate SITA Guide Sheet.

3. Acceptance and/or approval will be made by one (or more) of the SITA delegates (see Section I, Part 2.2 and Part 5.0 for guidance)

4. All HPs must be initialed by the responsible SITA delegate prior to continuance to the next phase of construction.

\begin{tabular}{|c|c|c|c|c|c|c|c|c|}
\hline \multirow[b]{2}{*}{$\begin{array}{l}\text { Construction } \\
\text { Phase }\end{array}$} & \multirow[b]{2}{*}{ SITA Task } & \multirow[b]{2}{*}{ SITA Method(s) } & \multirow{2}{*}{$\begin{array}{c}\begin{array}{c}\text { Sample/Test } \\
\text { Quantity/Frequency }\end{array} \\
\text { Other Instructions }\end{array}$} & \multicolumn{2}{|c|}{$\begin{array}{l}\text { Sample/Location/ } \\
\text { Requirement }\end{array}$} & \multicolumn{2}{|c|}{$\begin{array}{c}\text { Task } \\
\text { Acceptance } \\
\text { (Check One) }\end{array}$} & \multirow{2}{*}{$\begin{array}{l}\text { Task Check } \\
\text { Point (CP) } \\
\text { Task Hold } \\
\text { Point (HP) } \\
\end{array}$} \\
\hline & & & & $\begin{array}{c}\text { Stockpile/ } \\
\text { Source }\end{array}$ & $\begin{array}{l}\text { Per Lift } \\
\text { Typical }\end{array}$ & Yes & No & \\
\hline \multirow[t]{4}{*}{$\begin{array}{c}\text { General } \\
\text { Information }\end{array}$} & \multicolumn{8}{|c|}{ GENERAL INSPECTIONS/OBSERVATIONS - See Specification Sections 01050 and 01400} \\
\hline & $\begin{array}{l}\text { General project } \\
\text { support }\end{array}$ & $\begin{array}{l}\text { Visual, plus basic measurements, } \\
\text { include survey/material data where } \\
\text { applicable }\end{array}$ & $\begin{array}{l}100 \% \text { during } \\
\text { construction }\end{array}$ & yes & yes & & & \\
\hline & $\begin{array}{l}\text { Lift/layer } \\
\text { thickness }\end{array}$ & Grade check lift thickness, as required & $\begin{array}{l}\text { As required per } \\
\quad \text { liftlayer } \\
\text { (see check points) }\end{array}$ & N/A & yes & & & \\
\hline & $\begin{array}{l}\text { As-built } \\
\text { topographic } \\
\text { survey }\end{array}$ & $\begin{array}{l}\text { Survey check: thickness, elevations, } \\
\text { slopes, as required }\end{array}$ & $\begin{array}{l}\text { As required per } \\
\text { construction phase } \\
\text { (see hold points) }\end{array}$ & N/A & yes & & & \\
\hline \multirow[t]{2}{*}{1} & \multicolumn{8}{|c|}{ RADIOLOGICALLY IMPACTED SOIL EXCAVATION (13 LOCATIONS) -- See Specification Section 02222} \\
\hline & $\begin{array}{l}\text { Removal of } \\
\text { contaminated soil. }\end{array}$ & $\begin{array}{l}\text { Locate and remove surface } \\
\text { contamination as described on the } \\
\text { drawings. }\end{array}$ & None & yes & $\mathrm{N} / \mathrm{A}$ & & & $\mathrm{CP}$ \\
\hline
\end{tabular}




\begin{tabular}{|c|c|c|c|c|c|c|c|c|}
\hline \multirow[b]{2}{*}{$\begin{array}{c}\text { Construction } \\
\text { Phase } \\
\end{array}$} & \multirow[b]{2}{*}{ SITA Task } & \multirow[b]{2}{*}{ SITA Method(s) } & \multirow{2}{*}{$\begin{array}{c}\begin{array}{c}\text { Sample/Test } \\
\text { Quantity/Frequency }\end{array} \\
\text { Other Instructions }\end{array}$} & \multicolumn{2}{|c|}{$\begin{array}{l}\text { Sample/Location/ } \\
\text { Requirement }\end{array}$} & \multicolumn{2}{|c|}{$\begin{array}{c}\text { Task } \\
\text { Acceptance } \\
\text { (Check One) }\end{array}$} & \multirow{2}{*}{$\begin{array}{l}\text { Task Check } \\
\text { Point (CP) } \\
\text { Task Hold } \\
\text { Point (HP) }\end{array}$} \\
\hline & & & & $\begin{array}{c}\text { Stockpile/ } \\
\text { Source }\end{array}$ & $\begin{array}{l}\text { Per Lift } \\
\text { Typical }\end{array}$ & Yes & No & \\
\hline & Disposal & $\begin{array}{l}\text { Material to be placed in a B25 box } \\
\text { and shipped to the Area } 3 \text { RWMS for } \\
\text { Disposal. }\end{array}$ & $\begin{array}{l}\text { After excavation } \\
\text { completion }\end{array}$ & N/A & N/A & & & $\mathrm{HP}$ \\
\hline
\end{tabular}




\section{SECTION II}

SITA Plan Table II

\section{Site: Roller Coaster Radsafe Area: Waste Disposal Pit -- Closure Tasks}

REVISION: $\quad 0$

DATE: $\underline{05 / 09 / 00}$

General instructions for using the SITA Plan Table and Guides:

1. For sampling/testing activities specified herein, use the appropriate SITA Guide Sheet.

2. All sampling/testing locations will be random and shown on the appropriate SITA Guide Sheet.

3. Acceptance and/or approval will be made by one (or more) of the SITA delegates (see Section I, Part 2.2 and Part 5.0 for guidance)

4. All HPs must be initialed by the responsible SITA delegate prior to continuance to the next phase of construction.

\begin{tabular}{|c|c|c|c|c|c|c|c|c|}
\hline \multirow[b]{2}{*}{$\begin{array}{c}\text { Construction } \\
\text { Phase }\end{array}$} & \multirow[b]{2}{*}{ SITA Task } & \multirow[b]{2}{*}{ SITA Method(s) } & \multirow{2}{*}{$\begin{array}{c}\text { Sample/Test } \\
\text { Quantity/Frequency } \\
\text { Other Instructions } \\
\end{array}$} & \multicolumn{2}{|c|}{$\begin{array}{l}\text { Sample/Location/ } \\
\text { Requirement }\end{array}$} & \multicolumn{2}{|c|}{$\begin{array}{c}\text { Task } \\
\text { Acceptance } \\
\text { (Check One) } \\
\end{array}$} & \multirow{2}{*}{$\begin{array}{l}\begin{array}{l}\text { Task Check } \\
\text { Point (CP) }\end{array} \\
\text { Task Hold } \\
\text { Point (HP) }\end{array}$} \\
\hline & & & & \begin{tabular}{|l} 
Stockpile/ \\
Source
\end{tabular} & $\begin{array}{l}\text { Per Lift } \\
\text { Typical } \\
\end{array}$ & Yes & No. & \\
\hline \multirow[t]{3}{*}{$\begin{array}{c}\text { General } \\
\text { Information }\end{array}$} & \multicolumn{8}{|c|}{ GENERAL INSPECTIONS/OBSERVATIONS -- See Specification Sections 01050 and 01400} \\
\hline & $\begin{array}{l}\text { General project } \\
\text { support }\end{array}$ & $\begin{array}{l}\text { Visual, plus basic measurements, } \\
\text { include survey/material data where } \\
\text { applicable }\end{array}$ & $\begin{array}{l}100 \% \text { during } \\
\text { construction }\end{array}$ & yes & yes & & $!$ & \\
\hline & $\begin{array}{l}\text { Lift/layer } \\
\text { thickness }\end{array}$ & Grade check lift thickness, as required & $\begin{array}{l}\text { As required per } \\
\text { lift/layer } \\
\text { (see check points) }\end{array}$ & N/A & yes & & & \\
\hline & $\begin{array}{l}\text { As-built } \\
\text { topographic } \\
\text { survey }\end{array}$ & $\begin{array}{l}\text { Survey check: thickness, elevation, } \\
\text { slope, as required }\end{array}$ & $\begin{array}{l}\text { As required per } \\
\text { construction phase } \\
\text { completion } \\
\text { (see hold points) }\end{array}$ & N/A & yes & & & \\
\hline 1 & \multicolumn{8}{|c|}{ NATIVE MATERIAL FILL PLACEMENT - See Specification Section 02223 and SITA Guide No. 4} \\
\hline & $\begin{array}{l}\text { As-built grade } \\
\text { check }\end{array}$ & $\begin{array}{l}\text { Grade check: thickness, elevations, } \\
\text { slopes, as required }\end{array}$ & $\begin{array}{c}\text { After each lift } \\
\text { placement completion }\end{array}$ & N/A & Yes & & & $\mathrm{CP}$ \\
\hline
\end{tabular}




\begin{tabular}{|c|c|c|c|c|c|c|c|c|}
\hline \multirow[b]{2}{*}{$\begin{array}{c}\text { Construction } \\
\text { Phase } \\
\end{array}$} & \multirow[b]{2}{*}{ SITA Task } & \multirow[b]{2}{*}{ SITA Method(s) } & \multirow{2}{*}{$\begin{array}{c}\begin{array}{c}\text { Sample/Test } \\
\text { Quantity/Frequency }\end{array} \\
\text { Other Instructions } \\
\end{array}$} & \multicolumn{2}{|c|}{$\begin{array}{c}\text { Sample/Location/ } \\
\text { Requirement }\end{array}$} & \multicolumn{2}{|c|}{$\begin{array}{c}\text { Task } \\
\text { Acceptance } \\
\text { (Check One) }\end{array}$} & \multirow{2}{*}{$\begin{array}{l}\text { Task Check } \\
\text { Point (CP) } \\
\text { Task Hold } \\
\text { Point (HP) } \\
\end{array}$} \\
\hline & & & & $\begin{array}{c}\text { Stockpile/ } \\
\text { Source }\end{array}$ & $\begin{array}{l}\text { Per Lift } \\
\text { Typical }\end{array}$ & Yes & No & \\
\hline & $\begin{array}{l}\text { As-built grade } \\
\text { check }\end{array}$ & $\begin{array}{l}\text { Grade check: thickness, elevations, } \\
\text { slopes, as required }\end{array}$ & $\begin{array}{c}\text { After each lift } \\
\text { placement completion }\end{array}$ & N/A & Yes & & & $\mathrm{CP}$ \\
\hline & $\begin{array}{l}\text { As-built } \\
\text { topographic } \\
\text { survey }\end{array}$ & $\begin{array}{l}\text { Survey check: thickness, elevations, } \\
\text { slopes, as required }\end{array}$ & $\begin{array}{l}\text { After layer placement } \\
\text { completion }\end{array}$ & N/A & Yes & & & HP \\
\hline \multirow[t]{4}{*}{2} & \multicolumn{8}{|c|}{ FENCING, AND SIGNAGE PLACEMENT -- See Specification Sections 02831 and 03001} \\
\hline & Fencing & Installation & Completion & N/A & N/A & & & $\mathrm{CP}$ \\
\hline & Signage & Installation & Completion & N/A & N/A & & & $\mathrm{CP}$ \\
\hline & Survey & $\begin{array}{c}\text { Cap surface - final topographic survey } \\
\text {-- as-built drawings }\end{array}$ & Final & N/A & N/A & & & HP \\
\hline \multirow[t]{2}{*}{3} & \multicolumn{8}{|c|}{ VEGETATIVE LAYER PROCEDURE (Placed Stabilization Layer Material) } \\
\hline & $\begin{array}{l}\text { Prepare Cover } \\
\text { Only }\end{array}$ & $\begin{array}{l}\text { Site Prep: Prior to Placement of any } \\
\text { Vegetation disc/plow cover surface. }\end{array}$ & None & N/A & N/A & & & $\mathrm{HP}$ \\
\hline \multirow[t]{3}{*}{4} & \multicolumn{8}{|c|}{ RCRSA CMP CLOSURE CAP CONSTRUCTION COMPLETION - See Specification Sections 01700 and 01720} \\
\hline & $\begin{array}{l}\text { Site tour } \\
\text { confirmation }\end{array}$ & $\begin{array}{l}\text { Establish with DOE/PM (and notify } \\
\text { NDEP) closure acceptance tour } \\
\text { date/time }\end{array}$ & None & N/A & N/A & & & $\mathrm{HP}$ \\
\hline & Site tour & Closure acceptance/Sign-off & Final & N/A & N/A & & & $\mathrm{HP}$ \\
\hline
\end{tabular}


SECTION III

\section{ENGINEERING DRAWINGS}




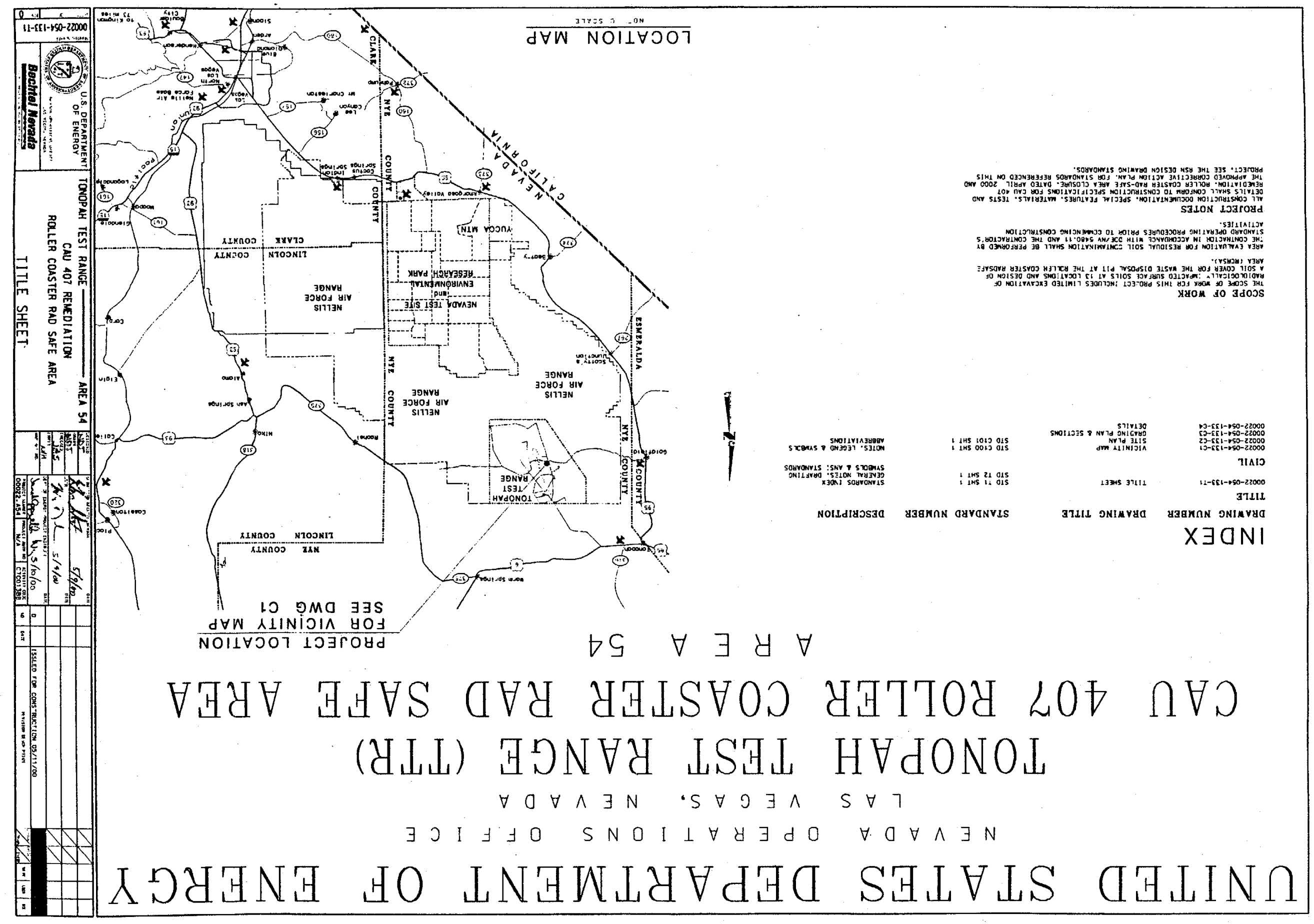



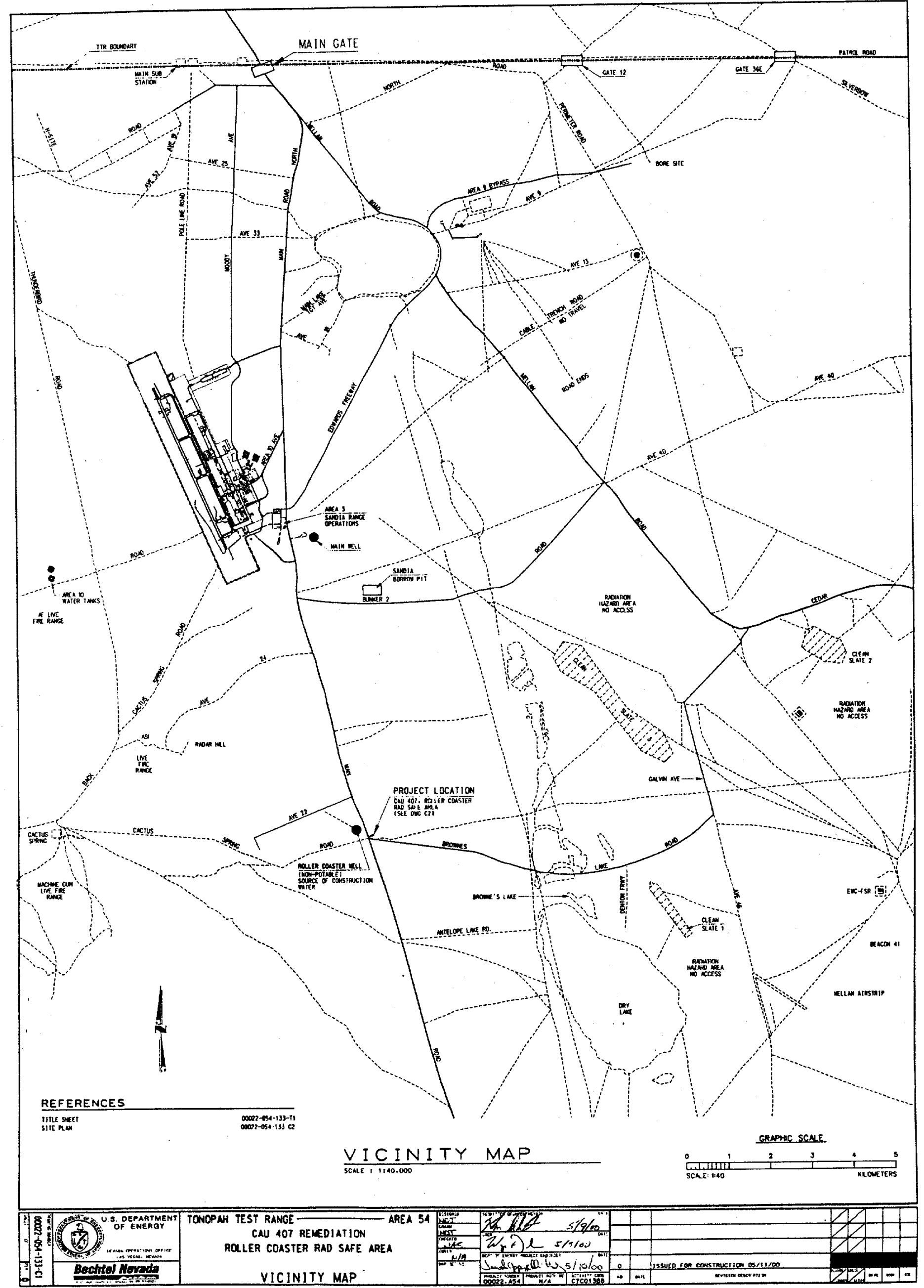


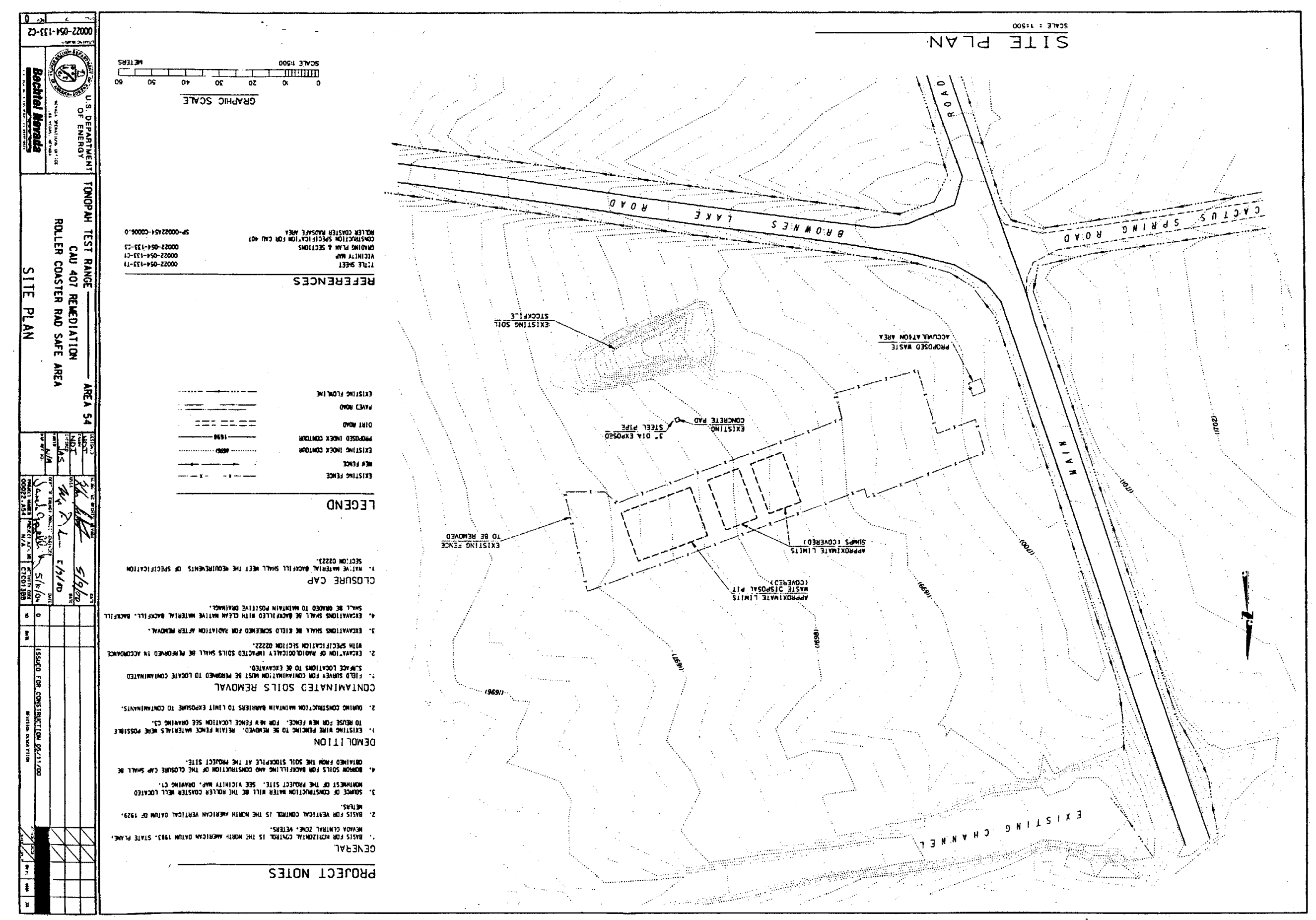



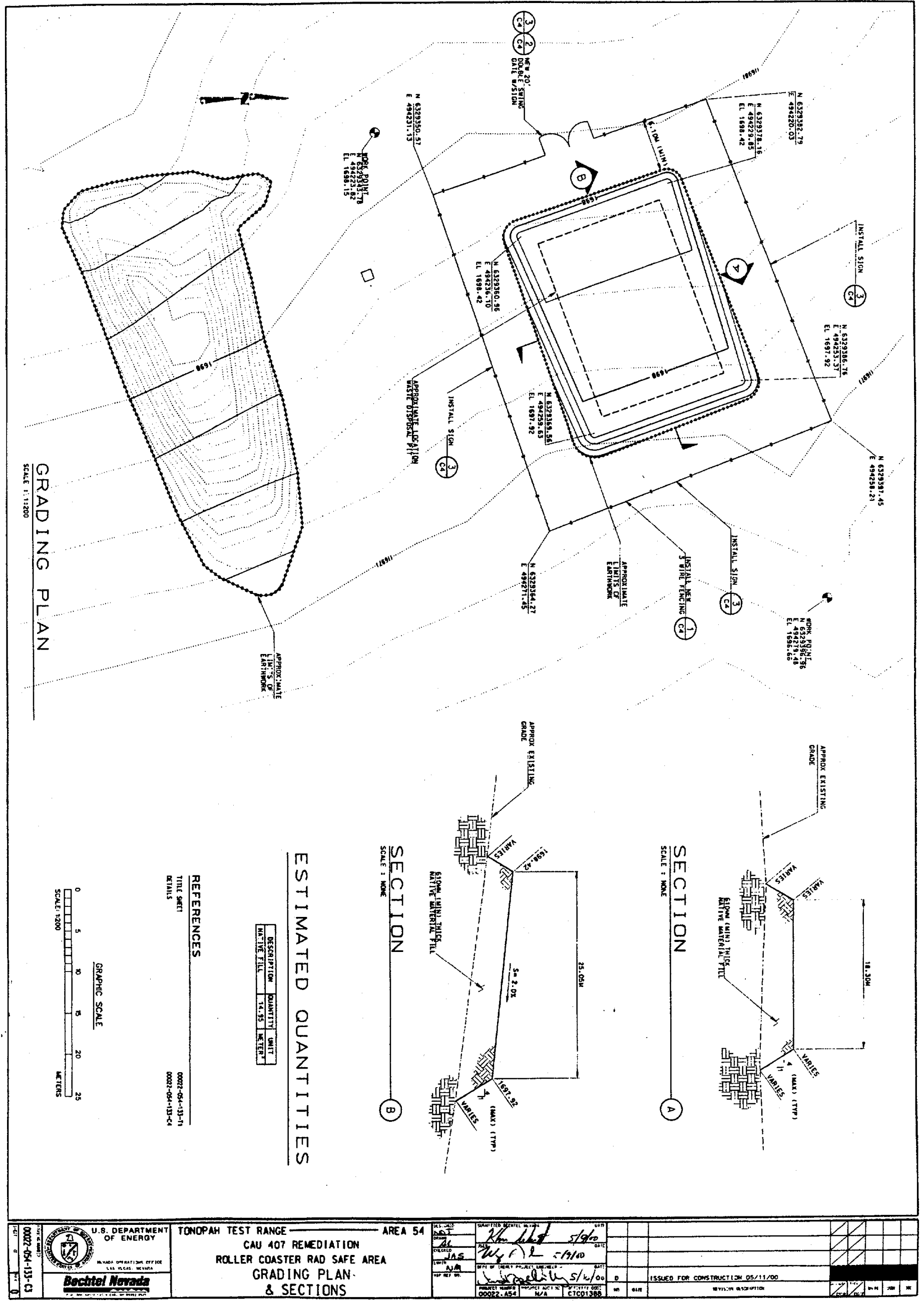

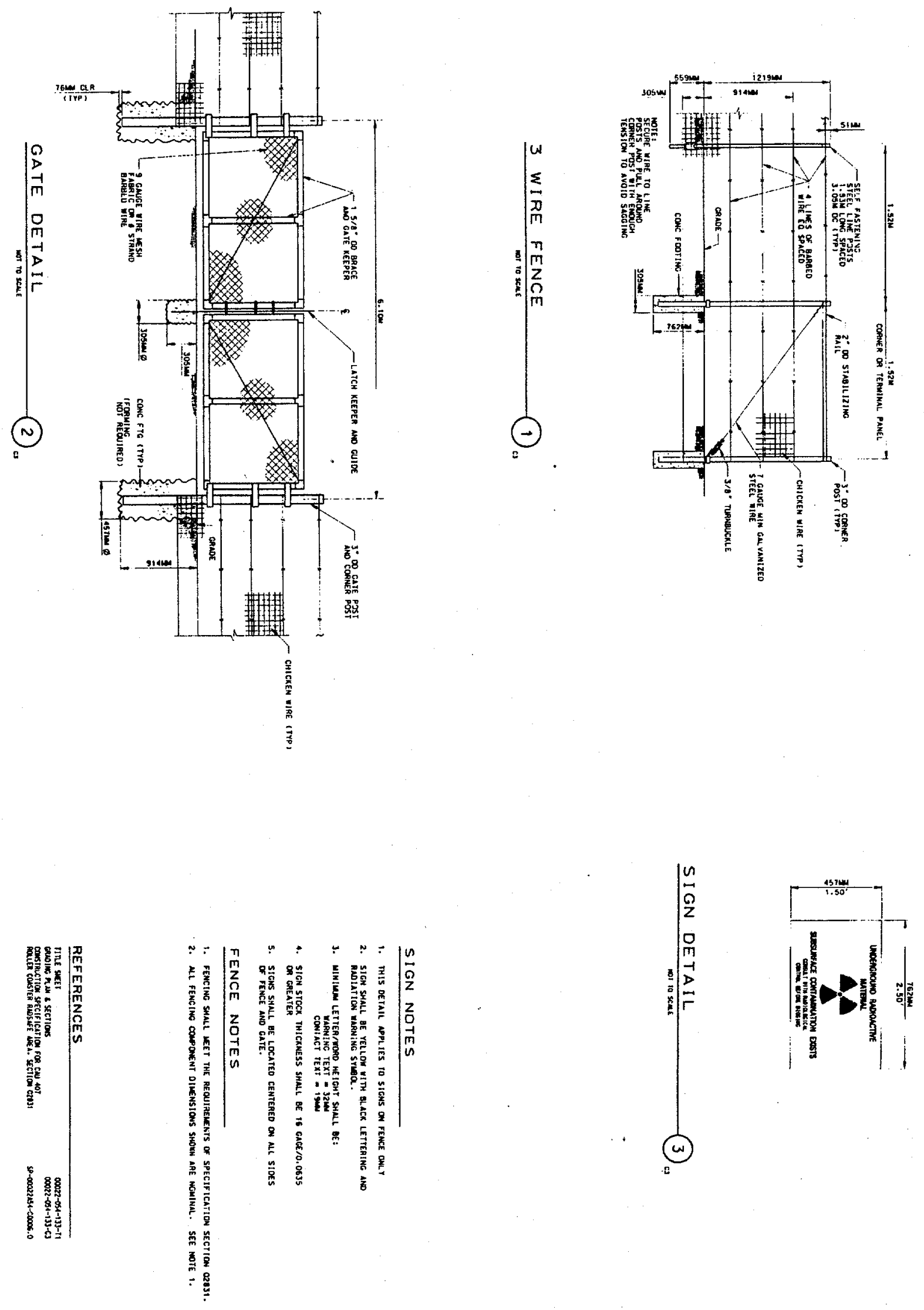

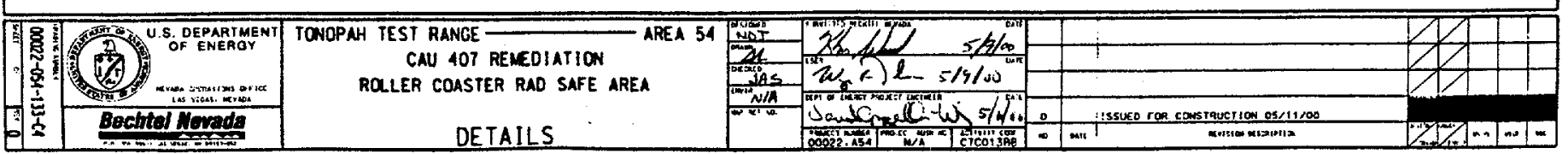




\section{SECTION IV}

\section{CONSTRUCTION SPECIFICATION}




\section{CONSTRUCTION \\ SPECIFICATIONS \\ FOR \\ CAU 407 REMEDIATION \\ ROLLER COASTER \\ RAD-SAFE AREA CLOSURE}

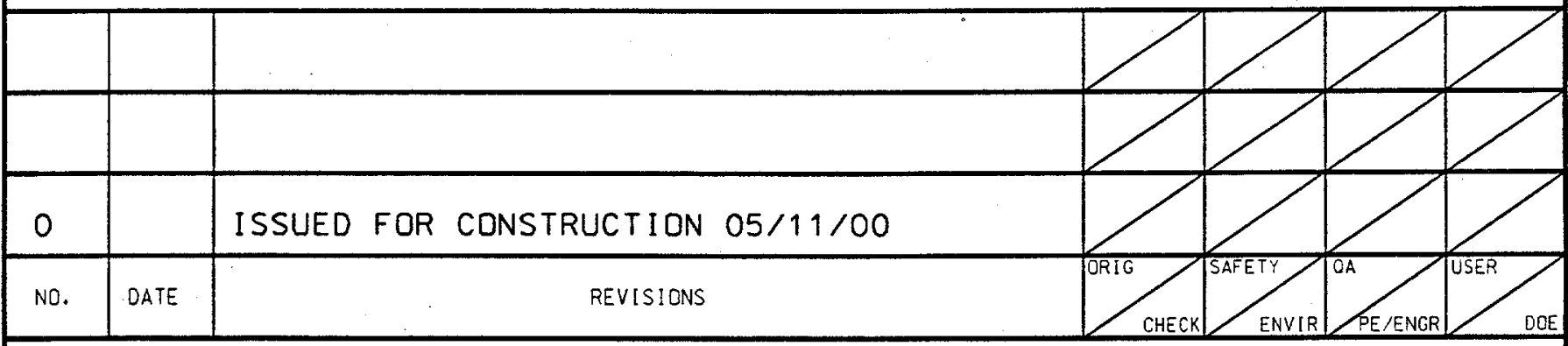

U.S. DEPARTMENT OF ENERGY

NEVADA DPERATIONS OFFICE

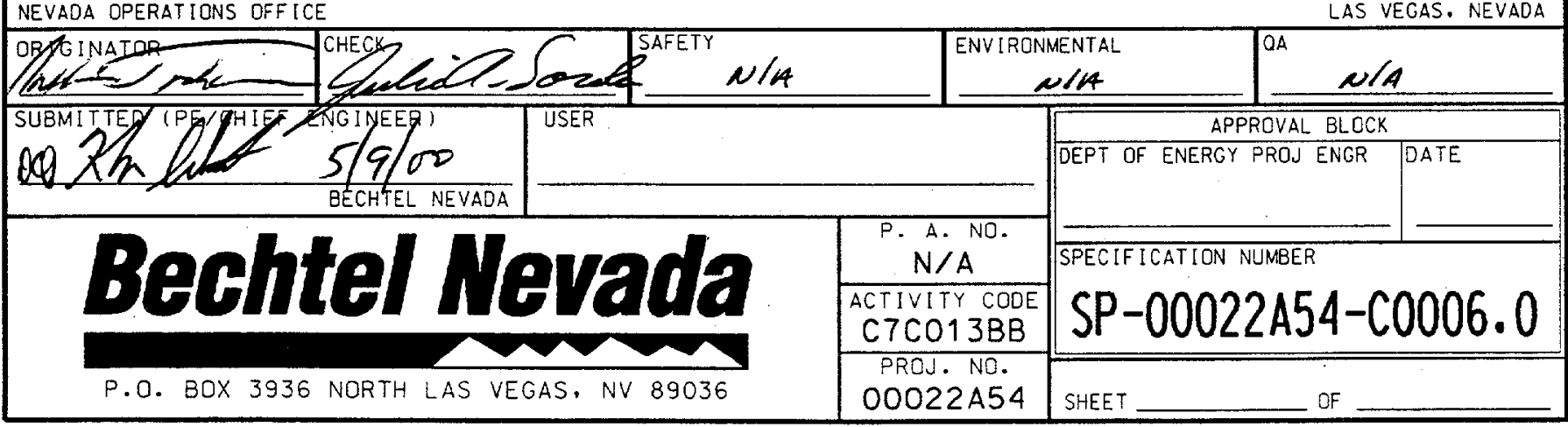




\section{CONSTRUCTION SPECIFICATIONS FOR}

\section{CAU 407 REMEDIATION \\ ROLLER COASTER RADSAFE AREA CLOSURE}

PREPARED BY:

BECHTEL NEVADA

MAY, 2000 


\section{CONSTRUCTION SPECIFICATIONS \\ FOR \\ CAU 417 REMEDIATION \\ UC1-CMP CLOSURE}

TABLE OF CONTENTS

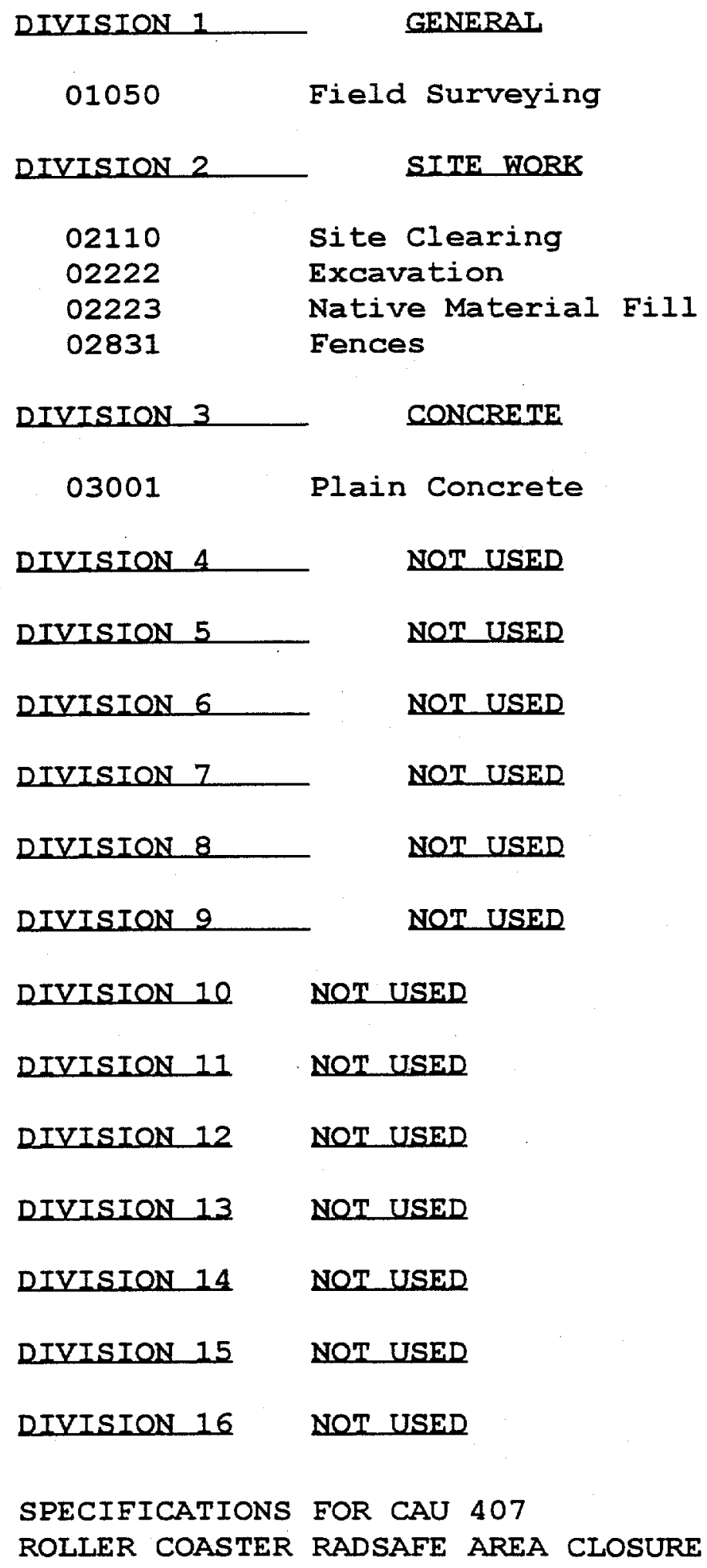


1.01 Work Included

1.02 Related Work

1.03 References

1.04 Quality Assurance

$\begin{array}{ll}\text { PART } 2 \text { PRODUCTS } & 1\end{array}$

2.01 Project Record Documents 


\section{SECTION 01050}

FIELD SURVEYING

PART 1 GENERAL

1.01 WORK INCLUDED

A. Field Engineering Services

B. Surveys for acceptance and final construction as-built

1.02 RELATED WORK

Not used

1.03 REFERENCES

Not used

1.04 QUALITY ASSURANCE

A. Surveyor: The field survey data will be reviewed by a registered Land Surveyor.

PART 2 PRODUCTS

2.01 PROJECT RECORD DOCUMENTS

A. Survey shall maintain and complete, accurate field log-book of project established controls and survey work as project progresses through final as-built:

B. Location and thickness information shall be recorded on lift diagram.

1. Record approximate overall dimensions of lift, thickness of lift, approximate locations of thickness measurements.

2. Record coordinate locations of grade stakes set for thickness measurements (if required) and target/final elevations at each grade stake location.

C. All survey requirements and documentation shall be performed as indicated in the approved Sampling, Inspection, Testing, and Acceptance (SITA) Plan. 
D. Submit survey information showing dimensions, coordinate locations, and elevations for the final surface of the closure as shown on the engineering drawings and/or sketches.

1. Data shall be submitted to the SITA Engineering Delegate.

2. Data shall be submitted in ASCII file format and contain sufficient data points to create digital terrain models of each closure component to facilitate as-builting of the Project Drawings.

END OF SECTION 
TABLE OF CONTENTS

RARAGRAPH

TITIE

PART 1 GENERAI

1

1.01 Work Included

1

1.02 Related Work

PART 2 PRODUCTS (NOT USED)

1

1

1

1

1

2 
SECTION 02110

SITE CLEARING

PART 1 GENERAL

1.01 WORK INCLUDED

A. Removal of surface debris

B. Removal of plants and grass

C. Removal of root systems

1.02 RELATED WORK

A. Section 02222 - Excavation

PART 2 PRODUCTS

NOT USED

PART 3 EXECUTION

3.01 PREPARATION

A. Verify that existing plant life and features designated to remain are tagged or identified.

3.02 PROTECTION

A. Protect bench marks and existing work from damage or displacement.

B. Notify the Construction Superintendent immediately when existing utility lines, or other man-made objects whether or not shown on the Drawings, are encountered or damaged. See section 02222 for goldaking guidance.

C. Apply water as necessary to control dust and maintain air quality in conformance with applicable local, state, and federal regulations.

3.03 CLEARING

A. Clear areas required for access to site and execution of work. 
B. Remove shrubs and grass within marked areas. Remove main root balls and root systems, to a depth of 18 inches $(457 \mathrm{~mm})$.

C. Remove rocks and boulders larger than 6 inches (152 $\mathrm{mm})$ in diameter, as directed by the Construction Superintendent.

3.04 REMOVAL

A. Remove debris, rocks, and extracted plant life from site.

B. Relocate all debris to a site as directed by the Construction Superintendent.

c. Burning of waste materials on the site will not be permitted.

END OF SECTION 
TABLE OF CONTENTS

PARAGRAPH

PART 1 GENERAL

1.01 Work Included

1.02 Related Work

1.03 References

1.04 Quality Assurance

1.05 Protection

PART 2 PRODUCTS

2.01 Materials

2.02 Equipment

PART 3 EXECUTION

3.01 Preparation

3.02 Excavation

3.03 Compaction
TITLE

PAGE NO.

1

1

1

1

1

1

2

2

2

2

2

2

3 


\section{PART 1 GENERAL}

1.01 WORK INCLUDED

A. Excavation of radiologically impacted soils.

B. Excavation of soil stockpile.

1.02 RELATED WORK

A. Section 01050 - Field Surveying

B. Section 02223 - Native Material Fill

\subsection{REFERENCES}

A. Code of Federal Regulations (CFR) 29 CFR:

OSHA. 1926 Safety and Health Regulations for Construction

\subsection{QUALITY ASSURANCE}

Inspections/Observations shall be performed to verify compliance with Parts 3.02 and 3.03 of this specification in accordance with the approved Sampling, Inspection, Testing, and Acceptance (SITA) Plan.

\subsection{PROTECTION}

A. Notify the Construction Superintendent of unexpected subsurface conditions and discontinue affected work in area until notified to resume work.

B. The exact location and depth of burial of unidentified utilities or man made objects (if any encountered) shall be confirmed/documented (goldaking) by the Construction Superintendent and provided to the site supervisor. 
PART 2 PRODUCTS

2.01 MATERIAIS

A. Radiologically Impacted Soils

1. Excavated contaminated soils shall be containerized and shipped to the Area 3 RWMS at the NTS for disposal, per the SITA plan.

B. Soil Stockpile (Native Material Backfill)

1. Excavated native material shall be obtained from locations shown on the drawings.

2. Native material from excavations shall be stockpiled until required, or transported directly for cover construction.

2.02 EQUIPMENT

A. Equipment shall meet the applicable requirements of OSHA 1926

PART 3 EXECUTION

3.01 PREPARATION

A. Identify required lines, levels, contours, and datum. See Section 01050.

B. Check, as required, and mark any unidentified buried utilities/manmade objects before any excavation work begins. Utilize any existing goldaking documents to minimize additional efforts.

3.02 EXCAVATION

A. Radiologically Impacted Soils

1. Survey shall locate contaminated soils to be removed.

2. Excavations shall be approximately $2.0^{\prime}(610 \mathrm{~mm}$ ) squiare and 6" (152 $\mathrm{mm})$ deep.

3. Field screen areas for radiation after soil removal.

B. Soil Stockpile (Native Material Backfill) 
1. Verify that excavation grade slope banks do not exceed OSHA 1926 requirements.

2. Remove all lumped subgrade soil and rocks over 6 inches $(152 \mathrm{~mm})$ in diameter.

3. Perform excavations such that adequate drainage is maintained.

4. Use the excavations to obtain required native material fill.

a. Dispose of overburden and other spoil materials as directed by the Construction Superintendent.

b. Trim the side slopes neatly after the excavation is completed.

5. Stockpile excavated material in an area designated by the construction superintendent.

6. Stockpile excavated borrow material to a height not exceeding 15 feet $(4.57 \mathrm{~m})$.

\subsection{COMPACTION}

A. Radiologically Impacted Soils

1. No compaction required.

B. Soil Stockpile (Native Material Backfill)

1. No compaction required.

\section{END OF SECTION}


TABLE OF CONTENTS

PARAGRAPH

TITLE

RAGE NO.

PART 1 GENERAL

1.01 Work Included

1

1.02 Related Work

1

1.03 References

1

1.04 Quality Assurance

PART 2 PRODUCTS

2.01 Materials

1

2.02 Equipment

PART 3 EXECUTION

3.01 Inspection

3.02 Eqipment

3.03

Placement

2

3.04 Field Quality control 
SECTION 02223

NATIVE MATERIAI FILI

PART 1 GENERAL

1.01 WORK INCLUDED

A. Native Material Fill

1.02 REIATED WORK

A. Section 02222 - Excavation

1.03 REEERENCES

A. American Society for Testing and Materials (ASTM): ASTM D2487-98 Standard Classification of Soils for Engineering Purposes (Unified Soil Classification System).

B. Code of Federal Regulations (CFR) 29 CFR:

OSHA 1926 Safety and Health Regulations for Construction

1.04 QUALITY ASSURANCE

A. Inspection/Observation Personnel shall be as stated in the approved Sampling, Inspection, testing, and Acceptance (SITA) Plan.

\section{PART 2 PRODUCTS}

\subsection{MATERIALS}

A. Fill material shall be excavated native material obtained from excavations as shown on the drawings.

1. Native Material Fill: Material shall be a well graded, natural soil containing not more than 50 percent fines, with rocks larger than 6 inches, brush, roots, and all debris removed. Well graded shall be per ASTM D2487, where the sieve opening passing 60 percent of the material is 4 or more times greater than the size passing 10 percent of the material. 
2.02 EQUIPMENT

A. Equipment shall meet the applicable requirements of OSHA 1926

PART 3 EXECUTION

3.01 INSPECTION

A. Documentation shall be in accordance with the approved SITA Plan.

B. Verify that areas to be backfilled are free of debris, water, and rocks larger than 6 inches.

C. Verify that all items under Part 3.04 are complete after placement of each lift of fill material.

3.02 EQUIPMENT

A. Fill materials shall be placed with standard earth moving equipment.

3.03 PLACEMENT

A. Native Material Fill:

1. Layer material shall be placed in continuous 6 inch (152 mm) minimum, 12 inch (305 $\mathrm{mm}$ ) maximum completed lifts.

2. After all Native Material Fill lifts have been placed and all lift thickness requirements have been accepted, approved, and documented, the following shall be performed:

a. The entire surface of the Native Material Fill shall be graded to achieve a uniform slope as shown on the drawings.

3.04 FIELD QUALITY CONTROL

A. GRADE CONTROL

1. Final grade slope will be as indicated on the drawings and the tolerance shall be minus $0 \%$ to plus $1.5 \%$.

B. THICKNESS CONTROL 
1. Iift thickness shall be verified and documented per section II of the approved SITA Plan, and specification section 01050.

C. INSPECTION

1. Inspection/observations shall be performed and documented as indicated in section II of the approved SITA Plan.

END OF SECTION 
TABLE OF CONTENTS

PART 1 GENERAL

1.01 Work Included

1

1.02 Related Work

1

1.03

References

1.04

Quality Assurance

1

PART 2 PRODUCTS

1

2.01 Barbed Wire Fence

2.02 Concrete

1

2

PART 3 EXECUTION

2

3.01 General

3.02 Barbed Wire Fence

3.03 Signs

2 


\section{FENCES}

PART 1 GENERAL

1.01 WORK INCLUDED

A. Barbed wire fencing

B. Gates

1.02 RELATED WORK

A. Section 03001 - Plain Concrete

1.03 REFERENCES

A. American Society for Testing and Materials (ASTM) : ASTM A121-92 Standard Specification for zinc-Coat Rev A (Galvanized) steel barbed wire

ASTM A123-89 Standard Specification for Zinc (Hot-Dip Rev A Galvanized) Coatings on Iron and steel Products

B. Federal Specifications (FS) :

FS RR-F-183 Fence Posts, Gates, and Accessories

FS RR-F-221 Fencing Wire (Barbed Wire, Woven Wire, and Netting) Fence Posts and Accessories

1.04 QUATITY ASSURANCE

NOT USED

PART 2 PRODUCTS

2.01 BARBED WIRE FENCE

A. Wire: furnish barbed wire consisting of two twisted strands of 12 1/2 gauge wire, with 4 point barbs spaced not more than 5 inches $(127 \mathrm{~mm})$ apart conforming to FS $R R-F-221$.

B. Posts: furnish drive-type and corner/end-type posts for barbed wire fencing of the length shown on the Drawings.

C. Coatings: galvanized coating is standard for barbed wire, gate assemblies, and corner/end posts. Galvanized coating for drive-type (intermediate) posts is preferred. 
D. Fencing components size, shape, and dimensions vary by manufacturer. Nominal information is indicated on the drawings, and the selected vendor may provide alternate sizes, shapes, and dimensions of fencing components.

2.02 CONCRETE

A. Furnish an approved, pre-mixed concrete having a compressive strength of $2,000 \mathrm{psi}$ (14 MPa) at 28 days as specified in section 03001 . Testing is not required.

\section{PART 3 EXECUTION}

3.01 GENERAL

A. Grading

1. The ground along the fence line shall be graded such that the vertical clearance between bottom of lower fence strand and ground will not be less than 6 inches $(153 \mathrm{~mm})$ unless otherwise shown on the Drawings or approved by the Construction Supervisor.

B. Excavation

1. Excavation for posts and other concrete-embedded Items shall be of the dimensions indicated on the Drawings.

2. Waste material from excavation shall be spread where directed.

3. Post holes to receive concrete shall be thoroughly cleared of loose material.

C. Footings

1. Footing dimensions for corners and end (terminal) posts shall be as shown on the project/standard drawings.

2 Finish concrete footings by neatly shaping at the finish grade line to provide shedding of water away from the posts.

3.02 BARBED WIRE FENCE

A. Erection

1. Assemble and erect fences as specified and in accordance with detailed instructions furnished by the fencing manufacturer. 
B. Fence posts

1. Drive posts shall be spaced as shown on the Drawings and driven to the depth required to provide the fence height indicated.

2. Corner and end posts shall be installed as shown on the drawings and/or manufacturers instructions.

3. Cut posts, if required, to achieve fence helght specified on the drawings.

C. Barbed wire

1. Barbed wire shall be spaced as indicated to provide the number of strands shown on the Drawings.

2. Barbed wire shall be fastened as required by the types of posts used in the fence assembly.

3. Chicken wire shall be attached to the outside of the barbed wire fence. Wire shall extend 3 feet (914mm) above grade and be embedded a minimum of 1 foot ( $305 \mathrm{~mm})$ below grade.

D. Gates

1. Gates shall be of the design indicated on the Drawings, or as approved by the manufacturer.

2. Gate security hinges shall have tight, nonremovable pins; latches shall be provided with means for padlocking.

\subsection{SIGNS}

A. All signs to be installed on the fence shall be at the locations shown on the drawings.

B. Signage size, type, and color of letters shall be as shown on the drawings.

END OF SECTION 
TABLE OF CONTENTS

PARAGRAPH

TITLE

RAGE NO.

PART 1 GENERAL

1.01 Work Included

1.02 Related Work

1.03 References

1.04 Quality Control

PART 2 PRODUCTS

1

2.01 Concrete Materials

2.02 Concrete $\mathrm{Mix}$

PART 3 EXECUTION

1

1

1

1

1

2

2

3.01 Placing Concrete

3.02 Finishing

3.03 Curing (Survey Location Monuments Only)

3.04 Concrete Inspection

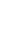

1

(1)

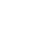

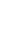




\section{SECTION 03001}

PLAIN CONCRETE

PART 1 GENERAL

1.01 WORK INCLUDED

A. Concrete for Fence Footings

B. Concrete for Survey Location Monuments

1.02 RELATED WORK

A. Section 02831 Fences

1.03 REFERENCES

A. American Concrete Institute (ACI):

ACI 301-89structural Concrete for Buildings

ACI 305R-91 Hot Weather Concreting

ACI 306R-88 Cold Weather Concreting

B. American Society for Testing and Materials (ASTM) :

ASTM C33-93 Standard Specification for Concrete Aggregates

ASTM C94-92 Standard Specification for Ready-Mixed Concrete

ASTM C150-92 Standard Specification for Portland Cement

1.04 QUALITY CONTROL

A. Perform work in accordance with ACI 301 .

B. Hot weather concreting shall be in accordance with ACI 305R-91. Cold weather concreting shall be in accordance with ACI 306R-88.

PART 2 PRODUCTS

2.01 CONCRETE MATERIALS

A. Use one brand and type of pre-mixed concrete throughout project unless otherwise shown on the Drawings.

B. Cement (used in pre-mixed concrete)-conforming to ASTM C150, Type II, No color required. 


\subsection{CONCRETE MIX}

A. Provide an approved, Pre-mixed concrete having a compressive strength of $2,000 \mathrm{psi}(14 \mathrm{MPa})$ in 28 days unless otherwise shown on the Drawings. Testing is not required.

\section{PART 3 EXECUTION}

3.01 PLACING CONCRETE

A. Place concrete in accordance with ACI 301 .

B. Verify that fence posts are in place and kept vertical.

3.02 FINISHING

A. Concrete finishes

1. Dusting of finish surfaces with dry materials will not be permitted.

2. Additions of water to finish surfaces will not be permitted.

3. Survey location monument finishing

a. Screed and float concrete with straight edges to bring surface to required level with no coarse aggregate visible.

b. Float concrete while still soft to a true, even plane.

c. Trowel surfaces to required finish after surface moisture has disappeared, leaving no coarse aggregate visible.

4. Fence post footing finishing

a. Slope top surface to drain away from fence post.

\subsection{CURING (SURVEY LOCATION MONUMENTS ONLY)}

A. Protect from moisture loss all concrete surfaces not covered by forms.

1. Begin curing immediately after finishing.

2. Cure for not less than seven days.

3. Shade concrete surfaces from direct sun during the curing period.

4. Keep surfaces free of any traffic (foot or vehicle) during the curing period. 
B. Curing shall be accomplished by the following method. 1. Curing Compound

3.04 CONCRETE INSPECTION

A. Inspect all concrete surfaces immediately after pouring concrete.

B. Excessive honeycomb or embedded debris in concrete is not acceptable and must be replaced.

C. Modify or replace concrete not conforming to required levels and lines, details, and elevations.

D. Repair or replace concrete not properly placed or not of the specified type.

EHD OF SECTION 
APPENDIX A-2

PROJECT ORGANIZATION 
$\square$

๘

a

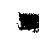

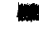



.

THIS PAGE LEFT INTENTIONALLY BLANK

a

a 
The following are the DOE/NV project contacts:

Runore C. Wycoff

Director

Environmental Restoration Division

U.S. Department of Energy, Nevada Operations Office

P.O. box 98518

Las Vegas, NV 89193-8518

(702) 295-0250

Janet L. Appenzeller-Wing

Project Manager

Industrial Sites Project

U.S. Department of Energy, Nevada Operations Office

P.O. box 98518

Las Vegas, NV 89193-8518

(702) 295-0461

The identification of the project Health and Safety Officer and the Quality Assurance Officer can be found in the appropriate DOE plan. However, personnel are subject to change and it is suggested that the Project Manager be contacted for further information. The Task Manager will be identified in the FFACO Biweekly Activity Report prior to the start of field activities. 
THIS PAGE LEFT INTENTIONALLY BLANK 
APPENDIX B

FLOOD STUDY 



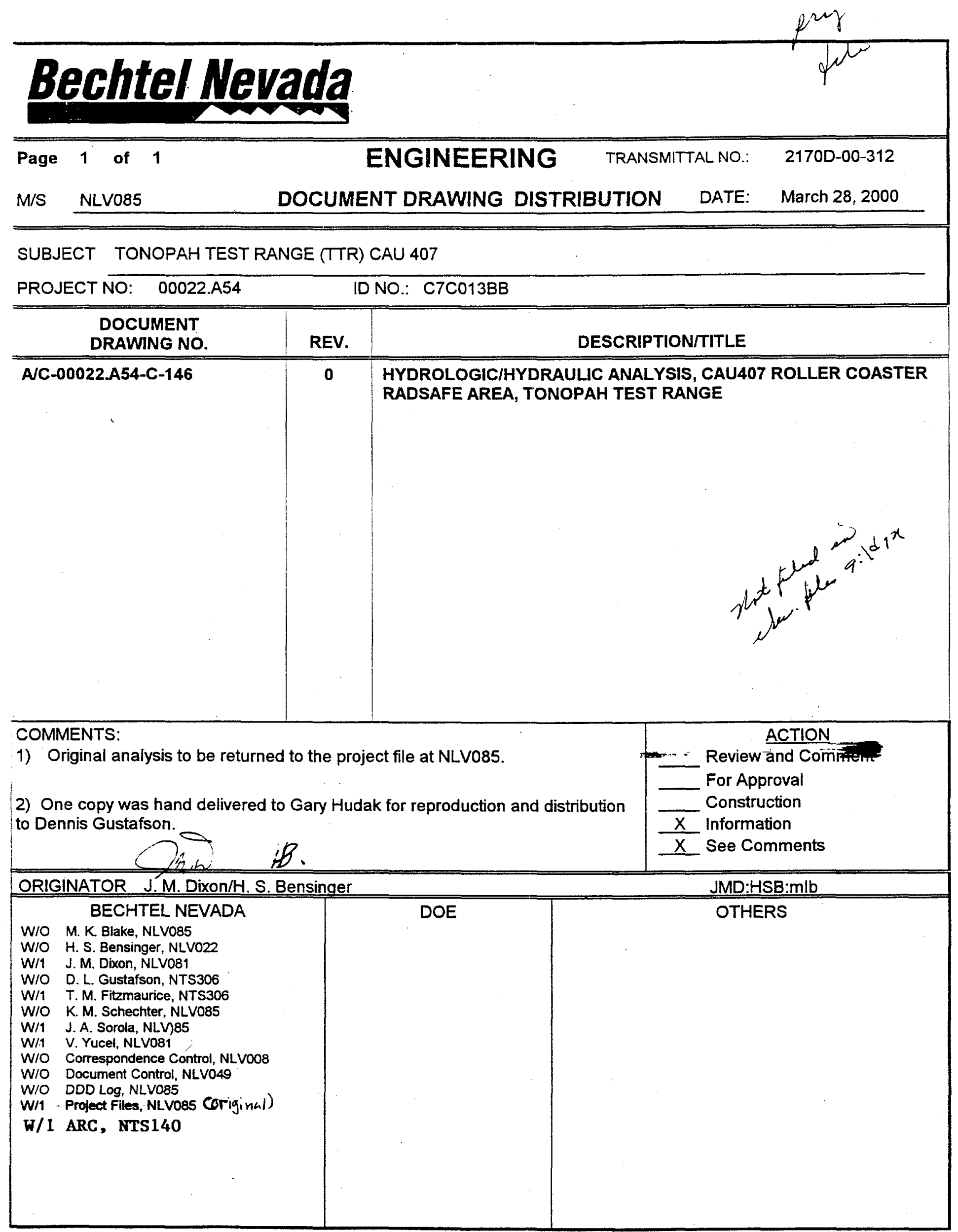


ANALYSIS / CALCULATION (A/C) COVER SHEET

\begin{tabular}{|c|c|c|c|c|}
\hline \multicolumn{2}{|c|}{$\begin{array}{l}\text { Project Title: } \\
\text { CAU } 407 \text { - Roller Coaster Radsafe Area, Tonopah Test Range }\end{array}$} & Projec & $\begin{array}{l}\text { cking No. } \\
\text { O22.A54 }\end{array}$ & $\begin{array}{l}\text { Analysis/Calculation No.: } \\
\text { A/C - 00022.A54-C-146 }\end{array}$ \\
\hline \multicolumn{5}{|l|}{$\begin{array}{l}\text { Subject: } \\
\text { Hydrologic/Hydraulic Analysis }\end{array}$} \\
\hline \multicolumn{2}{|c|}{ Analysis / Calculation Status Designation: } & iminary & $\mathbf{x}$ Final & Superseded \\
\hline Computer Program / Title & Mainframe / PC & Progran & & Version / Release No. \\
\hline HEC-1 Flood Hydrograph Package & PC & & & $4.1 / 1998$ \\
\hline Microsoft Excel & $P C$ & & & SR-2/1997 \\
\hline FlowMaster & PC & & & V5.3 \\
\hline CulvertMaster & $\mathrm{PC}$ & & & v1.0 \\
\hline
\end{tabular}

\subsection{INTRODUCTION}

The goal of this analysis is to evaluate potential flood hazards at the Corrective Action Unit 407 from a 25$\mathrm{yr}, 6 \mathrm{-hr}$ storm. The site location is near the northeast corner of the intersection of Main Road and Browne's Lake Road. Approximately, $360 \mathrm{ft}$ north of the facility lies an existing 20 - $\mathrm{ft}$ wide channel, which passes under Main Road through two 3- $\mathrm{ft}$ culverts. Accumulated runoff from the contributing 1.2 $\mathrm{mi}^{2}$ watershed is directed away from the facility through ditches that run along Main and Browne's Lake Roads to the south and the 20 - $\mathrm{ft}$ channel to the north.

Discharges were determined using the HEC-1 rainfall-runoff model. The predicted discharge was then used to evaluate the v-ditches on either side of the Main Road, the two 3-ft culverts under Main Road, and the $20-\mathrm{ft}$ channel north of the facility.

\subsection{CONCLUSIONS}

Expected flood flows from a $25-\mathrm{yr}, 6-\mathrm{hr}$ storm are not expected to impact the facility. Runoff from $\mathrm{RC} 2$ (see Attachment 1) flows to the v-ditch west of main road (NW V-Ditch) where it is adequately conveyed to the two 3 -ft culverts north of the facility. The combined peak flow from $\mathrm{RC} 1$ and $\mathrm{RC} 2$ was $28 \mathrm{cfs}$. This flow was simulated in the $20-\mathrm{ft}$ channel north of the facility (W-E Channel) with approximately 2-ft of freeboard. The $20-\mathrm{ft}$ channel flows under Main Road via two existing 3-ft corrugated metal pipe culverts. These culverts will convey the flood flow with a headwater elevation approximately $2 \mathrm{ft}$ below road elevation under unsubmerged flow conditions.

\begin{tabular}{|c|c|c|c|c|c|}
\hline \multicolumn{6}{|c|}{ Record of Revisions } \\
\hline Revision No. & Reason for Revision & Date & Prepared & Checked & Approval \\
\hline 0 & Initial issue & $3 / 27 / 00$ & Enivor & ifforyeer & HSSBersmpen \\
\hline & & & & & \\
\hline & & & & & \\
\hline
\end{tabular}


ANALYSIS / CALCULATION (A/C) SHEET

\section{Project: \\ Subject: \\ Hydrologic/Hydraulic Analysis}

CAU 407 - Roller Coaster Radsafe Area, Tonopah Test Range

Date $3 / 27 / 00$

Section
Analysis/Calculation No:

$\mathrm{A} / \mathrm{C}-00022 . \mathrm{A} 54-\mathrm{C}-146$

1.0 INTRODUCTION

\section{Table of Contents}

$\underline{\text { Page Number }}$

2.0 CONCLUSIONS

TABLE OF CONTENTS. 2

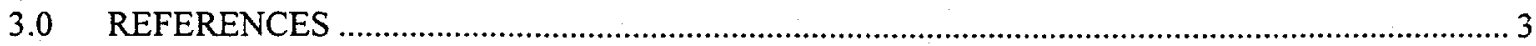

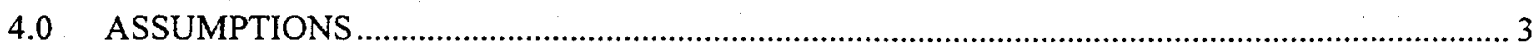

5.0 CALCULATION INPUT

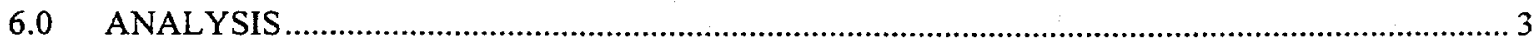

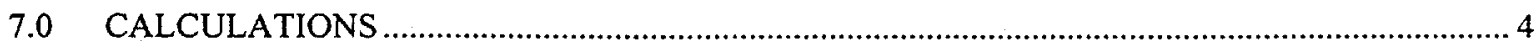

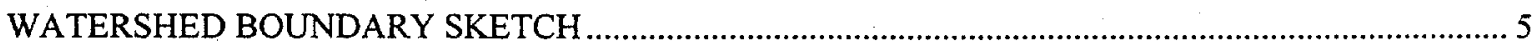

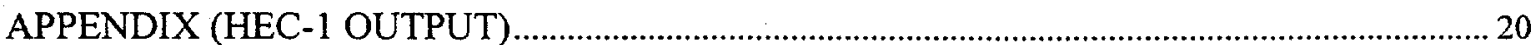




\section{ANALYSIS / CALCULATION (A/C) SHEET}

\begin{tabular}{|c|c|}
\hline $\begin{array}{l}\text { Project: } \\
\text { CAU } 407 \text { - Roller Coaster Radsafe Area, Tonopah Test Range }\end{array}$ & $\begin{array}{l}\text { Analysis/Calculation No.: } \\
\qquad A V-00022 . A 54-C-146\end{array}$ \\
\hline \multicolumn{2}{|l|}{$\begin{array}{l}\text { Subject: } \\
\text { Hydrologic/Hydraulic Analysis }\end{array}$} \\
\hline Date $3 / 27 / 00$ & Prepared by: $\operatorname{ImD}$ \\
\hline
\end{tabular}

\subsection{REFERENCES}

1. Clark County Regional Flood Control District (CCRFCD) Hydrologic Criteria and Drainage Design Manual, 1999 Edition.

2. Miller, J.F., R.H. Frederick and R.J. Tracy, 1973. Precipitation-frequency atlas of the Western United States, Vol. VII-Nevada, National Oceanic and Atmospheric Administration, Silver Spring, MD.

3. Soil Conservation Service (SCS). SCS National Engineering Handbook, Section 4, Hydrology. U.S. Department of Agriculture, paginated by section, March 1985.

\subsection{ASSUMPTIONS}

1. The time distribution of the $25-\mathrm{yr}, 6-\mathrm{hr}$ design precipitation depth (1.3 in.) was based on a technique described in Miller et al. (1973).

2. Runoff was estimated using the SCS curve number and Unit Hydrograph methods (SCS, 1985). The curve number used for this analysis was conservatively estimated at 75 which corresponds to a value describing hydrologic soil group B (medium runoff potential) of poor to fair vegetative ground cover ( $<70 \%$ ground cover).

3. Basin slopes were taken as representative averages throughout each subbasin.

4. Average cross-sections of the v-ditch (NW V-Ditch) northwest of the facility and the 20-ft channel (W-E Channel) just north of the facility were based on a digitized surface created from survey information.

\subsection{CALCULATION INPUT}

1. Basin Area

2. Basin lag time

4. Curve Number

5. Storm precipitation depth and storm distribution

5. V-Ditch and channel station and elevation (average cross-sections)

\subsection{ANALYSIS}

The $1.2 \mathrm{mi}^{2}$ watershed was divided into two subbasins, $\mathrm{RC} 1$ and $\mathrm{RC} 2$, to best represent surface drainage characteristics of the study area, see Attachment 1. Runoff was estimated using the HEC-1 rainfall-runoff model. Runoff from RC2 was simulated in NW V-Ditch (ditch northwest of the facility), which drains into the two 3-ft culverts under Main Road. Total flow (28 cfs) from RC1 and RC2 was then simulated in W-E Channel (20-ft channel draining from west to east about 360 - $\mathrm{ft}$ north of the facility. From the channel, the flood flow was simulated through the two $3-\mathrm{ft}$ culverts. Details of all simulations, including model input is contained in Section 7. "Calculations." 


\section{ANALYSIS / CALCULATION (A/C) SHEET}

\begin{tabular}{|l|r|}
\hline Project: & Analysis/Calculation No.: \\
CAU 407 - Roller Coaster Radsafe Area, Tonopah Test Range & A/C - 00022.A54-C-146
\end{tabular}

Subject:

Hydrologic/Hydraulic Analysis

\begin{tabular}{|l|l|}
\hline Date $3 / 27 / 00$ & Prepared by: IMD \\
\hline
\end{tabular} Checked by: Uy

Note: The HEC-1 model was run in English units, while all FlowMaster $($ and CulvertMaster $\AA$ simulations were performed using SI units. SI units were used because the digitized surface model used to obtain channel data was in metric units.

\subsection{CALCULATIONS}

Calculation details are included in the following pages. 


\section{RUNOFF CURVE NUMBERS \\ (SEMIARID RANGELANDS ${ }^{1}$ )}

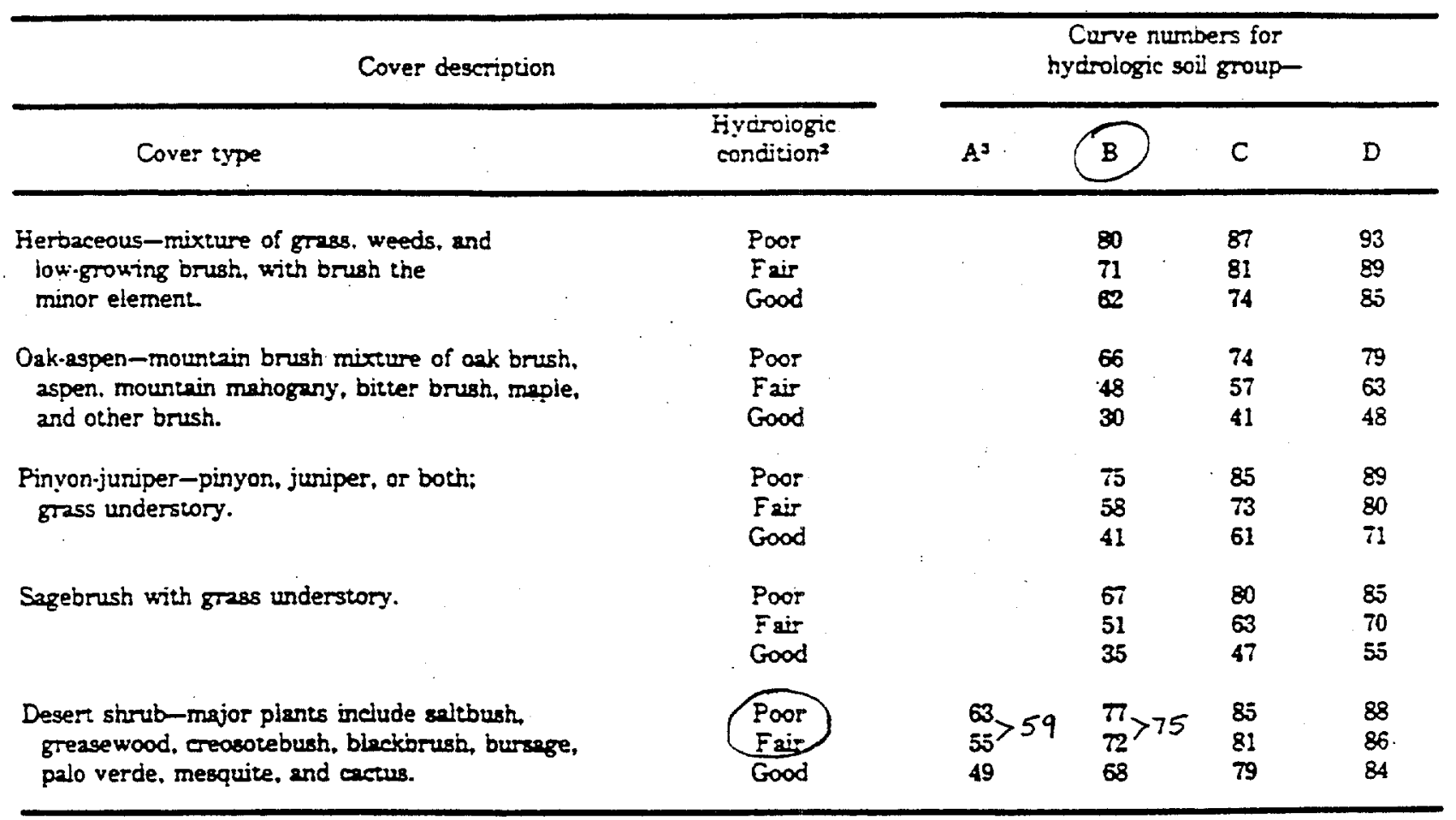

'Average runaf condition, and $I_{a}=0.25$.

2 '

fuir: 30 to 70 a ground cover.

Gixx?: > 70\% ground cover.

Purve numbers for group A huve been developed onjy fur deser shrub.

WRC ENGINEERING
REFERENCE:

SCS TR-55, USDA, June 1986. en-0005 (0089) Bechtel Hexada

Analysis Calc. \#: $A(C-00022 . A 54-C-146$

Prepared By: JinD

Checked By:

Rev.\#: 0 Page 6 of 25

\begin{tabular}{|l|l|}
\hline Revision & Date \\
\hline & \\
\hline & \\
\hline & \\
\hline &
\end{tabular}


Sheet 7 of 25

Bechtel Nevada

ANALYSIS / CALCULATION (ATC) SHEET

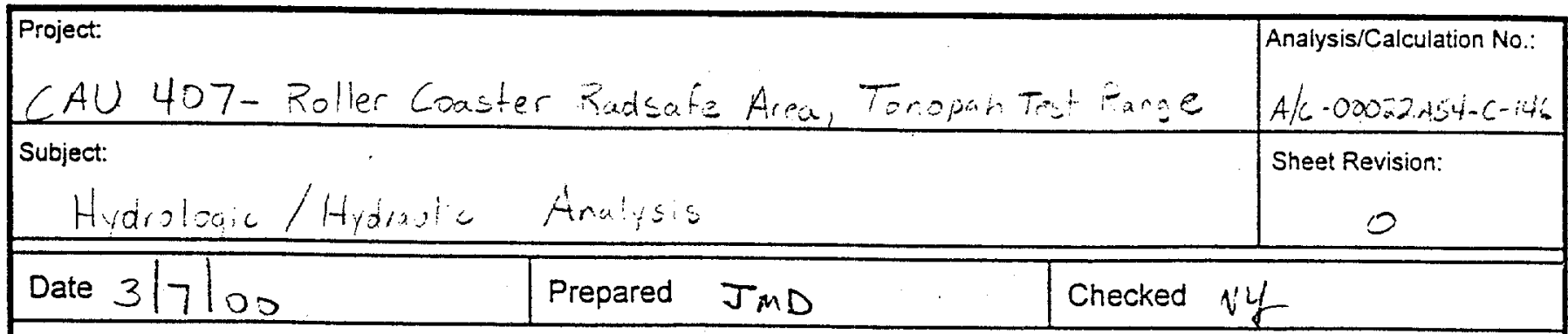

Site Location: $37^{\circ} 43^{\prime} \mathrm{N}$

$$
116^{\circ} 44^{\circ} E
$$

* Basin areas were determined using "PLA NIX", Tamara Digital Planimeter with USEs 7.5 min. Topographic Quadrangles * 1":2000"

Subbasin

RC I

RC 2

Scaled

$\frac{\begin{array}{c}\text { Area } \\ \left(\mathrm{in}^{2}\right)\end{array}}{5.5} \quad \frac{\left[\mathrm{Ft}^{2}\right]}{2.2 \times 10^{7}} \quad \frac{\left[\mathrm{mi}^{2}\right]}{.79}$

2.9

$1.16 \times 10^{7}$

.42

* A range of runoff curve numbers will be evaluated assuming Poor/Fair conditions, Values for Hydrology, Soil groups $A, B, C$ (see attached Table 602 from CCRECD, 1999)

* Basin Lag times are calculated from Ens. (601) and (602) (CCRFCD, 1999) for areas less than $1 \mathrm{mi}^{2}$.

where:

$$
\begin{aligned}
& T_{\text {lag }}=0.6 t_{c} \quad(612) \\
& t_{c}=t_{i}+t_{t} \quad(601) \\
& t_{i}=\frac{1.8(1.1-K) L_{0}^{1 / 2}}{\sqrt[3]{S} \quad(602)} \\
& K=0.0132(\mathrm{CN})-.39 \quad 003) \\
& t_{t}=\frac{L}{V_{L}}\left(\text { from } f_{j} .602 .\right. \text { CERFCO,1909) }
\end{aligned}
$$

BN-0405 (11/98) 


\section{TRAVEL TIME VELOCITY}

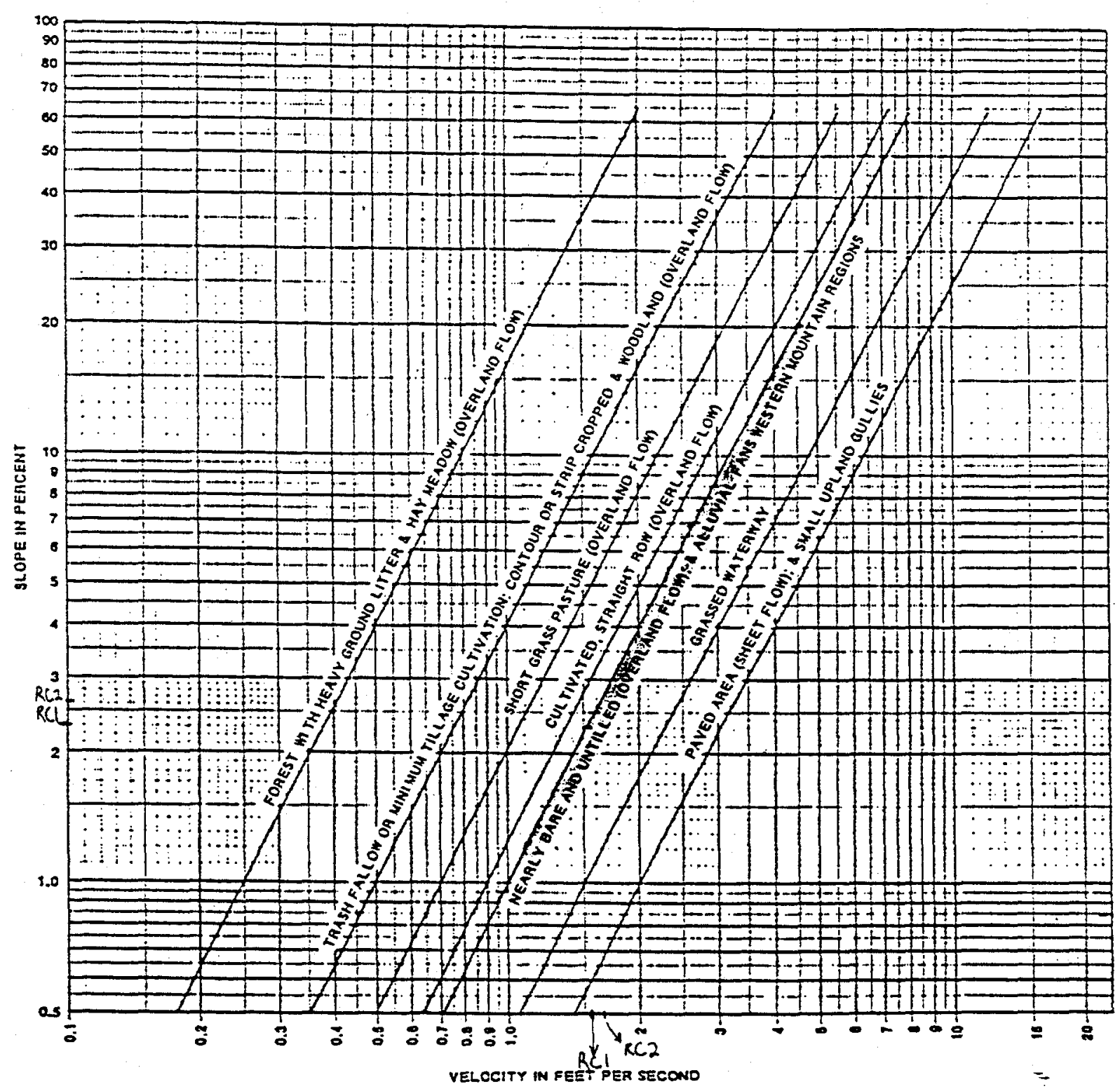

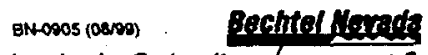

Analysis Calc. \#:AlC-00022. $454-C-146$ Prepared By: JMD

Checked By: Uy

Rev.\#: 0 Page_\& of 25

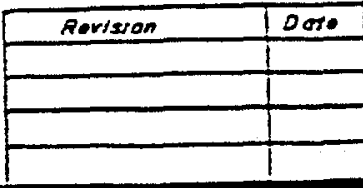

FIGURE 602 
Lag Time (<1 sq. mi.)

\begin{tabular}{|c|c|c|c|c|c|c|c|c|c|c|c|}
\hline $\mathrm{CN}=59$ & & & & & FAA & hod (CC) & RFCD, 1999 & & & & \\
\hline Sub-Basin & Data & & nitial/Over & nd Flow & & & Travel Tim & $\left(t_{t}\right)$ & & $\begin{array}{c}\text { Time of } \\
\text { Concentration }\end{array}$ & $\begin{array}{l}\text { Lag } \\
\text { Time } \\
\end{array}$ \\
\hline Designation & $\begin{array}{l}\text { Area } \\
\left(\mathrm{mi}^{2}\right)\end{array}$ & ${ }^{2} K$ & $\begin{array}{l}{ }^{3} \text { Length } \\
\text { (ft) }\end{array}$ & $\begin{array}{l}\text { Slope } \\
\%\end{array}$ & $\begin{array}{c}t_{i} \\
(\min )\end{array}$ & $\begin{array}{l}\text { Length } \\
\text { (ft) }\end{array}$ & $\begin{array}{c}\text { Channel } \\
\text { Slope } \\
\%\end{array}$ & $\underset{(\mathrm{ft} / \mathrm{sec})}{V}$ & $\begin{array}{c}t_{4} \\
(\min )\end{array}$ & $(\min )$ & $\underset{(h r)}{L}$ \\
\hline $\mathrm{RC1}$ & 0.79 & 0.39 & 500 & 5.0 & 16.7 & 7000 & 2.3 & 1.6 & 72.9 & 89.7 & 0.90 \\
\hline $\mathrm{RC2}$ & 0.42 & 0.39 & 500 & 5.6 & 16.1 & 8500 & 2.6 & 1.7 & 83.3 & 99.4 & 0.99 \\
\hline 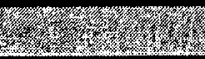 & res & Syia & 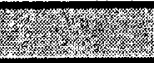 & 28 & 2 & 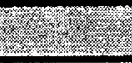 & 8 & & & (2) & 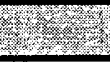 \\
\hline $\mathrm{CN}=67$ & & & & & FAA & hod (CC & RFCD, 1999 & & & & \\
\hline Sub-Basin & Data & & nitial/Over & nd Flow & & & Travel Tim & $\left(t_{t}\right)$ & & $\begin{array}{c}\text { Time of } \\
\text { Concentration }\end{array}$ & $\begin{array}{l}\text { Lag } \\
\text { Time }\end{array}$ \\
\hline Designation & $\begin{array}{l}\text { Area } \\
\left(\mathrm{mi}^{2}\right)\end{array}$ & ${ }^{2} \mathrm{~K}$ & $\begin{array}{l}{ }^{3} \text { Length } \\
\text { (ft) }\end{array}$ & $\begin{array}{c}\text { Slope } \\
\%\end{array}$ & $\begin{array}{c}\mathbf{t}_{\mathbf{i}} \\
(\min )\end{array}$ & $\begin{array}{l}\text { Length } \\
\text { (ft) }\end{array}$ & $\begin{array}{c}\text { Channel } \\
\text { Slope } \\
\%\end{array}$ & $\begin{array}{c}V \\
(\mathrm{ft} / \mathrm{sec})\end{array}$ & $\begin{array}{c}\mathbf{t}_{\mathrm{t}} \\
(\mathrm{min})\end{array}$ & $(\min )$ & $\begin{array}{l}\mathrm{L} \\
(\mathrm{hr})\end{array}$ \\
\hline RC1 & 0.79 & 0.49 & 500 & 5.0 & 14.3 & 7000 & 2.3 & 1.6 & 72.9 & 87.2 & 0.87 \\
\hline $\mathrm{RC2}$ & 0.42 & 0.49 & 500 & 5.6 & 13.7 & 8500 & 2.6 & 1.7 & 83.3 & 97.0 & 0.97 \\
\hline 谁- & & & & & & & 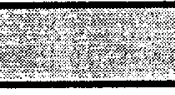 & & & 2.5. & (3) \\
\hline$C N=75$ & & & & & FAA $A$ & hod $(\mathrm{CC}$ & $\mathrm{RFCD}, 1999$ & & & & \\
\hline Sub-Basin & Data & & Initial/Over & nd Flow & & & Travel Tim & $\left(t_{t}\right)$ & & $\begin{array}{c}\text { Time of } \\
\text { Concentration }\end{array}$ & $\begin{array}{l}\text { Lag } \\
\text { Time }\end{array}$ \\
\hline Designation & $\begin{array}{l}\text { Area } \\
\left(\mathrm{mi}^{2}\right)\end{array}$ & ${ }^{2} K$ & $\begin{array}{l}{ }^{3} \text { Length } \\
\text { (ft) }\end{array}$ & $\begin{array}{l}\text { Slope } \\
\%\end{array}$ & $\begin{array}{c}\mathbf{t}_{1} \\
(\mathrm{~min})\end{array}$ & $\begin{array}{l}\text { Length } \\
\text { (ft) }\end{array}$ & $\begin{array}{c}\text { Channel } \\
\text { Slope } \\
\% \\
\end{array}$ & $\begin{array}{c}V \\
(\mathrm{ft} / \mathrm{sec})\end{array}$ & $\begin{array}{c}\mathbf{t}_{\mathrm{t}} \\
(\min )\end{array}$ & $(\min )$ & $\underset{(h r)}{\mathrm{L}}$ \\
\hline $\mathrm{RC} 1$ & 0.79 & 0.60 & 500 & 5.0 & 11.8 & 7000 & 2.3 & 1.6 & 72.9 & 84.7 & 0.85 \\
\hline $\mathrm{RC2}$ & 0.42 & 0.60 & 500 & 5.6 & 11.3 & 8500 & 2.6 & 1.7 & 83.3 & 94.6 & 0.95 \\
\hline
\end{tabular}

${ }^{1}$ Originally developed by the Federal Aviation Administration

${ }^{2}$ Flow resistance coefficient from Equation 603, CCRFCD 1999

${ }^{3}$ Maximum allowable flow length is $500 \mathrm{ft}$., CCRFCD 1999 
Derivation of 25-yr 6-hr storm data from NOAA Atlas II for Nevada

\begin{tabular}{|c|c|c|}
\hline & Table 12 & Depth \\
\hline $\mathbf{x} 1$ & 2-yr 6-hr depth & 0.7 \\
\hline$\times 2$ & 2-yr 24-hr depth & 1 \\
\hline$\times 3$ & 100-yr 6-hr depth & 1.6 \\
\hline$\times 4$ & 100-yr 24-hr depth & 2.2 \\
\hline Y2 & & 0.4 \\
\hline Y100 & & 1.2 \\
\hline $25 y r 6 h r$ & & 1.3 \\
\hline $25-y r 1 . h r$ & Form 3, CCRFCD & 0.85 \\
\hline \multicolumn{3}{|c|}{ 25-yr 2-hr and 3-hr values } \\
\hline $2-h r$ & & 0.98 \\
\hline 3-hr & 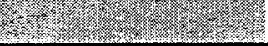 & 1.09 \\
\hline \multicolumn{3}{|c|}{ Table 13} \\
\hline $5-\min$ & & 0.25 \\
\hline $10-\min$ & & 0.38 \\
\hline $15-\min$ & & 0.48 \\
\hline 30-min & & 0.67 \\
\hline
\end{tabular}

*Precipitation adjustment ratios based on CCRFCD, 1999 
PRECIPITATION DEPTH VERSUS RETURN PERIOD

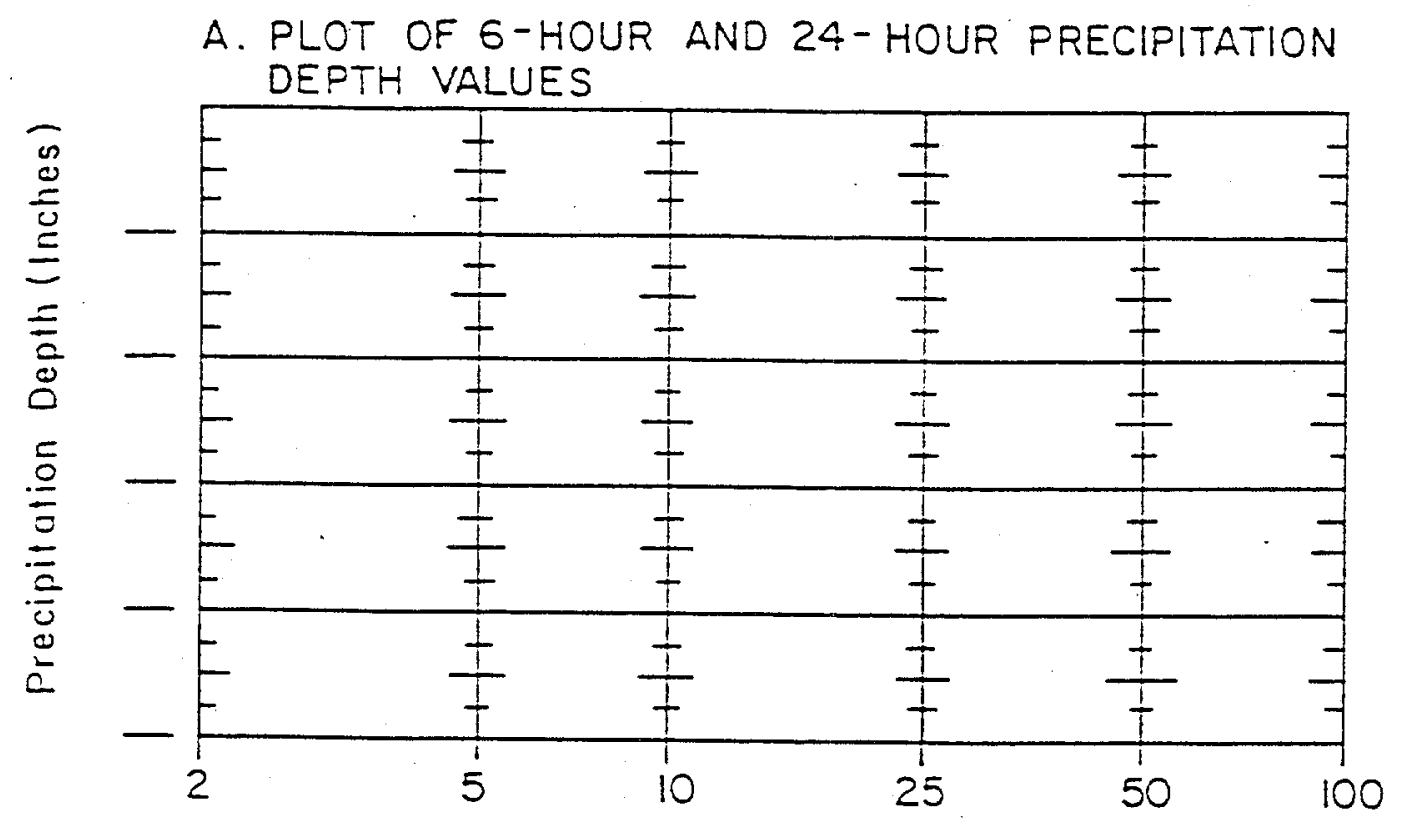

Return Period in Years, Partial-Duration Series

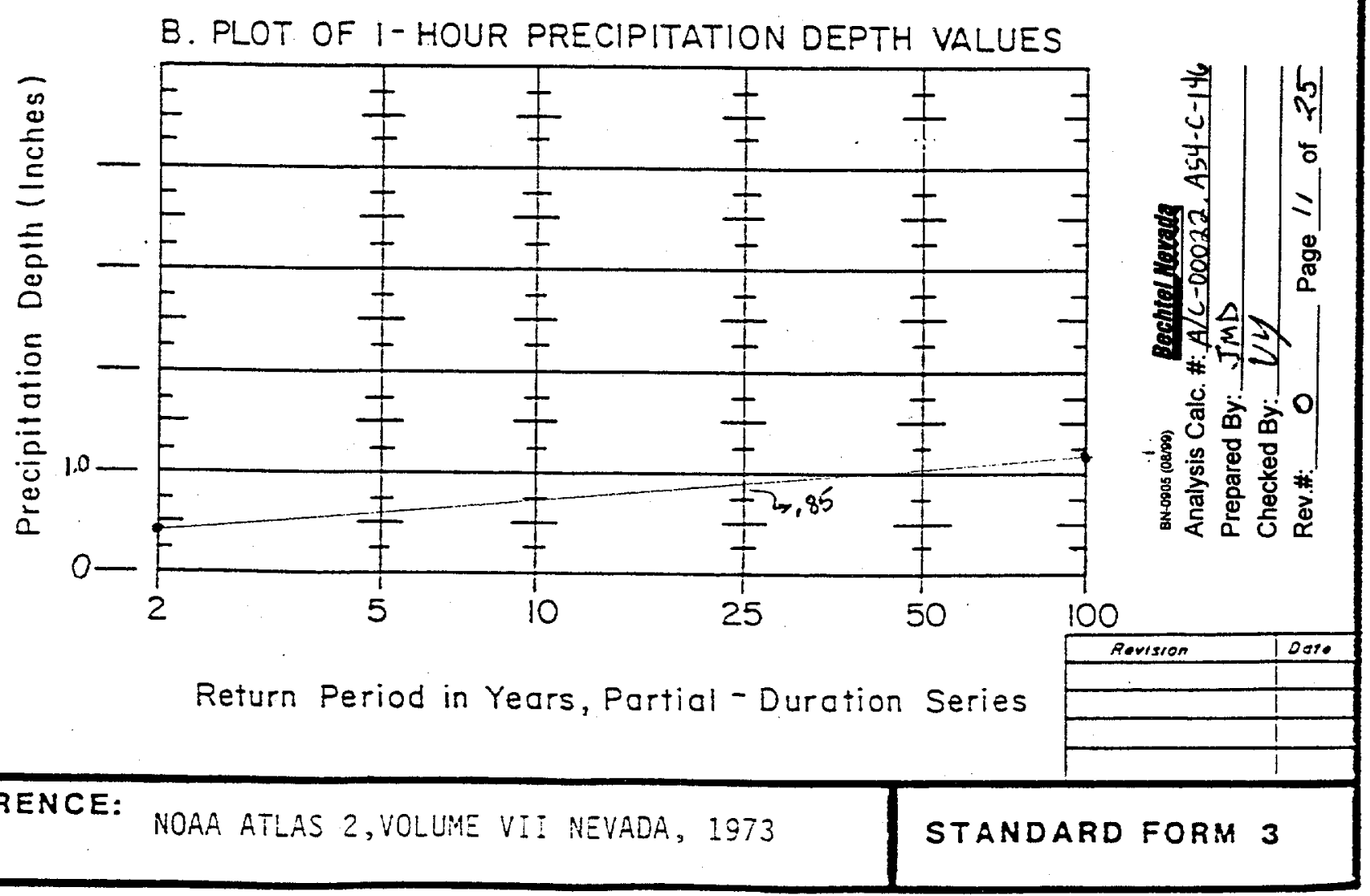




\section{BN-0905 (0B/99) Becntel nevaga}

HEC-1 Results

\begin{tabular}{lccc} 
& \multicolumn{3}{c}{ English } \\
Curve Number & 59 & 67 & 75 \\
Total Flow, cfs & 0 & 4 & 28 \\
RC2 Flow, cfs & 0 & 1 & 10 \\
& & & \\
& & Metric & \\
Curve Number & 59 & 67 & 75 \\
Total Flow, cms & 0.0 & 0.1 & 0.8 \\
RC2 Flow, cms & 0.0 & 0.0 & 0.3
\end{tabular}

75

28

10

75

0.3
Analysis Calc. \#: AK-00022,As4-C-146 Prepared By: Jim D

Checked By: $\frac{V y}{0 \text { Page } 12 \text { of } 25}$ 


\section{Ditches West of Facility}

- NW (west side of Main Rd.)

\begin{tabular}{lccc}
\multicolumn{1}{c}{ Station } & $\begin{array}{c}\text { Left Bank } \\
(\mathrm{H}: \mathrm{V})\end{array}$ & $\begin{array}{c}\text { Right Bank } \\
(\mathrm{H}: \mathrm{V})\end{array}$ & $\begin{array}{c}\text { Minimum } \mathrm{Ht} . \\
(\mathrm{m})\end{array}$ \\
$0+00$ & 7.9 & 19.3 & 0.2 \\
$0+75$ & 11.9 & 22.5 & 0.09 \\
$1+50$ & 7.3 & 11.3 & 0.23 \\
$2+25$ & 7.7 & 6.2 & 0.95 \\
\cline { 2 - 4 } Average & 8.7 & 14.8 & 0.37
\end{tabular}

NE (east side of Main Rd.)

\begin{tabular}{lccc} 
Station & $\begin{array}{c}\text { Left Bank } \\
(\mathrm{H}: \mathrm{V})\end{array}$ & $\begin{array}{c}\text { Right Bank } \\
(\mathrm{H}: \mathrm{V})\end{array}$ & $\begin{array}{c}\text { Minimum } \mathrm{Ht} . \\
(\mathrm{m})\end{array}$ \\
$0+00$ & 18.9 & 7.2 & 0.3 \\
$0+75$ & 64.6 & 7.2 & 0.05 \\
$1+50$ & 7.2 & 7.1 & 0.44 \\
$2+25$ & 7.6 & 6.5 & 0.53 \\
\cline { 2 - 4 } Average & 24.6 & 7.0 & 0.33
\end{tabular}

*Arbitrary starting stations and elevations
Bnosos (0889) Bechtel Nerada

Analysis Calc. \#: AlC-00022, A54-C-

Prepared By: JMD

Checked By: Uy

Rev.\#:

Page 13 of 25

\begin{tabular}{lcccc}
\multicolumn{3}{c}{} & \multicolumn{3}{c}{ NW V-Ditch } \\
\cline { 3 - 5 } & Left & Bottom & Right \\
\cline { 2 - 4 } Station $^{*}$ & 100 & 103.20 & 108.65 \\
Elevation* $^{*}$ & 100 & 99.63 & 100.00
\end{tabular}

\begin{tabular}{lccc}
\multicolumn{3}{c}{} & \multicolumn{3}{c}{ NE V-Ditch } \\
\cline { 3 - 5 } Station* $^{*}$ & Left & Bottom & Right \\
\cline { 2 - 4 } Elevation $^{*}$ & 100 & 108.11 & 110.42 \\
& 100 & 99.67 & 100.00
\end{tabular}


NW 75

Worksheet for Irregular Channel an-0805 (08/9)

\section{Bechtel Mevada}

Analysis Calc. \#: $A k-00022.45 y-C-146$

Prepared By:

JiMD

Checked By: Uy

Rev.\#: Page 14 of 25

\begin{tabular}{ll}
\hline Project Description & \\
\hline Project File & g:Idgnl00022a54lhydrologlnwvditch.fm2 \\
Worksheet & NW V-Ditch, CN 75 \\
Flow Element & Irregular Channel \\
Method & Manning's Formula \\
Solve For & Water Elevation \\
\hline
\end{tabular}

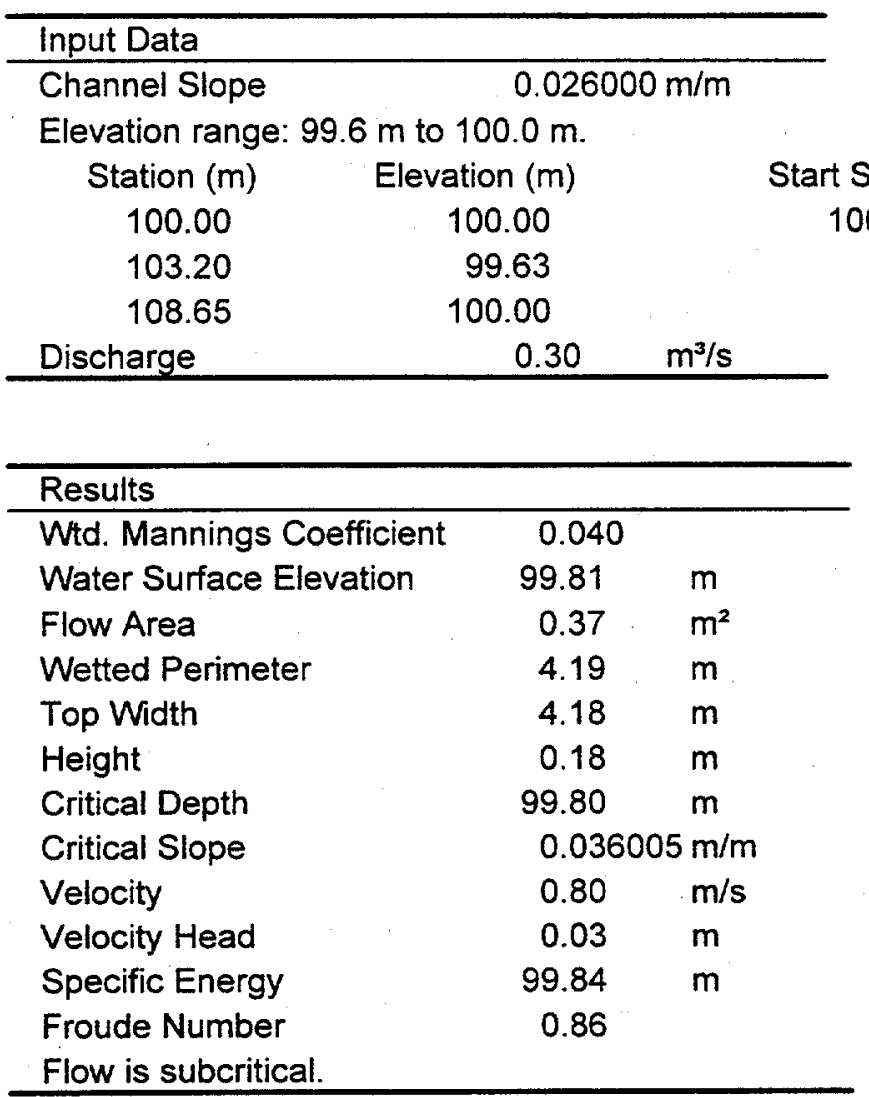


NW, CN 75

Cross Section for Irregular Channel
BNo905 (0809) Bechtel Nevada

Analysis Calc. \#:Alc-000232 A54-C-14C

Prepared By: JMD

Checked By: $\vee y$

Rev. Page 15 of 25

\begin{tabular}{ll}
\hline Project Description & \\
\hline Project File & g:Idgnl00022a54lhydrologlnwvditch.fm2 \\
Worksheet & NW V-Ditch, CN 75 \\
Flow Element & Irregular Channel \\
Method & Manning's Formula \\
Solve For & Water Elevation \\
\hline
\end{tabular}

\begin{tabular}{ll}
\hline Section Data & \\
\hline Wtd. Mannings Coefficient & 0.040 \\
Channel Slope & $0.026000 \mathrm{~m} / \mathrm{m}$ \\
Water Surface Elevation & $99.81 \quad \mathrm{~m}$ \\
Discharge & $0.30 \quad \mathrm{~m}^{3} / \mathrm{s}$ \\
\hline
\end{tabular}

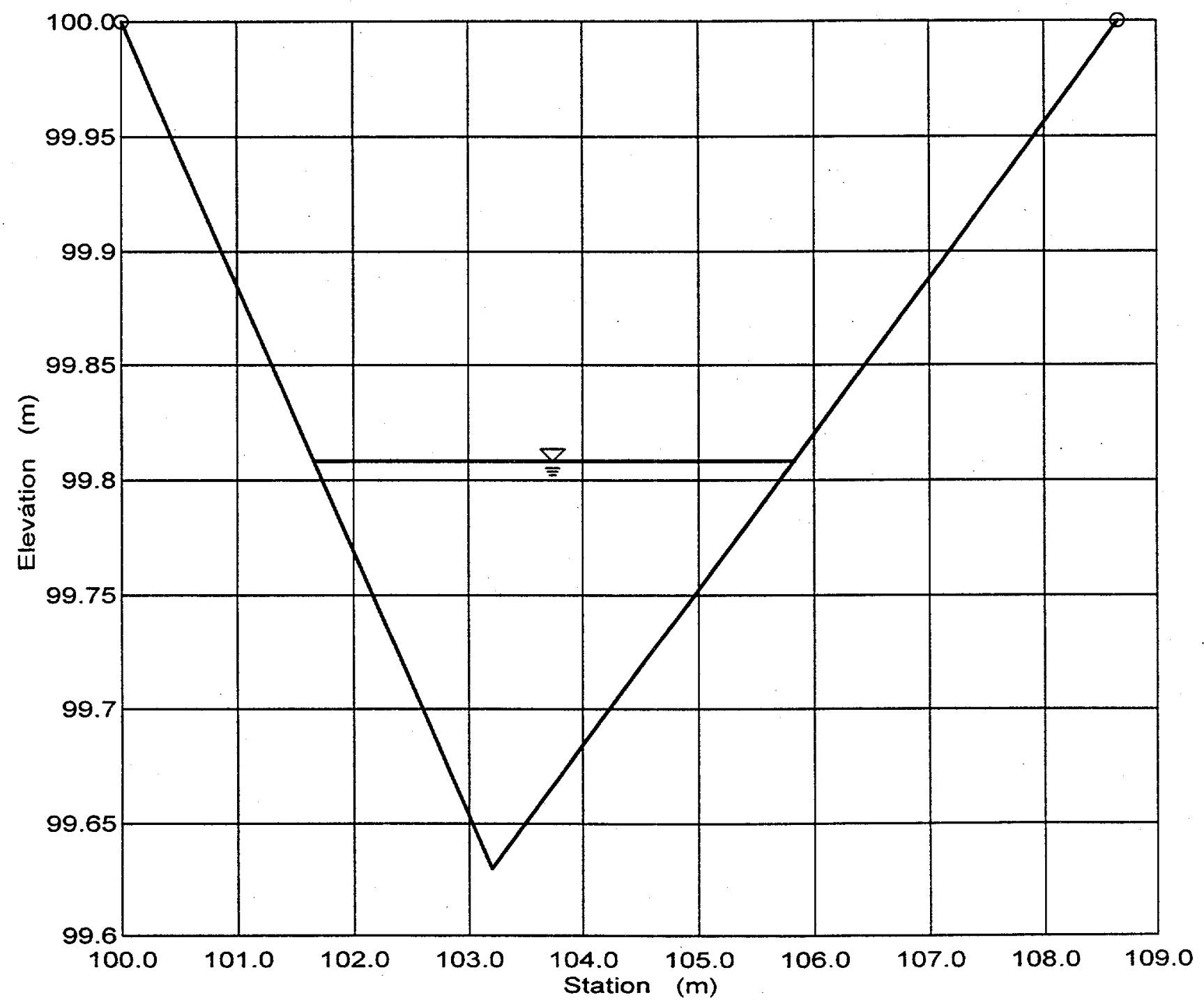




\begin{tabular}{|c|c|c|c|c|c|c|c|c|c|}
\hline \multicolumn{5}{|c|}{ Upstream of Culvert } & & \multicolumn{4}{|c|}{ Rev.\#: $\quad 0$ Page 16 of 25} \\
\hline & & SLOPE $=$. & $.026 \mathrm{~m} / \mathrm{m}$ & & & & & & \\
\hline Station & $\begin{array}{l}\text { Left Bank } \\
(\mathrm{H}: \mathrm{V})\end{array}$ & $\begin{array}{c}\text { Bottom } \\
\text { Width (m) }\end{array}$ & $\begin{array}{l}\text { Right Bank } \\
(H: V)\end{array}$ & $\begin{array}{l}\text { Height. } \\
\text { (m) }\end{array}$ & & & & & \\
\hline $0+00$ & - & & - & - & & & & & \\
\hline $0+10$ & 14 & 4.3 & 8.4 & 0.89 & & & & & \\
\hline $0+20$ & 12.7 & 4.7 & 9.5 & 0.77 & & & & & \\
\hline $0+30$ & 9.7 & 5.2 & 3.2 & 0.74 & & & & & \\
\hline $0+40$ & 9.7 & 6.9 & 7.3 & 0.69 & & & & & \\
\hline $0+50$ & 9.7 & 7.4 & 5.1 & 0.67 & & & & & \\
\hline $0+60$ & 9.7 & 7.4 & 5.1 & 0.66 & & Top Left & Bottom Left & Bottom Right & Top Right \\
\hline $0+64.86$ & - & - & - & - & Station $^{*}$ & 100 & 91.96 & 85.97 & 81.24 \\
\hline Average & 10.9 & 6.0 & 6.4 & 0.74 & Elevation* & 100 & 99.26 & 99.26 & 100 \\
\hline & Dowr & $\begin{array}{c}\text { stream of C } \\
\text { SLOPE }=\end{array}$ & $\begin{array}{l}\text { ulvert } \\
.026 \mathrm{~m} / \mathrm{m}\end{array}$ & & & & & & \\
\hline Station & $\begin{array}{c}\text { Left Bank } \\
(H: V)\end{array}$ & $\begin{array}{l}\text { Bottom } \\
\text { Width (m) }\end{array}$ & $\begin{array}{l}\text { Right Bank } \\
(H: V)\end{array}$ & $\begin{array}{l}\text { Height. } \\
\text { (m) }\end{array}$ & & & & & \\
\hline $0+00$ & 2.4 & 8.3 & 7.8 & 1.4 & & & & & \\
\hline $0+20$ & 1.8 & 21 & 3.1 & 1.5 & & & & & \\
\hline $0+40$ & 8.6 & 16.1 & 3.4 & 1.5 & & & & & \\
\hline $0+60$ & 9.9 & 6.6 & 3.1 & 1.5 & & & & & \\
\hline $0+80$ & 6.7 & 6.2 & 3.8 & 1.2 & & & & & \\
\hline $1+20$ & 5.4 & 7.6 & 3.1 & 0.9 & & & & & \\
\hline $1+40$ & & & & & & & & & \\
\hline $1+60$ & & Past Facility & & & & Top Left & Bottom Left & Bottom Right & Top Right \\
\hline $1+80$ & 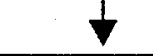 & & 7 & & Station* & 100 & 92.27 & 81.30 & 75.90 \\
\hline Average & 5.8 & 11.0 & 4.1 & 1.3 & Elevation* & 100 & 98.67 & 98.67 & 100 \\
\hline
\end{tabular}

*Arbitrary starting stations and elevations 
CN 75

Worksheet for Irregular Channel

\begin{tabular}{ll}
\hline Project Description & \\
\hline Project File & g:Idgnl00022a54lhydrologlw-echanl.fm2 \\
Worksheet & W-E Upstream Channel, CN 75 \\
Flow Element & Irregular Channel \\
Method & Manning's Formula \\
Solve For & Water Elevation \\
\hline
\end{tabular}

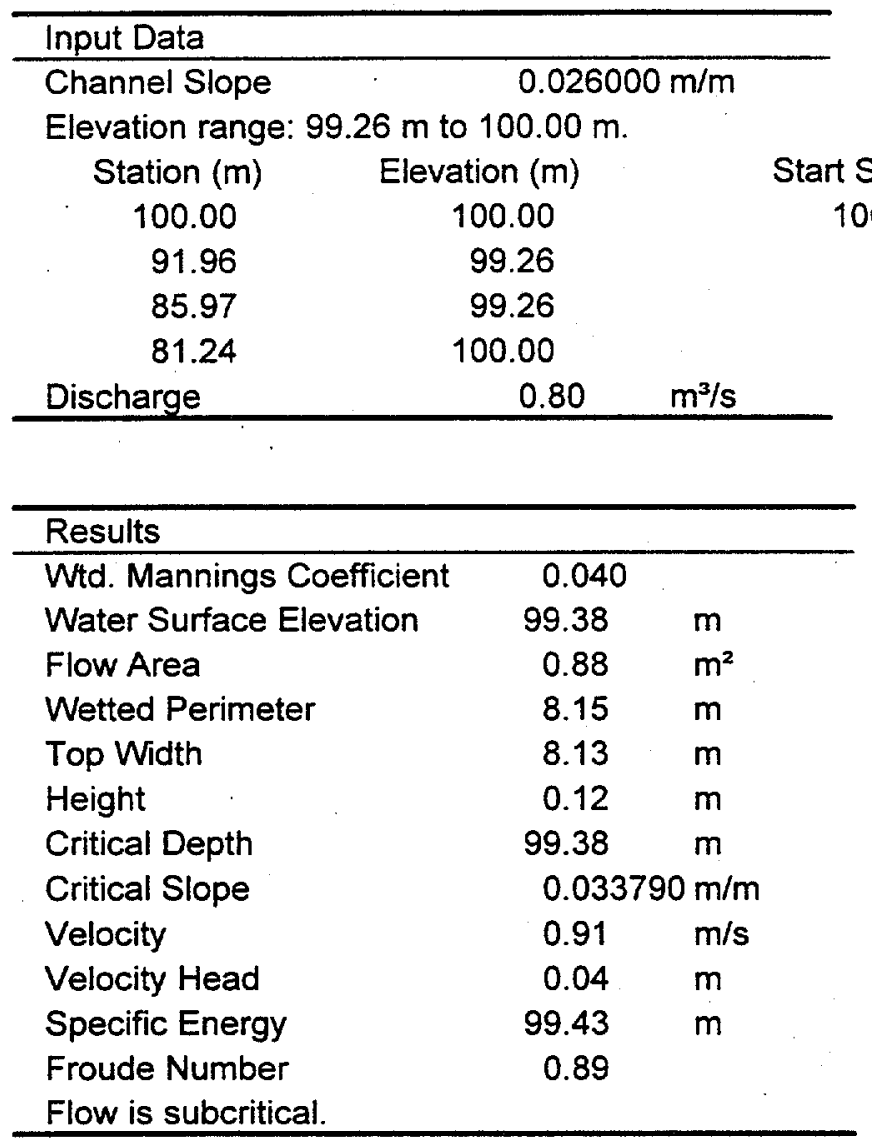


CN 75

Cross Section for Irregular Channel

Analysis Calc. \#: $A / C-\operatorname{coc} 22, A 54-c-146$

Prepared By: JinD

Checked By: $\backslash y$

Rev.\#: Page is of 25

\begin{tabular}{ll}
\hline Project Description & \\
\hline Project File & g:Idgnl00022a54lhydrologlw-echanl.fm2 \\
Worksheet & W-E Upstream Channel, CN 75 \\
Flow Element & Irregular Channel \\
Method & Manning's Formula \\
Solve For & Water Elevation \\
\hline
\end{tabular}

\begin{tabular}{ll}
\hline Section Data & \\
\hline Wtd. Mannings Coefficient & 0.040 \\
Channel Slope & $0.026000 \mathrm{~m} / \mathrm{m}$ \\
Water Surface Elevation & $99.38 \mathrm{~m}$ \\
Discharge & $0.80 \quad \mathrm{~m}^{3} / \mathrm{s}$ \\
\hline
\end{tabular}

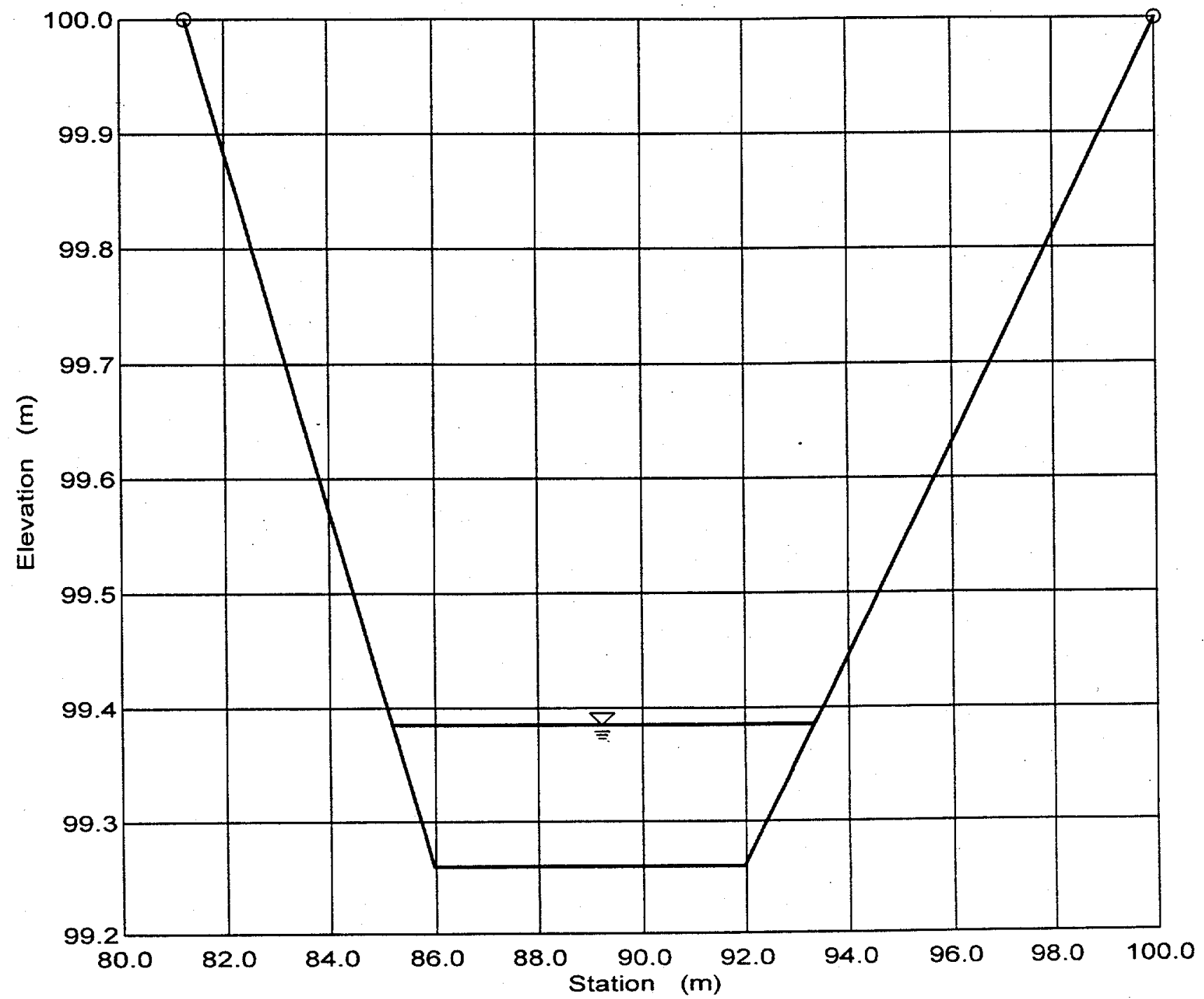




\section{Culvert Calculator Report \\ CN 75}

Analysis Calc. \#: $A / 6-00022, A 54 . \mathrm{C}$. Prepared By: Jin D Checked By: Uy

Rev.\#: Page 19 of 25

Solve For: Headwater Elevation

\begin{tabular}{|c|c|c|c|}
\hline Culvert Summary & & & . \\
\hline Allowable HW Elevation & $1,700.100 \mathrm{~m}$ & Headwater Depth/ Height & $0.68<36+$ \\
\hline Computed Headwater Elevation & $1,699.524 \mathrm{~m}$ & Discharge & $0.8000 \mathrm{~m}^{3} / \mathrm{s}$ \\
\hline Inlet Control HW Elev & $1,699.418 \mathrm{~m}$ & Tailwater Elevation & $1,699.200 \mathrm{~m}$ \\
\hline Outlet Control HW Elev & $1,699.524 \mathrm{~m}$ & Control Type & Entrance Control \\
\hline \multicolumn{4}{|l|}{ Grades } \\
\hline Upstream Invert & $1,698.900 \mathrm{~m}$ & Downstream Invert & $1,698.300 \mathrm{~m}$ \\
\hline Length & . $12.270 \mathrm{~m}$ & Constructed Slope & $0.048900 \mathrm{~m} / \mathrm{m}$ \\
\hline \multicolumn{4}{|l|}{ Hydraulic Profile } \\
\hline Profile & Composites1S2 & Depth, Downstream & $0.900 \mathrm{~m}$ \\
\hline Slope Type & Steep & Normal Depth & $0.260 \mathrm{~m}$ \\
\hline Flow Regime & N/A & Critical Depth & $0.365 \mathrm{~m}$ \\
\hline Velocity Downstream & $0.611 \mathrm{~m} / \mathrm{s}$ & Critical Slope & $0.013587 \mathrm{~m} / \mathrm{m}$ \\
\hline \multicolumn{4}{|l|}{ Section } \\
\hline Section Shape & Circular & Mannings Coefficient & 0.024 \\
\hline Section Material & CMP & Span & $0.914 \mathrm{~m}$ \\
\hline Section Size & $900 \mathrm{~mm}$ & Rise & $0.914 \mathrm{~m}$ \\
\hline Number Sections & 2 & & \\
\hline \multicolumn{4}{|l|}{ Outlet Control Properties } \\
\hline Outlet Control HW Elev & $1,699.524 \mathrm{~m}$ & Upstream Velocity Head & $0.136 \mathrm{~m}$ \\
\hline $\mathrm{Ke}$ & 0.90 & Entrance Loss & $0.123 \mathrm{~m}$ \\
\hline \multicolumn{4}{|l|}{ Inlet Control Properties } \\
\hline Inlet Control HW Elev & $1,699.418 \mathrm{~m}$ & Flow Control & Unsubmerged \\
\hline Inlet Type & Projecting & Area Full & $1.31 \mathrm{~m}^{2}$ \\
\hline K & 0.03400 & HDS 5 Chart & 2 \\
\hline $\mathbf{M}$ & 1.50000 & HDS 5 Scale & 3 \\
\hline C & 0.05530 & Equation Form & 1 \\
\hline$Y$ & 0.54000 & & \\
\hline
\end{tabular}




\section{Project:}

CAU 407 - Roller Coaster Radsafe Area, Tonopah Test Range

Subject:

Hydrologic/Hydraulic Analysis

Date $3 / 27 / 00$
Analysis/Calculation No::

AV - 00022.A54-C-146

Date $3 / 27 / 00$



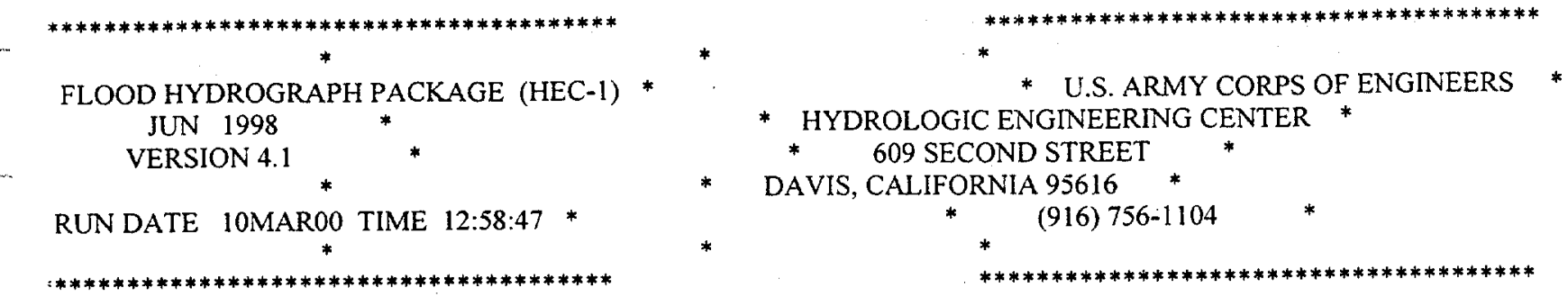

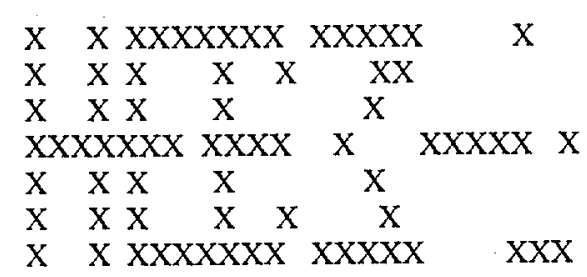

THIS PROGRAM REPLACES ALL PREVIOUS VERSIONS OF HEC-1 KNOWN AS HECI (JAN 73), HECIGS, HECIDB, AND HECIKW.

THE DEFINITIONS OF VARIABLES -RTIMP- AND -RTIOR- HAVE CHANGED FROM THOSE USED WITH THE 1973-STYLE INPUT TRUCTURE. ERSION

THE DEFINITION OF -AMSKK- ON RM-CARD WAS CHANGED WITH REVISIONS DATED 28 SEP 81. THIS IS THE FORTRAN77

NEW OPTIONS: DAMBREAK OUTFLOW SUBMERGENCE, SINGLE EVENT DAMAGE CALCULATION, DSS:WRITE STAGE ZEQUENCY,

DSS:READ TIME SERIES AT DESIRED CALCULATION INTERVAL LOSS RATE:GREEN AND AMPT INFILTRATION

KINEMATIC WAVE: NEW FINITE DIFFERENCE ALGORITHM

HEC-1 INPUT PAGE 1

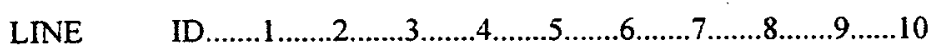

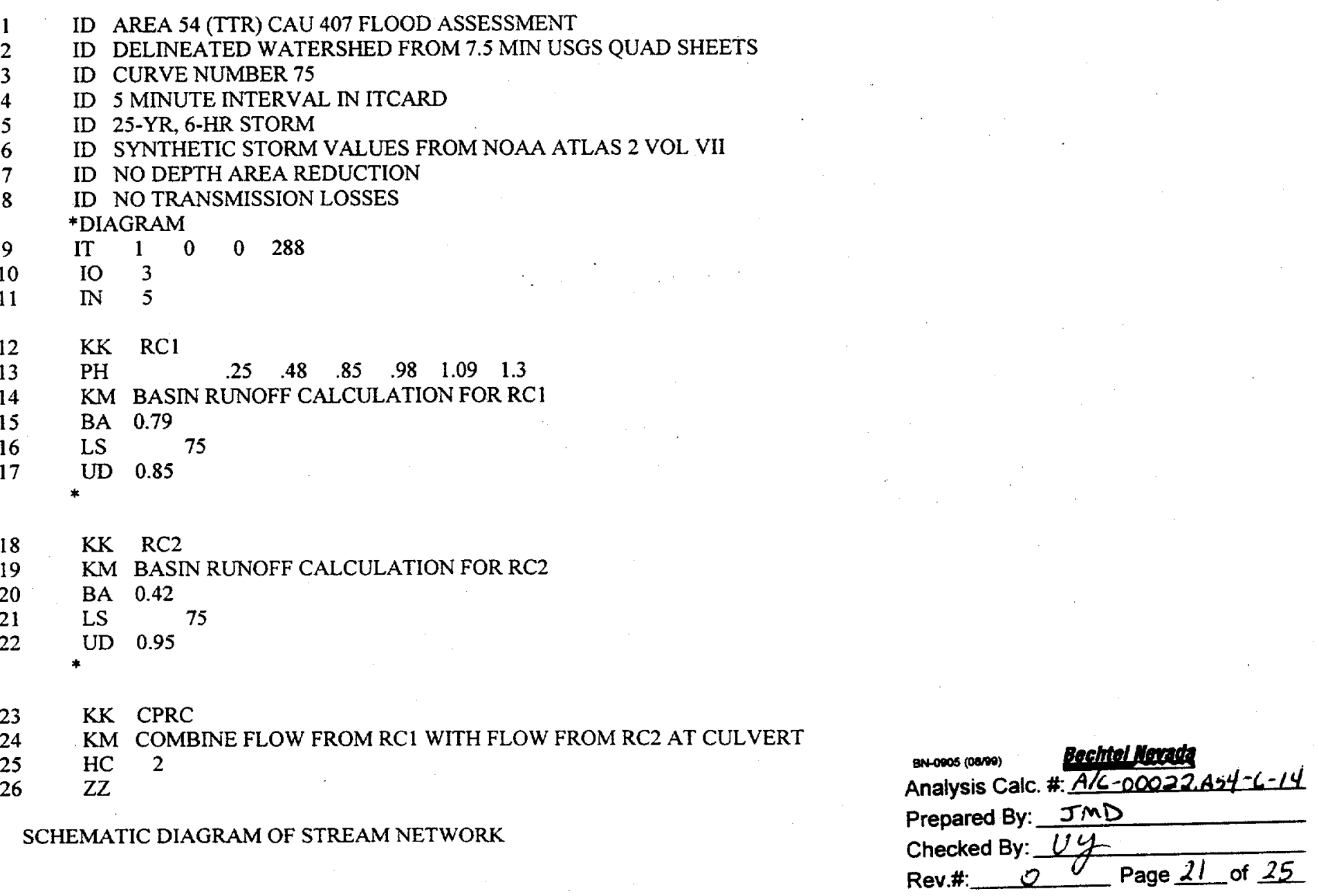


JPUT

INE (V) ROUTING (-->) DIVERSION OR PUMP FLOW

VO. (.) CONNECTOR (<---) RETURN OF DIVERTED OR PUMPED FLOW

$12 \quad \mathrm{RCl}$

$18 . \mathrm{RC} 2$

23

CPRC
BN-0005 (08/99)

Bechtel Nevada

Analysis Calc. \#:AL-000?2 $454-c-146$ Prepared By: Jind

Checked By: $1 / y$

Rev.\#: Page 22 of 25

:**) RUNOFF ALSO COMPUTED AT THIS LOCATION

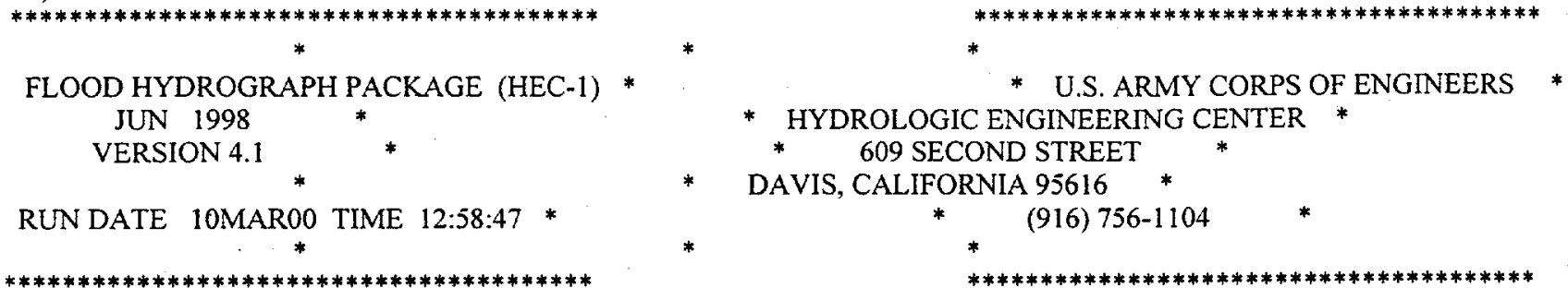

AREA 54 (TTR) CAU 407 FLOOD ASSESSMENT

DELINEATED WATERSHED FROM 7.5 MIN USGS QUAD SHEETS

CURVE NUMBER 75

5 MINUTE INTERVAL IN ITCARD

25-YR, 6-HR STORM

SYNTHETIC STORM VALUES FROM NOAA ATLAS 2 VOL VII

NO DEPTH AREA REDUCTION

NO TRANSMISSION LOSSES

10 IO OUTPUT CONTROL VARIABLES

IPRNT 3 PRINT CONTROL

IPLOT 0 PLOT CONTROL

QSCAL 0. HYDROGRAPH PLOT SCALE

IT HYDROGRAPH TIME DATA

NMIN 1 MINUTES IN COMPUTATION INTERVAL

IDATE 10 STARTING DATE

ITIME $\quad 0000$ STARTING TIME

NQ 288 NUMBER OF HYDROGRAPH ORDINATES

NDDATE 10 ENDING DATE

NDTIME 0447 ENDING TIME

ICENT 19 CENTURY MARK

COMPUTATION INTERVAL .02 HOURS

TOTAL TIME BASE 4.78 HOURS

ENGLISH UNITS

DRAINAGE AREA SQUARE MILES

PRECIPITATION DEPTH INCHES

LENGTH, ELEVATION FEET

FLOW CUBIC FEET PER SECOND

STORAGE VOLUME ACRE-FEET

SURFACE AREA ACRES

TEMPERATURE DEGREES FAHRENHEIT

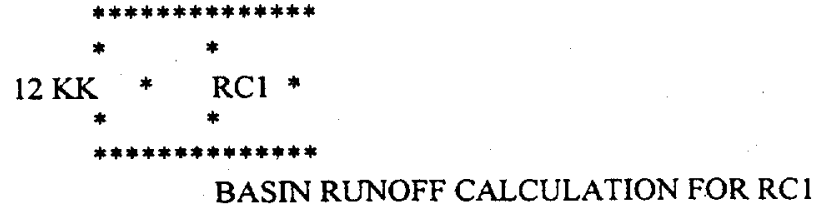


SUBBASIN RUNOFF DATA

$15 \mathrm{BA}$

SUBBASIN CHARACTERISTICS

TAREA $\quad .79$ SUBBASIN AREA

PRECIPITATION DATA
BN-0905 (08/29)

alysis Calc. \#: $A / C-00022.454-C-146$ Prepared By: JMD

Checked By: UY

Rev.\# Page 23 of 25

$13 \mathrm{PH}$

DEPTHS FOR 0-PERCENT HYPOTHETICAL STORM

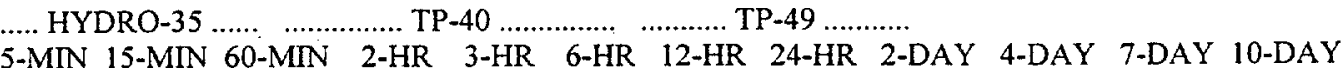

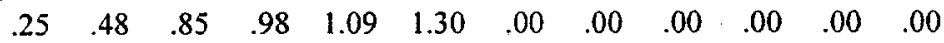

STORM AREA $=.79$

16 LS SCS LOSS RATE

STRTL $\quad .67$ INITIAL ABSTRACTION

CRVNBR 75.00 CURVE NUMBER

RTIMP $\quad .00$ PERCENT IMPERVIOUS AREA

17 UD SCS DIMENSIONLESS UNITGRAPH

TLAG $\quad .85 \mathrm{LAG}$

$\begin{array}{llll}\text { IALUE EXCEEDS TABLE IN LOGLOG } & .01667 \quad .01667 & 6.00000\end{array}$

UNIT HYDROGRAPH

257 END-OF-PERIOD ORDINATES

$\begin{array}{lllllllll}3 . & 5 . & 8 . & 10 . & 13 . & 18 . & 25 . & 31 . & 37 .\end{array} 4$.

50. 58. $65 . \quad 73 . \quad 81.90 . \quad 101 . \quad 111 . \quad 121 . \quad 132$.

143. 157. 171. 185. 199. 213. 229. $246.262 . \quad 279$.

295. 309. 322. 336. 350. 364. 374. 383. 393.402.

412. 418. 423. 428. 433.: 438. 441. 442. 442. 443.

444. 444. 443. 442. 442. 441. 438. 433. 428. 423.

418. 412. 406. 400. 394. 388. 382. 375. 368.361.

354. 347. 339. 330. 322. 313. 304. 295. 284.274.

263. 253. 244. 235. 227. 218. 209. 202. 196. 190

184. 178. 172. 167. 161. 156. $151.146 .142 . \quad 137$.

133. 129. 124. 121. 118 . 115. 112. 109. 106. 102.

$\begin{array}{llllllllll}99 . & 96 . & 93 . & 90 . & 88 . & 85 . & 82 . & 80 . & 77 . & 75 .\end{array}$

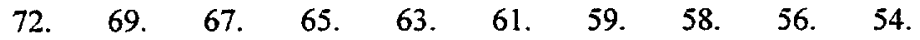

53. $\quad 51.49 .47 .46 .45 .44 .42 .41 .40$.

38. $37 . \quad 36 . \quad 34 . \quad 33 . \quad 33 . \quad 32 . \quad 31 . \quad 30 . \quad 29$.

28. 27. 26.25 .24 .23 .23 .22 .22$.

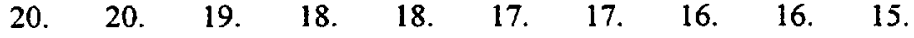

15. 14. 14. 13. 13.13 .12 .12 .12 .11$.

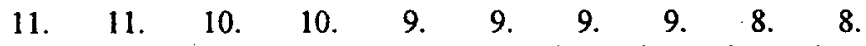

$\begin{array}{llllllllll}8 . & 8 . & 7 . & 7 . & 7 . & 7 . & 6 . & 6 . & 6 . & 6 .\end{array}$

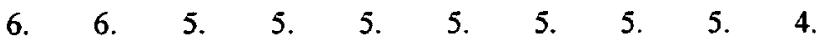

4. 4. 4.4 4. 4.4 4. 4.4 4. 4.4 .

3. 3. 3. 3. 3. 3. $3 . \quad 3 . \quad 3.2$.

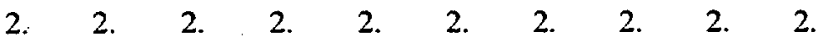

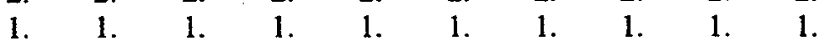

1. $\quad 0.0$ 0. 0.0 . 0.0 .

HYDROGRAPH AT STATION RC1

TOTAL RAINFALL $=1.22$, TOTAL LOSS $=1.14$, TOTAL EXCESS $=\quad .08$

PEAK FLOW TIME MAXIMUM AVERAGE FLOW

6-HR 24-HR 72-HR 4.78-HR

(CFS) (HR)

19. (CFS)

(INCHES) $\quad .056 \quad .056, .056 \quad .056$

CUMULATIVE AREA $=.79$ SQ MI 


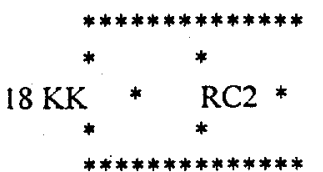

BASIN RUNOFF CALCULATION FOR RC2

SUBBASIN RUNOFF DATA

20 BA SUBBASIN CHARACTERISTICS

TAREA $\quad .42$ SUBBASIN AREA

\section{PRECIPITATION DATA}

$13 \mathrm{PH}$

..... HYDRO-35

DEPTHS FOR 0-PERCENT HYPOTHETICAL STORM

5-MIN 15-MIN 60-MIN 2-HR 3-HR 6-HR 12-HR 24-HR 2-DAY 4-DAY 7-DAY 10-DAY

$\begin{array}{llllllllllll}.25 & .48 & .85 & .98 & 1.09 & 1.30 & .00 & .00 & .00 & .00 & .00 & .00\end{array}$

STORM AREA $=.42$

$21 \mathrm{LS}$

SCS LOSS RATE

STRTL $\quad .67$ INITIAL ABSTRACTION

CRVNBR 75.00 CURVE NUMBER

RTIMP $\quad .00$ PERCENT IMPERVIOUS AREA

22 UD

SCS DIMENSIONLESS UNITGRAPH

TLAG $\quad .95$ LAG

${ }^{\prime}$ ALUE EXCEEDS TABLE IN LOGLOG $\quad .01667 \quad .01667 \quad 6.00000$

UNIT HYDROGRAPH

287 END-OF-PERIOD ORDINATES

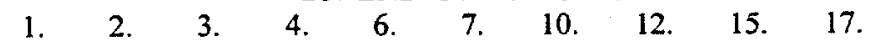

20. 23. $26.49 . \quad 33 . \quad 36.39 .44 .48 .52$.

$\begin{array}{llllllllll}57 . & 61 . & 66 . & 72 . & 77 . & 83 . & 89 . & 95 . & 101 . & 108 .\end{array}$

115. 122 . 129. $136.143 . \quad 149 . \quad 154 . \quad 160.166 .172$.

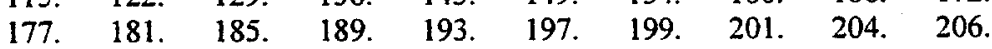

208. 210. 210. 210. $211 . \quad 211 . \quad 212 . \quad 212 . \quad 211 . \quad 211$.

210 . 210. 210. 208. $206 . \quad 204 . \quad 201 . \quad 199 . \quad 197 . \quad 194$.

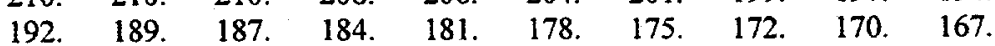

163. 160. 156. 152. 149. 145. 141. 136. 132.127.

123. 119. 115. 111. 108. 104. 100. 97. 94. 92.

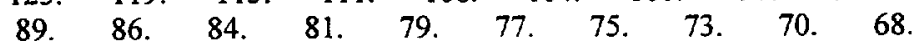

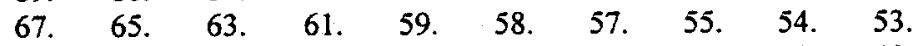

51. $50.49 . \quad 47 . \quad 46 . \quad 44 . \quad 43 . \quad 42 . \quad 41.40$.

$39.38 .37 . \quad 36 . \quad 34 . \quad 33 . \quad 32 . \quad 31 . \quad 30.30$.

$29.28 .27 .27 . \quad 26 . \quad 25 . \quad 24.24 . \quad 23.22$.

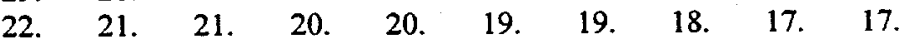

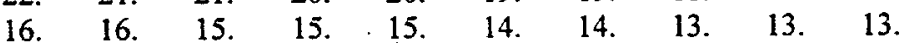

12. 12. 12. 11. 11. 11. 10.40 .10 .10$.

$\begin{array}{llllllllll}9 . & 9 . & 9 . & 8 . & 8 . & 8 . & 8 . & 8 . & 7 . & 7 .\end{array}$

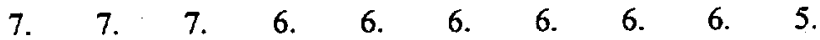

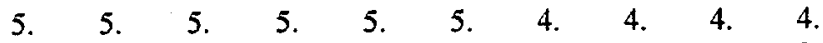

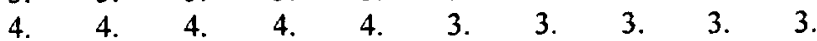

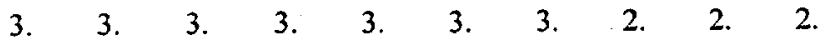

$\begin{array}{lllllllll}2 . & 2 . & 2 . & 2 . & 2 . & 2 . & 2 . & 2 . & 2 .\end{array}$

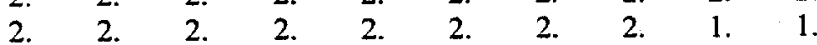

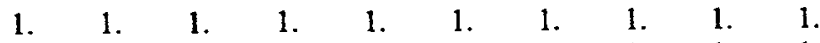

1. 1.1 .1 .1 .1 .1 .1 .1$.

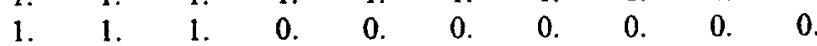

$\begin{array}{lllllll}1 . & 0 . & 0 . & 0 . & 0 . & 0 . & 0 .\end{array}$ 
TOTAL RAINFALL $=1.23$, TOTAL LOSS $=1.15$, TOTAL EXCESS $=.08$

JEAK FLOW TIME MAXIMUM AVERAGE FLOW (CFS) (HR)

10. 3.82 on-0805 (0asos) Becmel nevaga

Analysis Calc. \#: $A / c-00022,454-C=$

Prepared By: JMO

Checked By: UY

Rev.\#

Page 25 of 2

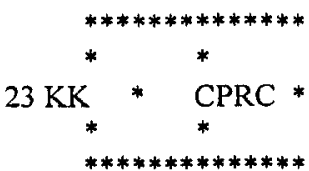

COMBINE FLOW FROM RC1 WITH FLOW FROM RC2 AT CULVERT

$25 \mathrm{HC}$ HYDROGRAPH COMBINATION

ICOMP 2 NUMBER OF HYDROGRAPHS TO COMBINE

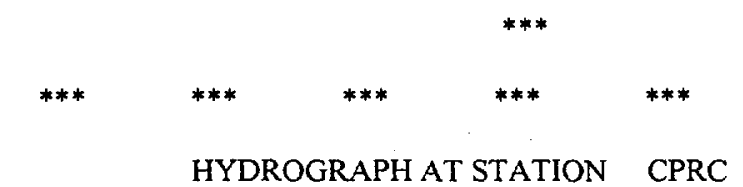

PEAK FLOW TIME MAXIMUM AVERAGE FLOW

(CFS) (HR)

$$
\text { 6-HR 24-HR 72-HR 4.78-HR }
$$

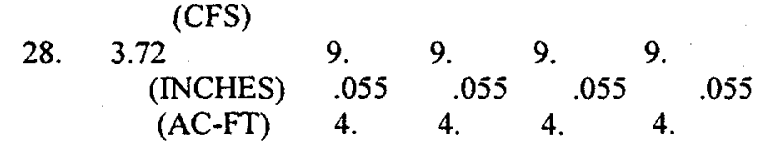

CUMULATIVE AREA $=1.21 \mathrm{SQ} \mathrm{MI}$

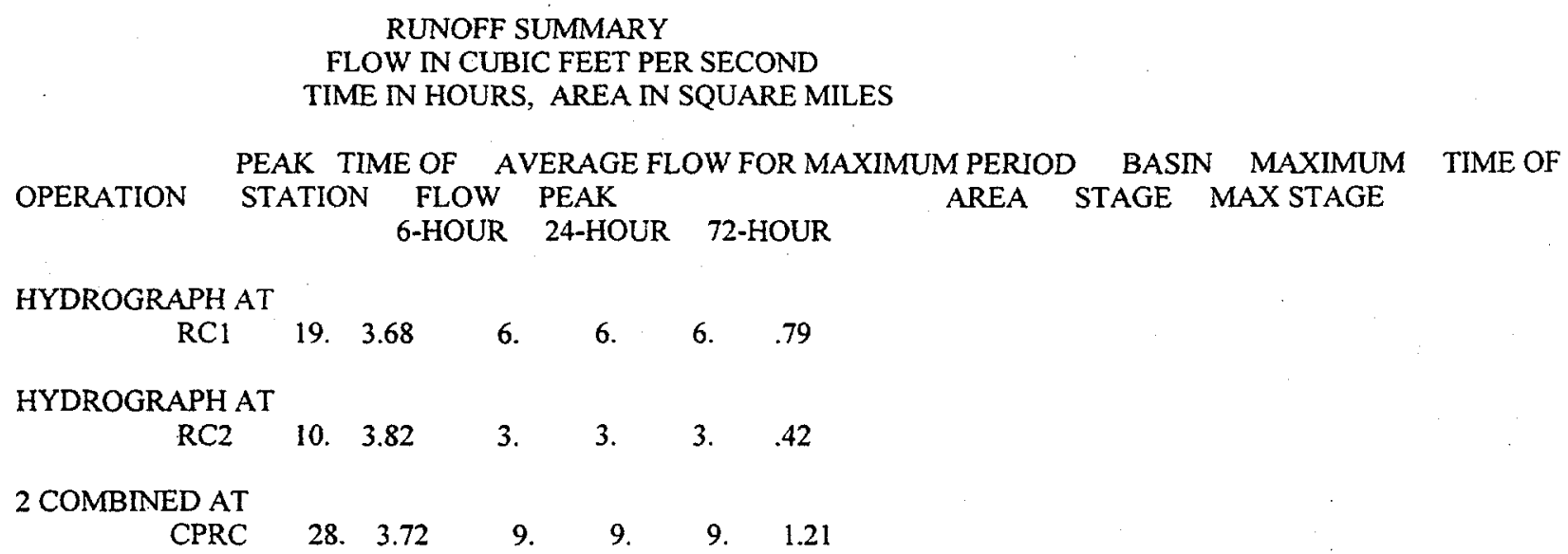




\section{APPENDIX C}

NDEP CLOSURE PLAN COMMENT RESPONSE 

DOCUMENT REVIEW SHEET

1. Document Title/Number: CORRECTIVE ACTION PLAN FOR CORRECTIVE ACTION UNIT 407: ROLLER COASTER RADSAFE AREA, TONOPAH TEST RANGE, NEVADA

2. Document Date: May 2000

3. Revision Number: 0

4. Originator/Organization: Bechtel Nevada Environmental Restoration

5. Responsible: Thomas Fitzmaurice

6. Date Comments Due:

7. Review Criteria:

6. Reviewer/Organization: Nevada Department of Environmental Protection

\begin{tabular}{|c|c|c|c|c|}
\hline $\begin{array}{c}10 . \\
\text { Comment } \\
\text { Number/ } \\
\text { Location }\end{array}$ & $\begin{array}{l}11 . \\
\text { Type }^{a}\end{array}$ & 12. Comment & 13. Comment Response & $\begin{array}{l}14 . \\
\text { Accept }\end{array}$ \\
\hline $\begin{array}{l}1 . \\
\text { Appendix } \\
\text { A }\end{array}$ & M & $\begin{array}{l}\text { Appendix A is missing engineering } \\
\text { specifications and/or drawings } \\
\text { (Appendix A1); a sampling and } \\
\text { analysis plan (Appendix A2); and } \\
\text { Project Organization (Appendix } \\
\text { A3). These requirements were } \\
\text { agreed to in the template for the } \\
\text { CAP which was approved on } \\
8 / 21 / 98 \text {. }\end{array}$ & $\begin{array}{l}\text { Appendix A was sent out under a different cover } \\
\text { letter. Subsequent telephone communication with } \\
\text { NDEP indicated that the engineering specifications } \\
\text { were received and a confirmaton letter was issued } \\
\text { to DOE. Appendix A was renamed Appendix A-1 } \\
\text { and is included in the final CAP. Appendix A-3 } \\
\text { has been added to the final CAP. Appendix A-2 } \\
\text { has been omitted because no physical samples will } \\
\text { be collected for analysis. }\end{array}$ & Yes \\
\hline
\end{tabular}




\begin{tabular}{||l|l|l|l|l||}
\hline $\begin{array}{c}10 . \\
\begin{array}{c}\text { Comment } \\
\text { Number/ } \\
\text { Location }\end{array}\end{array}$ & $\begin{array}{l}\text { 11. } \\
\text { Type }^{\mathrm{a}}\end{array}$ & 12. Comment & 13. Comment Response & $\begin{array}{l}\text { 14. } \\
\text { Accept }\end{array}$ \\
\hline \hline $\begin{array}{l}\text { Appendix } \\
\text { A. }\end{array}$ & $\mathrm{M}$ & $\begin{array}{l}\text { “..The SITA Plan and engineering } \\
\text { drawings can be found in Appendix } \\
\text { A..." Appendix A was empty. }\end{array}$ & See response to comment 1. & Yes \\
\hline
\end{tabular}




\section{DISTRIBUTION LIST}




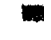

$=$

THIS PAGE LEFT INTENTIONALLY BLANK

a

.

-

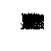




\section{DISTRIBUTION LIST}

*Provide copy of initial distribution or Revision 0 ; remainder of list gets Revision 0 if approved without changes. The entire list receives Revision 1, if issued.

\section{Nevada Division of Environmental Protection}

Paul Liebendorfer

Bureau of Federal Facilities

Division of Environmental Protection

333 W. Nye Lane, Room 13B

Carson City, NV 89706-0866

Mike McKinnon

Bureau of Federal Facilities

Division of Environmental Protection

Sawyer State Building

555 E. Washington, Suite 4300

Las Vegas, NV 89101-1049

\section{U.S. Department of Energy}

Janet Appenzeller-Wing

Environmental Restoration Division

U.S. Department of Energy, Nevada Operations Office

P.O. Box $98518 \mathrm{M} / \mathrm{S} 505$

Las Vegas, NV 89193-8518

Kevin Cabble

Environmental Restoration Division

U.S. Department of Energy, Nevada Operations Office

P.O. Box $98518 \mathrm{M} / \mathrm{S} 505$

Las Vegas, NV 89193-8518

Sabrina Lawrence

Environmental Restoration Division

U.S. Department of Energy, Nevada Operations Office

P.O. Box $98518 \mathrm{M} / \mathrm{S} 505$

Las Vegas, NV 89193-8518
2(Controlled)*

1(Controlled)*

1(Uncontrolled)*

1(Uncontrolled)*

1(Controlled)* 


\section{DISTRIBUTION LIST (Continued)}

\section{U.S. Department of Energy (continued)}

U.S. Department of Energy

Office of Scientific and Technical Information

P.O. Box 62

Oak Ridge, TN 37831-0062

U.S. Department of Energy

Nevada Operations Office

Technical Information Resource Center

P.O. Box 98518 , M/S 505

Las Vegas, NV 89193-8521

Manager, Southern Nevada

FFACO Public Reading Room

P.O. Box $98521 \mathrm{M} / \mathrm{S}$ NLV040

Las Vegas, NV 89193-8521

Manager, Northern Nevada

FFACO Public Reading Room

Nevada State Library and Archives Federal Publications

100 North Stewart Street

Carson City, NV 89701-4285
1(Uncontrolled, electronic copy)

1(Uncontrolled)

1(Controlled) \&

1(Uncontrolled)

1(Uncontrolled)

\section{Bechtel Nevada}

Correspondence Control

1(Uncontrolled)*

Bechtel Nevada

P.O. Box $98521 \mathrm{M} / \mathrm{S}$ NLV008

Las Vegas, NV 89193-8521

Environmental Management Library

1(Uncontrolled)*

Bechtel Nevada

P.O. Box 98521, M/S NLV080

Las Vegas, NV 89193-8521 


\section{DISTRIBUTION LIST (Continued)}

\section{Bechtel Nevada (continued)}

David Cowser

1(Uncontrolled)*

Bechtel Nevada

P.O. Box $98521 \mathrm{M} / \mathrm{S}$ NLV082

Las Vegas, NV 89193-8521

Ann Heidema

1(Uncontrolled)*

Bechtel Nevada

P.O. Box $98521 \mathrm{M} / \mathrm{S}$ NLV022

Las Vegas, NV 89193-8521

Thomas Fitzmaurice

1(Uncontrolled)*

Bechtel Nevada

P.O. Box $98521 \mathrm{M} / \mathrm{S}$ NTS306

Las Vegas, NV 89193-8521

Dennis Gustafson

1(Uncontrolled)*

Bechtel Nevada

P.O. Box $98521 \mathrm{M} / \mathrm{S}$ NTS306

Las Vegas, NV 89193-8521.

Nathaneil Jackson

1(Uncontrolled)*

Bechtel Nevada

P.O. Box $98521 \mathrm{M} / \mathrm{S}$ NLV085

Las Vegas, NV 89193-8521

Jerrel Nelsen

1(Uncontrolled)*

Bechtel Nevada

P.O. Box $98521 \mathrm{M} / \mathrm{S}$ NTS306

Las Vegas, NV 89193-8521

Wayne Johnson

1(Uncontrolled)*

Bechtel Nevada

P.O. Box $98521 \mathrm{M} / \mathrm{S}$ NTS306

Las Vegas, NV 89193-8521 


\section{DISTRIBUTION LIST (Continued)}

\section{Bechtel Nevada (Continued)}

Steve Nacht

1 (Uncontrolled)*

Bechtel Nevada

P.O. Box $98521 \mathrm{M} / \mathrm{S}$ NTS306

Las Vegas, NV 89193-8521

\section{IT Corporation}

Brad Jackson

2 (Uncontrolled)*

IT Corporation

P.O. Box 93838

Las Vegas, NV 89193-8521

Jeff Johnson

1 (Uncontrolled)*

IT Corporation

P.O. Box 93838

Las Vegas, NV 89193-8521

IT FFACO Support Office

1 (Uncontrolled)*

IT Corporation

P.O. Box 93838

Las Vegas, NV 89193-8521

\section{U.S. Air Force}

Gerald Carpenter

U.S. Air Force DOE Liason Office

DOE/Nevada Operations Office

P.O. Box 98518, M/S 505

Las Vegas, NV 89193-8518 